一般演題 口演抄録 



\section{くも膜下出血に関連した脳梁膨大部DWI 高信号病変の出現についての検討}

\author{
川崎医科大学 脳神経外科 \\ ○井 宏行、松原 俊二、小川祐佳里、
佐藤 昂平、平井 聡、高井 洋樹、
石原 学、原 慶次郎、宇野 昌明
}

【背景・目的】も膜下出血 $(\mathrm{SAH})$ 症例において、経 過中に拡散強調画像 (DWI) で脳梁膨大部に可逆性 の高信号病変を認めることがあるが、その出現頻度 や臨床所見との関連は不明である。この病態につい て自験例を検討した。

【対象・方法】2009年4月から2016年6月までに当院 で手術を行ったSAH患者264例について、脳梁膨大 部DWI高信号病変の有無を調べた。また、この病 変と他の因子との関連を調べた。

【結果】脳梁膨大部DWI高信号病変は33例 (12.5\%)に 認めた。発症から脳梁膨大部病変検出までの期間は 平均 6.3 日 $(0$ 20)であった。Day0に認めたものは4

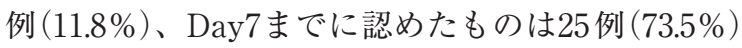
であった。術後に認めたものが 25 例 $(73.5 \%)$ と多数 であり、術前に認めていたものは、待機手術例を除 けば5例 $(15.1 \%)$ と少数であった。病変は限局性の 小さなタイプ(平均最大径 $10 . \mathrm{mm}$ ) と、脳室に沿っ た進展を示すタイプに大別できた。病変の消失を確 認できた時期はSAH発症から平均 35.7 日 $(9 \sim 78)$ で あった。病変 $(+)$ 群と病変 $(-)$ 群を比較した。病変 (+) 群では、H\&K重症例が多く $(\mathrm{p}=0.022) 、$ Fisher 分類で血腫量が多かった $(\mathrm{p}=0.008)$ 。コイル塞栓術 を施行した例が多く $(p=0.023)$ 、経過中に正常圧水 頭症を発症した例が多かった $(\mathrm{p}=0.0002)$ 。また、退 院時mRSが有意に悪かった $(p=0.002)$ 。動脈瘤の大 きさや部位、症候性スパズム発生とは関連がなかっ た。

【考察・結論】SAHに関連した脳梁膨大部病変は、 発症直後や術前に認めることは少なく、出現まで数 日の期間がかかり、1か月程度で消失すると推測さ れた。病態の本質は不明であるが、重症例、コイル 塞栓術施行例で出現率が高く、経過中の正常圧水頭 症発生、微小脳循環不全との関連が示唆された。

\section{CT perfusionによるくも膜下出血後の脳 血管攣縮の評価}

奈良県立医科大学 脳神経外科

$\begin{array}{cccc}\text { ○尾本 } & \text { 幸治、中川 } & \text { 一郎、山田 } & \text { 修一、 } \\ \text { 横山 昇平、森崎 } & \text { 雄大、輪島 } \text { 大介、 } \\ \text { 西村 文彦、横田 } & \text { 浩、本山 } & \text { 靖、 } \\ \text { 朴 永銖、中瀬 裕之 } & & \end{array}$

【目的】脳動脈瘤破裂によるくも膜下出血 (SAH) 術 後に生じる脳血管攣縮による遅発性神経脱落症状は 重大な予後悪化因子であり、その早期診断と適切 な予防が周術期管理に求められる。近年、虚血性 脳卒中の診断や治療効果予測のためにCT perfusion (CTP) の有用性が確立しつつある。今回我々は SAH術後の脳血管攣縮に対して血管内治療を行っ た症例において治療前のCTPの評価及びその有用性 について後方視的に検討した。

【方法】2014年1月から 2016 年 12 月までに脳動脈瘤 破裂によるSAHに対して外科手術もしくは血管内 治療を行い、術後CTP評価を行った 113 例 (男性 34 例、平均年齢 66 歳)を対象とした。周術期管理は当 科ガイドラインに沿って行い、Day 5-9にCTPにて 脳血流を評価し、DSAにて症候性脳血管攣縮もし くは無症候性でも $50 \%$ 以上の狭窄に対して塩酸ファ スジルの動注療法を行った。塩酸ファスジルの動 注は内頚動脈及び椎骨動脈から行い、動注後に標 的血管の拡張を確認した。CTPはTTPを用いた定 性的評価および側脳室前角のスライスにて左右8か 所の皮質領域にROIとする定量的評価 $(\mathrm{CBF} 、 \mathrm{CBV}$ 、 MTT)とした。

【結果】塩酸ファスジルの動注療法を行った症例は14 例 (男性 5例、平均年齢59歳)であり全体の $12 \%$ で あった。14例全例でTTP延長部位を視覚的に確認 しえた。また脳梗塞発生例ではCBFの低下が認めら れた。

【結論】術後CTPによる脳血流評価はダイナミックに 変化する脳血管攣縮の病態把握に有用である可能性 が示唆された。 


\section{開頭手術アプローチによる高次脳機能へ の影響}

${ }^{1}$ 愛媛大学 医学部 地域医療再生学、 ${ }^{2}$ 愛媛大学 医 学部 脳神経外科学

○久門 良明 ${ }^{1} 、$ 松本 調 ${ }^{2}$ 、渡邊 英昭 ${ }^{2}$ 、 國枝 武治 ${ }^{2}$

【目的】開頭手術による高次脳機能への影響をアプ ローチ別に検討した。

【方法】未破裂脳動脈瘤開頭術の前後にWAIS-Rを 行った106例を対象とした。アプローチは左・右 pterional approach (PA) : 30・64、interhemispheric approach (IHA) : 12で、瘤部位は内頝動脈 : 31 、 中大脳動脈 $(\mathrm{MCA}): 33$ 、前大脳動脈 (ACA) : 31、 脳底動脈 : 1 、多発性 : 10 例であった。個々の例で は、全IQが4点以上減少を悪化、4点以上増加を改善、 それ以外を不変と評価した。言語性下位検査は 1 : 知識、 3 : 数唱、 $5:$ 単語、 7 : 算数、 $9:$ 理解、 11 : 類似、動作性下位検査は 2 : 絵画完成、 4 : 絵画配列、 6 : 積木模様、8：組合せ、10：符号である。脳血流 (133Xe-SPECT) は62例で測定した。

【結果】1) 術前と術後の言語性、動作性、全 IQは、 左PAでは 97.1 と97.2、98.9と102.7*、98.1と99.8、右 PAでは100.6と 102.9*、102と104.1*、101.9と103.4、 IHAでは97.8と101.8*、99.6と104.6、99.2と103.7*で 増加した $(*$ 有意)。脳血流は右PA (34例)では術側 ACA と前方MCA域で、左PA（21例)では術側前方 MCA領域で優位に低下した。2) 各アプローチで全 IQの悪化、不変、改善は、左PAでは7、12、11例、 右PAでは15、21、28例、IHAでは1、4、7例であった。 脳血流は不変例や改善例でも優位に低下した。3）下 位検査は、左PA悪化例では5、7が減少、改善例で は2、4、6、8が増加し、右PA悪化例では7、9、2、4、

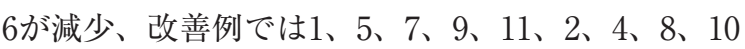
が増加した。IHA改善例では1、9、11、8が増加した。 【結論】各アプローチとも術後何れかのIQが改善した が、個別ではアプローチの違いにより下位検査の変 化が異なり、手術操作が影響していると推測された。 脳血流変化との関連は認められなかった。

\section{クモ膜下出血後慢性期における白質神経 組織萎縮の臨床的特徵と意義}

岐阜大学 医学部 脳神経外科

○江頭 裕介、榎本由貴子、船津奈保子、 山内 圭太、岩間亭

【背景】種々の脳卒中病型において近年白質神経傷害 は特に高次脳機能障害との関連から注目を集めてい るが、これまで臨床例においてクモ膜下出血 (SAH) 後の白質傷害を論じた報告はない。今回われわれは、 $\mathrm{SAH}$ 後慢性期の白質傷害をMRI所見より検索した。 【対象と方法】2014年より当科でコイル塞栓術にて破 裂脳動脈瘤の根治を行ったSAH症例のうち、日常 生活に復帰でき(3 ケ月後mRS 0-2)、かつMRIにて 治療後のフォローアップが可能であった連続 15 症 例 (平均年齢 62.5 歳、女性 10 例) を対象とし、 $\mathrm{SAH}$ 後亜急性期 (3 週間) おょび慢性期 (6r月) 後での脳 梁膝部の厚みを定量的に評価し、脳梁組織の萎縮お よび関連する臨床的背景因子について検討した。

【結果】SAH発症後慢性期の脳梁膝部の厚みは亜 急性期と比較し有意に減少しており、白質神経組 織の萎縮と考えられた $(8.16$ vs. $8.89 \mathrm{~mm} ; \mathrm{p}<0.05)$ 。 $\mathrm{SAH}$ 軽症例 (WFNS grades $1 、 2$ )、後方循環脳動脈 瘤症例ではこの期間で有意な白質神経組織萎縮が 見られなかったのに対して、重症例(WFNS grades 4、5) および前方循環動脈瘤症例において有意な 白質神経組織の萎縮が見られた(それぞれ $8.00 \mathrm{vs.}$ $8.80 \mathrm{~mm} ; \mathrm{p}<0.05 、 7.46$ vs. $8.89 \mathrm{~mm} ; \mathrm{p}<0.01)$ 。ま た、軽度後遺症例 (発症 3 ケ月後mRS 1 または2)に おいて白質神経組織萎縮は顕著であった (7.32 vs. $9.17 \mathrm{~mm} ; \mathrm{p}<0.01) 。$

【結語】臨床例において、SAH後慢性期の白質神経萎 縮が確認され、重症例、前方循環動脈瘤症例でより 有意な萎縮が見られることが示された。また、日常 生活復帰例に残存する軽度後遺症に白質神経傷害が 関与している可能性が示唆された。 


\section{成人虚血型もやもや病の手術成績と長期 予後}

岡山大学大学院 脳神経外科

○菱川 朋人、平松 匡文、杉生 憲志、 伊達 勲

【目的】当科に扔ける成人虚血型もやもや病の手術成 績と長期予後をまとめ、血行再建術の効果と問題点 を検証した。

【方法】1989年以降当科で外科治療を行った成人虚 血型もやもや病連続 49 例 62 側を対象とした。外科 治療はMCA 領域の血行再建術を行い、観察期間は 中央值 (力月) で 48 力月。術前及び最新の modified Rankin Scale (mRS)、周術期症候性脳卒中、慢性 期症候性脳卒中の発生について検討した。更にmRS 悪化例においてその要因について検証した。

【結果】発症年齢は36歳 (中央值)、男性 15例、女性 34 例で、TIA発症が30例、脳梗塞発症が19例であっ た。外科治療は直接バイパス 5 側、間接バイパス 6 側、複合バイパス 51 側であった。術前 $\mathrm{mRS}$ は中央 值 (IQR) で0 (0-1)、最新mRSは0 (0-1)で両者で有意 差を認めなかった $(\mathrm{P}=0.24)$ 。 $\mathrm{PCA}$ 病変の合併を 15 例 (31\%) に、周術期症候性脳卒中を 10 例 (20\%)（脳 梗塞 9 例、脳出血 1 例) に、慢性期症候性脳卒中を 3 例 (6\%) (脳梗塞 2 例、脳出血 1 例) に認めた。術前後 でmRS悪化を 9 例 $(18 \%)$ に認め、悪化例の最新 $\mathrm{mRS}$ は2（1-3）であった。mRS悪化例 (9例) と $\mathrm{mRS}$ 不変・ 改善例 $(40$ 例) を比較するとICA病変の重症度 $(\mathrm{P}=$ $0.6) 、 \mathrm{PCA}$ 病変の合併頻度 $(22 \%$ vs $33 \% 、 \mathrm{P}=0.7)$ は有意差がないものの、周術期症候性脳卒中の発生 (78\% vs $8 \% 、 \mathrm{P}<0.0001)$ 、慢性期症候性脳卒中の 発生 $(33 \%$ vs $0 \% 、 P=0.005)$ はRRS悪化に有意に 関与していた。

【結論】成人虚血型もやもや病に対する血行再建術は 機能予後維持に有効である。血行再建術介入後の $\mathrm{mRS}$ 悪化には周術期脳卒中 (特に脳梗塞) と慢性期 脳卒中が有意に関与し、これらの予防が長期成績の 改善に寄与するものと思われる。

\section{もやもや病の頭痛と血行再建}

${ }^{1}$ 名古屋市立大学大学院 医学研究科 脳神経外科. 医学医療情報管理学、 ${ }^{2}$ 名古屋市立大学大学院 - 医 学研究科・脳神経外科

$\bigcirc$ 片野 広之 ${ }^{1}$ 、西川 祐介 ${ }^{2}$ 、山田 紘史 ${ }^{2}$ 、 間瀬 光人 ${ }^{2}$

【背景】もやもや病患者の頭痛は日常よく遭遇するが、 手術との関連など明らかでない点も多い。

【方法】当院通院中のもやもや病患者 84 名について、 頭痛の有無、特徴、発症型、手術の有無などを後方 視的に検討した。

【結果】男性 : 女性 $=27: 57$ 、平均年齢 $46 \pm 17$ 歳、平 均観察期間 $5.8 \pm 6.9$ 年、手術施行例 40/84 (47.6\%)、 未施行例 (外来経過観察) 44/84 (52.4\%)。手術は直 接単独または間接血行再建併用 (STA-MCA吻合術 $+\mathrm{EMS}) 35$ 例、間接血行再建のみ $(\mathrm{EMS} 、 \mathrm{EDAS}) 5$ 例。 出血型 23 例、虚血型 47 例、無症候型 14 例で、うち 再発を 12 例(出血による死亡 2 例)に認めた。頭痛 の訴えは41/84例 $(48.8 \%)$ に認め、うち両側もや 37 、 片側もや4例、また虚血型23、出血型 8 、虚血+出血 型2、無症候型 8 であった。手術未施行の外来通院 患者では20名に、手術施行患者では術前に8例の頭 痛の訴えが認められたが、術後外来での経過中には 19例の患者が頭痛を訴えた。MRAにてバイパス開 存はいずれも良好であった。頭痛側は明らかな傾向 はなく、術前の症状、症候や $\mathrm{rCBF}$ とは異なる場合 もあった。鎮痛剂での制御が容易な軽度頭痛が約半 数 $(51.2 \%)$ であった一方、中等度以上の頭痛も約半 数認めた。

【結語】もやもや病患者では血行再建術後に頭痛の訴 えが多い傾向が見られた。再発例の中に頭痛の訴え が続いていたものもあり、注意深い経過観察が必要 と考えられた。 


\section{もやもや病の初回手術不応例に対する repeat bypassの効果}

\author{
${ }^{1}$ 富山大学 医学部 脳神経外科、 ${ }^{2}$ 北海道大学医学 \\ 部脳神経外科
}

○内野 晴登 ${ }^{1,2}$ 、山本 修輔 ${ }^{1}$ 、柏崎 大奈 $^{1}$ 、
秋岡 直樹 ${ }^{1}$ 、宝金 清博 ${ }^{2}$ 、黑田 敏 ${ }^{1}$

【背景と目的】もやもや病では虚血性および出血性脳 卒中の発症予防に血行再建術が有効で唯一の治療法 である。大半は初回手術が有効性を示すが、初回手 術の効果が不十分な例や、初回手術後に後大脳動脈 領域の虚血症状を呈する例では、追加手術(repeat bypass)が必要になる。今回、われわれは、もやも や病に対して実施したrepeat bypassの適応、術式、 長期効果などに関して検討したので報告する。

【方法】著者らが過去 20 年において repeat bypassを 実施した全 18 名 20 半球を対象とした (平均 28.5 歳、 1-69歳)。このうち10半球は他院で実施された血行 再建術 (大部分はEDASまたはEMS)の効果が不十分 であった症例 (Group A)、残り10半球は初回手術後 に後大脳動脈の狭窄進行を認めた症例 (Group B) で あった。初回手術後にTIA、脳梗塞、頭蓋内出血や 脳循環不全をきたした場合にrepeat bypassを考虑 した。Group Aでは直接 (STA-MCA) +間接バイパ 又術もしくは間接バイパス術を同側の前方循環領域 へ追加した。Group Bでは直接 (OA-PCA/MCA)+ 間接バイパス術もしくは間接バイパス術を後方循環 領域へ追加した。これらのrepeat bypassでは、ド ナーやレシピエントの状態、脳循環不全領域を詳細 に検討したうえで、術式および開頭野を決定した。 【結果】全例において術後合併症は認めず、TIAは術 後 6 ケ月以内に消失もしくは改善した。また手術領 域では良好な血管新生および脳循環不全の改善を認 めた。さらにrepeat bypass後平均 3.2 年の経過観察 期間において、19名中 1 名 (5.2\%)が3年後に脳内出 血で死亡した以外は脳卒中の再発を認めていない。 【結論】もやもや病に扔いて初回手術不応例に対する repeat bypassは、安全かつ脳卒中再発予防、脳循 環不全の改善において非常に有効であった。また最 良の効果を得るには術前の綿密な手術計画が肝要で ある。

\section{もやもや病患者の血液単核球の細胞特性}

${ }^{1}$ 東海大学 医学部 内科学系 神経内科、 ${ }^{2}$ 東海大学 医学部 基盤診療学系 再生医療科学、 ${ }^{3}$ 東海大学 医学部 外科学系 脳神経外科

中山 平 ${ }^{1}$ 、永田栄一郎 ${ }^{1} 、$ 増田 治史 $^{2}$ 、
小原さ抢 ${ }^{1}$ 、藤井奈津子 ${ }^{1}$ 、湯澤 公子 $^{1}$ 、
長田 貴洋 ${ }^{3}$ 、反町 隆俊 ${ }^{3}$ 、松前 光紀 $^{3}$ 、
浅原 孝之 ${ }^{2}$ 、瀧澤 俊也 $^{1}$

【目的】もやもや病 (MMD) は進行性血管閉塞性障害 が起きる疾患であり、その原因として血管新生の異 常やEPCの異常などが報告されている。今回我々は、 サイトカインに関してEPCを含む単核球群に含まれ るサイトカインプロファイリングを測定し、さらに、 抗炎症・血管再生促進性培養下で培養したEPCを含 む単核球群(再生アソシエイト細胞)でのサイトカイ ンプロファイリングに関して健常者と比較検討した。 【対象・方法】MMD患者 $(\mathrm{n}=10)$ 掞よび年齢をマッチ させた健常者 $(\mathrm{n}=6)$ の末梢血より単核球 $(\mathrm{PB}-$ $\mathrm{MNCs}$ )を分離し、24時間培養した。さらにSCF、 TPO、Flt-3 ligand、VEGF、IL-6の5つの成長因子 を加元1週間培養 (Quality and quantity (QQ) 培養) した再生アソシエイト細胞を採取した。各培養上 清をサイトカイン測定した。また、マウス頸動脈 に添加し、血管側枝の形成を観察 (ring assay) し た。さらに $\mathrm{QQ}$ 培養前後での単核球群を Matrigel上 にHUVECを加えて新生血管の形成 (tube formation assay）を観察した。

【結果】MMD患者群と健常者群では、培養前のサ イトカインプロファイリングには有意な差は認め なかったが、QQ培養後では、MMDでLarge cellの 増加やIL-10の上昇がみられなかった。また、 ring assayではMMDの血管側枝新生が不良であり、 tube formation assayでは、MMDは健常者と比較して、 新生血管形成が悪く、また、血管破壊も早期より認 められた。

【結論】MMD患者の単核球群は、QQ培養による 抗炎症、血管再生促進環境下に打いて、健常者に 比較して炎症性の細胞特性を示した。この結果は、 MMDの病態として、局所微小血管における炎症環 境の存在㧍よび血液細胞群による血管再生機能の障 害を示唆する。 


\section{頭蓋内動眽狭窄の遺伝的要因－RNF213 遺伝子の全エクソン解析による検証一}

\author{
${ }^{1}$ 東京大学 医学部 脳神経外科、 ${ }^{2}$ 関東脳神経外科 \\ 病院、 ${ }^{3}$ 富士脳障害研究所附属病院

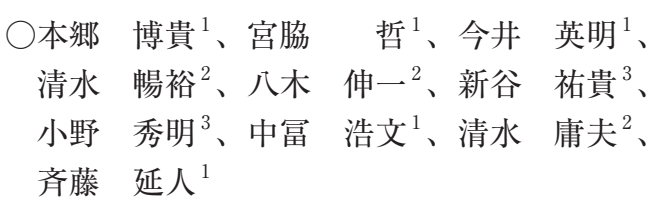

【背景】我々は近年、頭蓋内動脈硬化 (intracranial atherosclerosis : ICAS) とRNF213遺伝子上の missense変異c.14576G >A（p.R4859K）の強い関連を報 告してきた(Stroke 2012、2013)。RNF213はexon 数が69ある遺伝子であり、p.R4859K以外にICASと 関連する変異・多型が存在するか検証した。

【方法】東大病院および関東脳神経外科病院において ICAS症例 168例、control 141 例に対し同意を得て 採血を行いgenomic DNAサンプルを収集。次世代 シークエンサーを用いたtarget resequenceにより $R N F 213$ の全エクソン解析を行ない、ICAS群と対 照群の2 群間で関連解析を行った。

【結果】66の変異・多型が認められた (missense変異 39、silent変異27)。関連解析の結果、統計学的有 意差を認めた変異はp.R4859K以外にはp.A3517Vの みであった。p.A3517Vはcontrol群の頻度の方が高 く(ICAS 2/166、Control 9/132)、p.R4859K の み がICASに有意に関連した(ICAS 42/126、Control $/ 2 / 139: \mathrm{p}=6.07 \times 10-9)$ 。rare variantは 22 種、うち p.R4859K陰性例において15種認められた。RNF213 はもともともやもや病関連遺伝子として同定された 遺伝子であるが、この15種のrare variantの中に先 行文献においてもやもや病関連変異として報告され たものを 1 種類 $(\mathrm{p} . \mathrm{L} 2405 \mathrm{~F})$ 認めた。

【考察・結語】p.R4859K以外に統計学的に有意な疾 患関連遺伝子変異を認めず、RNF213 p.R4859Kの 重要性が再確認される結果となった。Rare variant の中にはICASとの関連を示唆するものも認められ、 RNF213に関連するICASはこれまでの報告よりも 多い可能性が示唆された。さらなる症例の蓄積と RNF213の機能解析が必要と考えられた。

\section{ラットー過性脳虚血モデルに対する細胞 治療：[18F] DPA-714 PETイメージン グを用いた神経免疫反応の評価}

${ }^{1}$ 北海道大学病院 臨床研究監理部、 ${ }^{2}$ 北海道大学 医学研究院 脳神経外科、 ${ }^{3}$ 福島県立医科大学 くしま国際医療科学センター 先端臨床研究セン ター、 ${ }^{4}$ 北海道大学 アイソトープ総合センター

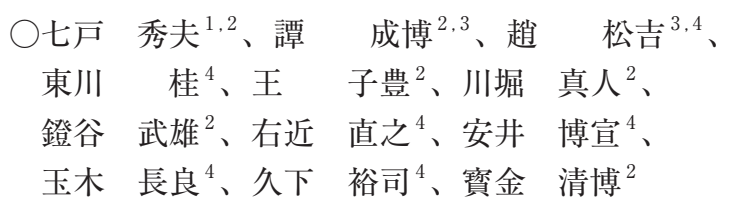

【目的】脳梗塞では急性期に炎症反応が惹起され、二次 的な障害を招くことが知られているが、骨髄間葉系幹 細胞 (MSC) を用いた細胞治療では、その治療機序に 関してimmunomodulation効果の重要性が指摘されつ つある。一方、神経炎症反応を画像化する試みとし て、 translocator protein (TSPO)リガンドである [18F] DPA-714をトレーサーに用いたPET研究が注目されて いる。本研究では、ラット脳梗塞モデルに対してMSC 投与を行い、[18F］DPA-714 PETイメージングを用い て神経免疫反応の評価が可能か検討する。

【方法】ラット一過性中大脳動脈閉塞 (90min) モデルを 作成した。同種のMSCを培養し、再灌流 1 時間後に 3 $\times 10^{6}$ 個の細胞を経静脈的に投与した。投与後 3 日と 10 日に $[18 \mathrm{~F}]$ DPA-714を投与し小動物用PETを用いてイ メージングを行った。投与後 2 週間まで継続的に神経 学的検討(Neurological severity score、体重測定)を行 い、その後、脳及び全身の免疫器官(脾臓、胸腺、リ ンパ節)の組織学的検討を行った。

【結果】虚血後、強い神経障害と体重減少を示したが、 MSC群では有意に抑制され脳梗塞体積も減少した。脳 虚血の影響により、脾臟と胸腺の重量は減少し脳梗塞 体積と負の相関関倸を示した。さらに脾臟と胸腺にお いてCD8 $a^{+} T$ 細胞の減少、脳虚血部ではCD $8 a^{+} \mathrm{T}$ 細胞の 浸潤とCD68+マイイクグリア/マクロファージの増加が 見られたが、MSC群では抑制されていた。［18F］DPA714 PETでは、虚血3日後には両群とも虚血領域で高い Standardized Uptake Values (SUV)が見られたが(mean SUV ; BMSC 群 : $2.30 \pm 0.14$ 、vehicle 群 : $2.37 \pm 0.12$ )、 虚血10日後では、MSC群にてSUVの上昇が有意に抑制 された(BMSC群 : $2.58 \pm 0.15$ 、vehicle群 : $3.03 \pm 0.06$ )。 【結語】 [18F］DPA-714 PETによりMSC投与後に虚血 後の神経免疫反応が抑制される所見を画像化でき、こ の手法の有用性が示された。 


\section{ヒト脳梗塞組織における多能性幹細胞の 同定}

${ }^{1}$ 兵庫医科大学 脳神経外科講座、 ${ }^{2}$ 兵庫医科大学 先端医学研究所 神経再生研究部門

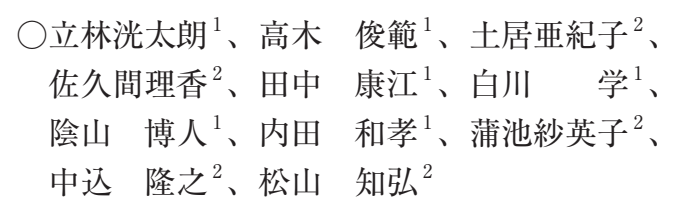

我々はこれまで、脳梗塞モデルマウスを用い、その 梗塞巣の血管腔近傍には虚血負荷により多分化能を 獲得した虚血誘発性多能性幹細胞iSCs：ischemiainduced multipotent stem cellsが存在することを報 告してきた。iSCsは、ペリサイトを起源とし、神経 系細胞への分化能のみならず、血管系細胞への分 化能を有することから、脳傷害後のneurovascular unitの再構成を標的とした臨床応用に寄与する可能 性がある。しかし、ヒトの脳梗塞組織にも同様の細 胞が存在するか否かについては明らかではなかっ た。本研究では倫理委員会の承認後、広範な脳梗塞 に罹患した患者で、外科的な外減圧術及び内減圧術 (partial lobectomy)が必要と考えられた患者家族か ら同意を得た上で、ヒト脳梗塞組織の摘出サンプル の一部を用いて検討を行った。ヒト脳梗塞組織の免 疫染色では、血管腔近傍にペリサイトマーカー及び 神経幹細胞マーカーを共発現する細胞の存在が明ら かとなった。これらの細胞を単離、培養し、PCR法 を行ったところ、星細胞系マーカー、内皮細胞系マー カーの発現は認めず、ペリサイトマーカー、神経 堤マーカーの発現を認めた。また、単離したiSCsを OGD (Oxygen glucose deprivation) 下にて培養す ると、ペリサイトマーカーの発現低下とSOX2 発現 増強を認め、MET (mesenchymal epithelial transition）を介して、ペリサイトが幹細胞能を獲得して いることが示唆された。さらにiSCsは継代を重ねて も幹細胞マーカーの発現を失わないこと、脂肪、骨、 軟骨及び成熟神経への多分化能を有することを確認 した。我々はヒトの脳梗塞後の脳内にiSCsが存在す ることを実証した。iSCsは神経細胞に分化すること ができ、脳梗塞後の神経修復に重要な役割を果たす 可能性があると考えられた。

\section{骨髄間葉系幹細胞によるアストロサイト の多分化能促進}

神戸大学大学院 理学研究科

\section{$\bigcirc$ 齋藤 喜仁、森田 光洋}

骨髄間葉系幹細胞 (Mesenchymal stem cells；MSC) が脳傷害の回復を促進するメカニズムには不明な点 が多く残されている。本研究では、脳傷害の回復過 程に関与することが報告されている神経幹細胞マー カーNestinを発現する活性化アストロサイトに着目 し、MSCがこの細胞の多分化能を促進する可能性 を培養系において検討した。具体的にはラット新 生児皮質由来のアストロサイトとラット骨髄由来の MSCを、神経幹細胞の培養に用いられる成長因子 EGFとbFGFを含む無血清条件下で共培養した。な お、MSCは識別のためGFPトランスジェニックラッ トより培養した。アストロサイトは成長因子処理に より増殖およびNestinとSOX2の発現が上昇し、さ らにMSCと共培養した場合に凝集がみられた。こ の凝集体にはアストロサイトとMSCが共存し、1週 間程度培養することにより Neurosphere様の形態を 示した。さらに、神経幹細胞の分化を誘導すること が知られている成長因子の除去を行うと、凝集体か らTuj1陽性の神経前駆細胞が産生されたため、こ の凝集体は神経幹細胞を含むことが示唆された。こ のTuj1陽性神経前駆細胞はGFP陰性であったこと から、MSCではなくアストロサイトに由来すると 考えられる。神経幹細胞の増殖や維持にはNotch シグナルやATPシグナルの関与が報告されており、 MSCとアストロサイトとの相互作用についてもこ れらの阻害剂を用いて検討した。その結果、Notch やATPシグナルの阻害剤で処理した場合、MSCに よる凝集がみられなかった。一方、これらの阻害剤 は単独で培養されたMSCの形態や増殖にも影響を 与えたため、上記のシグナルはアストロサイトに対 してのみならず、MSCの制御にも関わる可能性が 高い。以上の結果は、MSCがNotchやATP受容体の シグナルを介してネスチン陽性アストロサイトを神 経幹細胞にリプログラミングし、失われた神経細胞 などを補充することで組織再生を促進するという可 能性を示唆している。 


\section{脳梗塞後遺症の機能回復を目指した低酸 素低糖刺激保護的ミクログリア細胞療法}

\author{
${ }^{1}$ 新潟大学 脳研究所 神経内科、 ${ }^{2}$ 国立病院機構 新 \\ 潟病院 神経内科
○金澤 雅人 ${ }^{1}$ 三浦 南 ${ }^{1}$ 、鳥谷部真史 ${ }^{1} 、$

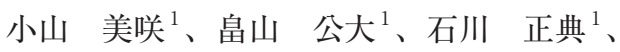 中島 孝 ${ }^{2}$ 、小野寺 理 $^{1}$ 、高橋 哲哉 ${ }^{1}$ 、 西澤 正豊 ${ }^{1}$ 、下畑 享良 $^{1}$

【目的】脳梗塞後遺症の機能を回復させる治療法の 確立が望まれている。組織障害性ミクログリアを 保護的ミクログリアに変化させる低酸素低糖刺激 (OGD)の条件を決定し、OGD-保護的ミクログリア を亜急性期に末梢動脈投与することで、脳虚血後の ラットの機能予後を改善させることが可能か検証す ることを目的とした。

【方法】最適な条件でOGDを行ったマウス初代ミク ログリアの培養上清を検体として、血管内皮増殖因 子(VEGF)、抗炎症性のトランスフォーミング増殖 因子 (TGF- $\beta$ ) や炎症性の腫瘍壊死因子 (TNF- $\alpha$ ) を含 むサイトカイン、MMP-9活性を、ELISA と FRET アッセイにより測定した。雄SDラットに一過性局 所脳虚血を誘導し、1週後、OGD-保護的ミクログリ アを、動脈投与し、虚血 4 週間、運動感覚スケール にて評価した。細胞投与による血管新生および軸索 伸展の効果を、両者のマーカー (CD31及び SMI31) に対する抗体を用いた免疫染色にて、虚血4週後に 評価した。

【結果】OGD刺激を行ったミクログリアの培養上清 のTGF- $\beta /$ TNF- $\alpha$ 比は、刺激前と比べて6 倍上昇し

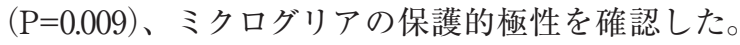
またVEGF、MMP-9は、OGD刺激前と比べて増加し た $(\mathrm{P}<0.01)$ 。このOGD-保護的ミクログリアを虚血 1 週後に投与することで、投与後 3 週後の脳実質でも、 VEGF、MMP-9、TGF- $\beta$ の発現の立進を免疫染色に て確認した。OGD-保護的ミクログリアを投与した群 の運動感覚機能は、対照群に比して、顕著な改善を 認めた $(\mathrm{P}=0.006)$ 。組織学的に、OGD-M2ミクログリ ア投与により、虚血中心の辺縁部における血管新生、 ペナンブラにおける軸索伸展が有意に増加した。

【結論】OGD-保護的ミクログリアの未梢動脈投与は、 亜急性期であっても脳梗塞後の機能を回復させた。 その機序としてVEGF、MMP-9、TGF- $\beta$ の発現によ る血管新生、軸索伸展が考えられた。本知見は従来 にない脳梗塞治療戦略につながるものと考えられる。

\section{創傷治癒過程を応用した2種類の幹細胞 を用いた脳梗塞治療法の開発}

${ }^{1}$ 先端医療振興財団 先端医療センター研究所 再生 医療研究部、 ${ }^{2}$ 兵庫医科大学 先端医学研究所 神経 再生研究部門

○笠原由紀子 ${ }^{1}$ 、松山 知弘 ${ }^{2}$ 、田口 明彦 ${ }^{1}$

【目的】創傷後の治癒再生には炎症期、増殖期および 成熟期が存在し、これら 3 要素の経時的な制御が重 要である。本研究では、脳梗塞後の理想的な脳神経 機能回復促進を目的とし、この3要素のなかで、ま ず(1) 炎症期 (急性期)に打ける過㮃な炎症抑制、(2) 增殖期 (亜急性期)に打ける微小血管網の活性化、の 2 要素の組み合わせによる相乗効果/相加効果の検 証を行った。

【方法】我々の開発した再現性の高いCB-17マウス中 大脳動脈永久閉塞モデルにより脳梗塞を作成し、炎 症期である脳梗塞作成 24 時間後に間葉系幹細胞ま たはPBS投与し、さらに増殖期である脳梗塞48時 間後には骨髄単核球またはPBS投与を行った。(1) PBS+PBS群、(2) 間葉系幹細胞+PBS群、(3) PBS+骨 髄単核球群、(4) 間葉系幹細胞+骨髄単核球群、の計 4 群を設定し、脳梗塞作成 3 日目の炎症反応と血管 反応性、及び脳梗塞作成 30 日目の脳萎縮改善度と 神経機能改善を評価した。

【結果】脳梗塞作成 3 日目において、炎症期に間葉系 幹細胞投与した群ではmicrogliaの活性が抑制され、 また、増殖期に骨髄単核球を投与した群では微小血 管の活性化が観察された。炎症期に間葉系幹細胞+ 増殖期に造血幹細胞を投与した群においては、脳梗 塞作成 3 日目において microgliaの活性の抑制と共に 微小血管の活性化が見られ、脳梗塞作成 30 日目の 脳萎縮改善度や神経機能改善も間葉系幹細胞+骨髄 単核球群が最も優れていた。

【結論】本研究の結果は、「適切な時期」に「適切な細 胞」を組み合わせて用いることで相加/相乗効果が生 まれ、より理想的な脳の機能再生が得られる可能性 があることを示唆している。 


\section{脳梗塞に対する自家骨髄間質細胞移植： RAINBOW研究}

\author{
${ }^{1}$ 北海道大学 脳神経外科、 2 富山大学 脳神経外科 \\ ○川堀 真人 ${ }^{1}$ 、七戸 秀夫 ${ }^{1}$ 、寺坂 俊介 $^{1}$ 、 \\ 黑田 敏 ${ }^{2}$ 、宝金 清博 $^{1}$
}

近年、脳梗塞に対する細胞治療に期待が集まるが、 自家骨髄間質細胞 (bone marrow stromal cells; BMSC) は、生命倫理や腫瘍形成の問題がないなど 臨床応用に有利であると考えられる。我々は現在、 自家BMSC移植による脳梗塞再生治療に関する医師 主導治験(RAINBOW研究) 開始しているが、本 発表では昨年発出された「脳梗塞の細胞治療製品の 開発に関するガイドライン」に準拠した治験院内体 制整備について報告する。ガイドラインは大きく品 質、非臨床、臨床の3つのパートによって構成される。 品質においては原材料、製造方法、最終製品におい て留意すべき、感染性物質の混入チェック、製品の 表面抗原等の確認試験、細胞生存率、保存流通時の 安定性など複数の項目において確認するよう求めて いる。非臨床試験では投与時期、経路、細胞数など、 実際の治験に類似した環境での動物試験デザイン策 定や、投与細胞の生体内での分布イメージング、そ して一般毒性や造腫瘍性モデルにおける安全性の確 認が必要とされている。臨床では対照患者群の決定、 用法用量、投与方法と静脈投与以外における投与デ バイスの開発、安全性評価、有効性評価などについ て指針が示されている。本治験では、これらの項目 を可能な限り遵守して治験デザインを構築しており、 かつ以下の3 点、1) 他家ヒト血小板溶解物 (platelet lysate：PL)を用いた細胞培養法、2)脳定位的手術 による脳梗塞周辺部への直接移植、3) 超常磁性酸化 鉄 $(\mathrm{SPIO})$ 製剤の細胞ラベリングによる移植細胞卜 ラッキング、など新規性あるプロトコールを採用し ている。脳梗塞の細胞治療に対するBench to bedに 至る課程に必要なプロセスを説明すると共に、治験 のpreliminary dataも併せて報告する。

\section{Trousseau症候群における高分子ムチン と凝固系マーカー・脳梗塞病型との関連}

東海大学医学部付属八王子病院

\author{
○陳佑佳、阿部 哲郎、中山 平、 \\ 徳岡健太郎、北川 泰久、野川茂
}

【目的】Trousseau症候群は腺癌によるものが多く、 しばしば脳梗塞を合併するが、その原因は不明で ある。腺癌腫瘍マーカーであるCA19-9やCA125は、 血中で高分子ムチンとして存在し、プロトロンビン の活性化やp-セレクチンを介して血栓形成に関与す る可能性が指摘されている。本研究では、高分子ム チンの脳梗塞発症における役割を明らかにすること を目的とした。

【方法】凝固能が光進し、脳梗塞を合併した担癌患者 22 例 $(77.4 \pm 7.4$ 歳、男性 13 例、女性 9 例 $)$ を対象と し以下を検討した：1) 悪性腫瘍の種類、2)凝固線溶 系マーカー：FDP、D-dimer、TAT、a2PIC、3)腺 癌腫瘍マーカー：CEA、CA19-9、CA125、4)心不 全マーカー：BNP、5)頭部MRI所見。

【成績】1）原発癌の内訳は、胃癌 7例、直腸癌 4例、 肺腺癌 3 例など、全例が腺癌であった。2) 凝固系マー カーでは、FDP $29.7 \pm 37.8(\mu \mathrm{g} / \mathrm{mL}) 、$ D-dimer 17.8 $\pm 17.3(\mu \mathrm{g} / \mathrm{mL}) 、$ TAT $13.5 \pm 18.3(\mathrm{ng} / \mathrm{mL}) 、$ PIC 1.6 $\pm 1.3(\mu \mathrm{g} / \mathrm{mL})$ と高值を示した。3)腺癌腫瘍マーカー は、CEA $343.2 \pm 1509.3(\mathrm{U} / \mathrm{mL}) 、 \mathrm{CA} 19-94403.6 \pm$ $11003.0(\mathrm{U} / \mathrm{mL}) 、 \mathrm{CA} 125370.7 \pm 997.4(\mathrm{U} / \mathrm{mL})$ と 高值を示した。CEAはFDP、D-dimer、TAT（ピア ソン相関係数 $r: 0.5759 、 0.4483 、 0.5184)$ と、CA19-9 はFDP、D-dimer、TAT ( $\mathrm{r}: 0.4096 、 0.4342 、 0.4534)$ と、 CA125はD-dimer ( $r: 0.5248)$ と有意な相関を示した。 4) BNPは209.7 $\pm 216.6(\mathrm{pg} / \mathrm{mL})$ と高值で、CA125 と弱い相関 (r:0.3007)を示した。5)頭部MRIでは、 脳主幹動脈から末梢まで大小不同の梗塞巣を認めた。 このうち脳主幹動脈閉塞群と複数小梗塞群では、上 記マーカーと有意な相関は認めなかった。

【結論】Trousseau症候群における脳梗塞はCA19-9、 CA125が高值で、凝固線溶系マーカーと相関し、こ れらが直接血栓形成に関与している可能性があるが、 脳梗塞病型による違いはみられなかった。CA125は 心不全の程度と相関する可能性があるが、症例を蓄 積して検討する必要がある。 


\section{血清 $\alpha$ 2マクログロブリンと炎症性サイ トカインの関連：脳心血管リスク因子保 有例での検討}

\author{
${ }^{1}$ 広島大学大学院 脳神経内科学、 ${ }^{2}$ 放射線影響研究 \\ 所、 ${ }^{3} \mathrm{JCHO}$ 星ヶ丘医療センター
}

\section{$\bigcirc$ 祢津 智久 ${ }^{1}$ 、細見 直永 ${ }^{1}$ 、下村 怜 ${ }^{1}$ 、 青木 志郎 ${ }^{1}$ 、高橋 哲也 ${ }^{1}$ 、林 奉権 ${ }^{2}$ 、 松本 昌泰 ${ }^{3}$ 、丸山 博文 ${ }^{1}$}

【背景・目的】 $\alpha 2$ マクログロブリンは、プロテアー ゼ阻害タンパクの一つであり、凝固充進に関連する。 また、様々な炎症性サイトカインの調節に関わる ことも報告されている。我々は $\alpha 2$ マクログロブリ ンが脳細小血管障害のバイオマーカーとなること $(\mathrm{J}$ Neurol 2012)、血管内皮機能障害を反映することを 報告してきた(第59回脳循環代謝学会)。今回、 $\alpha 2$ マクログロブリンと炎症性サイトカインの関連を横 断的に調査した。

【方法】脳心血管リスク因子を有する患者 102 例(男 性69例、70 0 9歳)を対象とした。頸動脈超音波 検査と血管内皮機能検査 (flow-mediated dilation : FMD)を行い、同日採取した血液サンプルから血清 $\alpha 2$ マクログロブリン值、高感度CRPを測定し、BioPlex Proヒトサイトカイン27-plexを用いて各種炎症 性サイトカインを測定した。炎症性サイトカインの

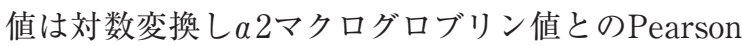
相関係数を算出した。

【結果】高感度CRPを含めた全炎症性サイトカイン 28 種類の中で、Interferon-inducible protein of $10 \mathrm{kD}$ (IP-10)のみが $\alpha 2$ マクログロブリンと正に相関した （R2=0.099、 $\mathrm{p}=0.001 ） 。 \mathrm{IP}-10$ は年齢、性、BMI、契 煙歴、脳卒中既往、冠動脈疾患既往、高血圧、糖尿 病、脂質異常症、心房細動、慢性腎障害で補正後も、 $\alpha 2$ マクログロブリンと関連した(重回州分析、 $\beta$ 0.256、 $\mathrm{p}=0.007) 。 I P-10$ は血管内皮機能 (FMD值)に は関連しなかったが、頸動脈超音波でのプラークス コア高值と独立して関連した（重回帰分析、 $\beta 0.247$ 、 $\mathrm{p}=0.004$ )。

【結論】脳心血管リスク因子を有する患者において、 血清 $\alpha 2$ マクログロブリンはIP-10 と正に相関した。 IP-10は頸動脈硬化の重症度を反映する可能性が示 唆された。

\section{脳小血管病と緊急血栓回収療法の臨床転 帰との関係}

${ }^{1}$ 札幌医科大学 医学部附属フロンティア医学研究 所 神経再生医療学部門、 ${ }^{2}$ 札幌白石記念病院 脳血 管内治療センター、 ${ }^{3}$ 札幌白石記念病院 脳神経外 科

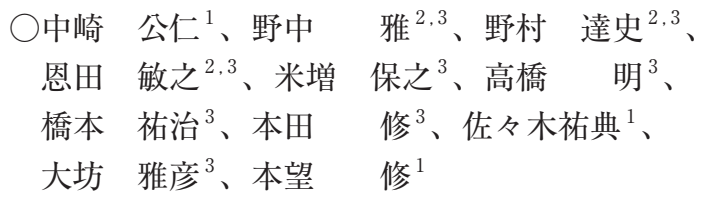

【目的】脳小血管病 (CSVD)が緊急血栓回収療法 3 ヶ 月後の臨床転帰に影響を与えるのかを検証した。 【方法】1)2013年1月から2017年3月の間に、2） MRI を施行し、3) 急性期内䅡動脈、または中大脳動脈 (M1またはM2) 閉塞の診断で、4)8時間以内に血 栓回収療法を施行した症例、を後ろ向きに調査し た。CSVDは、治療前MRIにて脳白質病変 (Swieten scale 2-4)、陳旧性ラクナ病変、陳旧性微小出血病 変、のいずれかの病変があるものと定義した。対 象患者をCSVDがある (CSVD) 群、とCSVDがない (non-CSVD) 群の二群に分け、患者背景と 3 ヶ月後 mRSを比較検討した。さらに、CSVDの有無が長期 予後に影響を与えるのかを多变量解析を用いて解析 した。

【結果】63例が調査対象となった。年齢平均値は73.3 才、 $27(43 \%)$ 例が女性、入院時NIHSSは16、治療 前DWI-ASPECTSは8点、再開通率は79\%だった。 63症例のうち、CSVD群は37例、non-CSVD群は26 例であり、患者背景には有意差がなかったが、3ヶ 月後のmRSが0-2の割合は、CSVD群で有意に低かっ た[CSVD群 : 43\%、non-CSVD群 : 96\%、P $<0.01$ 。 さらに、3ケ月後のmRSが0-2に対するロジスティッ ク回帰分析においても、CSVDが独立した予測因 子の一つだった $(\mathrm{OR}=0.02 、 95 \%$ confidential interval ; $0.01-0.16 、 \mathrm{P}<0.01)$ 。

【結論】前方循環に対する緊急血栓回収療法において、 治療前にCSVDがないと、3ヶ月後の臨床予後は良 好であり、CSVDの有無が独立した子測因子の一つ であった。 


\section{潜因性脳梗塞患者における 1 週間心電図 モニタリング有用性の検討}

東京女子医科大学 神経内科

○遠井 素乃、白井 優香、石塚健太郎、
久保田 愛、関 美沙、樋口 瑛子、
北川 一夫

【背景】Embolic stroke of undetermined source、 ESUS (潜因性脳梗塞) は、塞栓源不明の脳梗塞とい う新しい概念である。発作性心房細動が塞栓源とし て最多と想定されるが、頻度や再発予防は議論中で ある。

【目的】ESUS患者において、1週間連続ホルター心 電計を用い発作性心房細動の有無を検討する。

【方法】対象は、東京女子医科大学神経内科にて ESUSと診断された 30 症例、体外装着式心電図記録 器にて、1週間連続心電図をモニタリングし、専用 ソフトで解析した。入浴時以外装着の上連続的に記 録した。

【結果】ノイズの多い例を除き、対象患者は、男性 18 人、女性 8 人、平均年齢; $70.7 \pm 13.3$ 歳 (男性 67.0 歳 ; 女性 80.0 歳)。発症から検査までの期間は、15.9 \pm 31.0 ケ月。平均測定時間 $167.2 \pm 12.5$ 時間。対象 患者のうち 1 例に 16 時間以上持続する発作性心房細 動が検出された。危険因子は、心不全 $0(0 \%)$ 、高 血圧症 $15(57.7 \%) 、$ 糖尿病 $9(34.6 \%)$ 、脂質異常 症 $12(46.2 \%) 、$ 脳卒中の既往 $8(34.6 \%)$ 、契煙 14 $(53.8 \%)$ だった。

【結論】今回のESUSの定義を満たした症例を用いた 検討では、1週間心電図モニタリングを行ったとこ ろ、心房細動が1例検出され、塞栓源としての発作 性心房細動が確認された。今後も、検出されなかっ た症例を再検して心房細動の有無を確認するほか、 更なる症例の蓄積が必要と考えた。

【結語】長時間心電図モニタリングにて発作性心房細 動を検出することができた。ESUSを対象とした既 知の報告より、実際は発作性心房細動の出現頻度は 低い可能性が示唆された。

\section{高血圧患者におけるアジルサルタンの頭 蓋内病変の進行抑制効果の検討}

${ }^{1}$ 岩手医科大学付属病院 神経内科老年科、 ${ }^{2}$ 岩手医 科大学医歯薬総合研究所、 ${ }^{3}$ 盛岡駅前おおば脳神経 内科クリニック

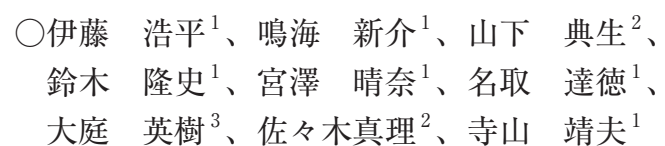

【背景】高血圧と頭部MRIにおける微小出血、大脳白 質病変、ラクナ梗塞の間には密接な関係がある。ま た、血圧日内変動の異常が血圧レベルとは独立した 脳卒中の危険因子であることが報告されている。新 規の angiotensin II receptor blocker (ARB)である アジルサルタンは血圧日内変動をdipper型へと正常 化させる作用を持つとされる。そこで、我々はアジ ルサルタンが従来の ARBと比較して頭蓋内病変の 進行抑制に有効であるかを前向きに検討した。

【方法】当科外来でARB内服中の患者 104 名を、従来 のARB継続群、アジルサルタン変更群に分けて登 録時、18ヶ月後に頭部MRI、24時間血圧測定を施 行し、ラクナ梗塞、微小出血、Fazekas score、白 質病変の体積の経時的変化ならびに平均血圧 (終日、 日中、夜間)、血圧日内変動パターンを評価した。

【結果】104名のうち33名が脱落し、最終的に71名が 解析対象となった。継続群と変更群の臨床的背景に 差は認めなかった。両群間で、ラクナ梗塞、微小出 血、Fazekas score、白質病変の体積の増加量に有 意差は認めなかった $(\mathrm{p}=0.45 、 0.87 、 0.43 、 0.36) 。 24$ 時間血圧測定では、変更群で平均収縮期 - 拡張期血 圧、夜間拡張期血圧が有意に低下していた $(\mathrm{p}=0.04$ 、 0.03、0.02)。変更群で18ヶ月後にdipper型を示す 症例が増加していたが、有意差は認めなかった $(\mathrm{p}=0.08)$ 。1 8 ケ後にdipper型を示した症例と非 dipper型を示した症例間で、ラクナ梗塞、微小出血、 Fazekas score、白質病変の体積の増加量に有意差 は認めなかった $(\mathrm{p}=0.35 、 0.26 、 0.70 、 0.84) 。$

【結語】アジルサルタンは従来の ARBと比較し強力 な降圧作用を有することが示唆されたが、頭蓋内病 変の進行抑制効果は明らかではなかった。 


\section{非弁膜症性心房細動を有する急性期脳梗 塞患者における病前抗凝固療法と梗塞体 積・閉塞血管の関連の検討}

日本医科大学 神経・脳血管内科

○坂本 悠記、仁藤智香子、木村 和美

【背景】心房細動を有する脳梗塞患者において、病前 ワルファリン内服は梗塞体積が小さく、主幹動脈閉 塞が少ないことと関連することが知られている。し かし、病前の直接経口抗凝固薬 (Direct oral anticoagulant：DOAC) 内服と梗塞体積や閉塞血管との関 連は不明である。

【対象】2011年 3 月 14 日〜 2016年 3 月に当科入院した 非弁膜症性心房細動を有する、前方循環に生じた虚 血性脳血管障害患者連続例。

【方法】入院時の Diffusion-Weighted Imgaging (DWI)を用いてAlberta Stroke Program Early CT score (ASPECTS)を算出し、MR angiography に よって閉塞血管の有無、部位を判定した。これらを 病前抗凝固療法の有無・内容毎にまとめ、比較した。 【結果】 345 例 (女性 $46 \%$ 、中央値 79 歳)に関して検討 した。病前に抗凝固療法を施行されていたのは97例 (28\%)であり、このうち28名 (29\%)にDOACが処方 されていた。入院時DWI-ASPECTSは、病前抗凝固 療法を施行されていなかった群で中央值7 (四分位 值 5-9)、DOAC内服群で9 (7-10) と有意な差を認め

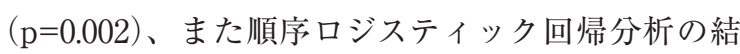
果、病前DOAC内服は、独立してょり近位の血管閉 塞を起こさないことと関連した (OR 0.39、 $\mathrm{p}=0.031)$ 。 【結論】DOAC内服は、非弁膜症性心房細動を有す る脳梗塞患者の近位血管閉塞が少なく、梗塞体積が 小さいことと関連する。

\section{パーキンソン病における cerebral mi- crobleeds (CMBs) と認知症の関係につ いて}

${ }^{1}$ 順天堂大学 医学部 脳神経内科、 ${ }^{2}$ 順天堂大学 医 学部 脳神経外科

$\bigcirc$ 田中 亮太 ${ }^{1} 、$ 山城 一雄 ${ }^{1}$ 、大山 彦光 ${ }^{1}$ 、 梅村 淳 ${ }^{2} 、 下 \quad$ 泰司 ${ }^{1}$ 、服部 信孝 ${ }^{1}$

【背景】Cerebral microbleeds (CMBs) は脳卒中や アルッハイマー病に多くみられる。我々の報告も含 め、パーキンソン病に打いてもCMBsが高頻度に認 められることが明らかになってきた。一方でパーキ ンソン病に扮ける $\mathrm{CMBs}$ の存在が認知症に与える影 響については分かっていない。そこでパーキンソン 病に扔けるCMBsの存在と認知症の関倸について後 方視的検討を行った。

【Methods】2014年 1月〜2016年 7月に順天堂医院脳 神経内科に入院したパーキンソン病 124 例について 後方視的に検討した。Parkinson's disease with dementia (PDD)の診断はいわゆる”1-year rule”に基 づき行い、MDS Task Force の診断基準を用いて 診断した。入院時の臨床データ、MRI、24h ABPM おける夜間血圧下降度とPDDに対する影響を検討 した。

【Results】124名のパーキンソン病の内 21 名(16.9\%) がPDDであった。CMBsは18名(14.5\%)に認めら れた。年齢、性別(男性)、Yahr stage、脳卒中の 既往、起立性低血圧 $(\mathrm{OH}) 、 \mathrm{MRI}$ の periventricular hyperintensity $(\mathrm{PVH})$, deep white matter hyperintensity (DWMH)、CMBs、そして24h ABPM によるriser patternがPDD群で有意に関連してい た。ロジスティック回帰分析を行いPDDの危険因 子について多変量解析を行ったところ、性別、起立 性低血圧 (OR 68.2、95\%CI 4.96-3547.1)、PVH (OR 8.06、95\%CI 1.94-55.1)、皮質領域に限局したCMBs (strictly lobar CMBs) (OR 57.2、95\%CI 1.5-12608.2) がPDDの独立したリスクであった。

【Conclusion】パーキンソン病における認知症合併 はCMBsと関連していた。特にstrictly lobar type CMBsはPDDの独立した危険因子であった。 


\section{脳挫傷症例におけるleakage signの検討}

久留米大学 医学部 脳神経外科

○折戸 公彦、山本 真文、吉富 宗健、 竹内 靖治、廣畑 優、森岡 基浩

【背景・目的】頭部外傷traumatic brain injury (TBI) において血腫増大は予後を左右する重大な要素であ る。造影CTにより血腫の増大および予後を予測し ようとする試みはあるが、十分とは言えない状況で ある。我々は、造影剤注入後 5 分後に単純CT撮影 を追加する事によって、より鋭敏に造影剤の漏出を とらえることが可能であることをleakage signとし て脳内出血症例において報告してきた。今回は報告 の少ない脳挫傷病変のみを対象に検討をおこなった ので報告する。

【方法・対象】 2012 年 4 月〜 2015年 8 月までの当院 へ救急搬入となった 247 のTBI患者の中で、硬膜下 血腫等を伴わない33例 (age : $64.1 \pm 20.6$ years ; 24 men、 7 women) の脳挫傷患者を対象として検討を 行った。造影CTの元画像とその5分後の delayed phaseに撮影した画像で $10 \mathrm{~mm}$ の ROIを設定し、10\% 以上の数值の上昇を認めた場合にleakage signを陽 性とし、血腫増大、予後の検討を行った。

【結果】 leakage signは血腫の増大を $100 \%$ の特異度 92.8\%の感度をもって予測する事が可能であった。 また退院時のGlasgow Outcome scale (GOS)におい て、leakage signの有無による有意な差は認められ なかったが、24時間後のGlasgow Coma scale (GCS) ではleakage sign陽性患者は有意なGCS低下を認め た。

【結語】 leakage sign は脳挫傷患者において血腫の 増大を予測し、治療方針決定に必要な情報を提供し てくれる道具となり得る可能性がある。

\section{人工知能によるpreclinical ADのMR画像 による診断-BAADとVSRADの比較-}

${ }^{1}$ 滋賀医科大学 神経難病研究センター、 ${ }^{2}$ 立命館大 学 情報理工学部、 ${ }^{3}$ 山口大学 理学部

○椎野 顯彦 ${ }^{1}$ 、韓 先花 ${ }^{3}$ 、Vigers Piers ${ }^{1}$ 、 白樫 義知 ${ }^{1}$ 、岩本祐太郎 ${ }^{2}$ 、陳 陳 ${ }^{2}$

【目的】MR画像によるアルッハイマー病 $(\mathrm{AD})$ の 発症前診断のための技術を開発する目的で、Voxel-based morphometry (VBM) と人工知能を組み合 わせたソフトを開発した。

【方法】人工知能の学習には北米のADNI database を用いた。健忘型軽度認知障害 $(\mathrm{aMCI})$ のうち $\mathrm{AD}$ を発症した進行型MCI (pMCI)68例、4年間の経過 観察でADに進行しなかった非進行型MCI (sMCI) 110 例を対象とした。 pMCIは発症から 3 年前のMRI、 SMCIはADNI登録時のMRIを用いた。それぞれ症例 のstructural MR画像を我々の開発したVBM解析ソ フトであるBAADで、AAL、Brodmann、LPBA40 のそれぞれの関心領域の萎縮の程度 $(z$ 值) の結果 を機械学習(RBFカーネル)に与え、leave-one outcross-validation法を合わせて適切なパラメーター を決定した。プログラムではpreclinical ADの可能 性をpMCI score (PMS) として計算するようにした。 同じデータをVSRAD (Advance2)で解析して比較 した。

【結果】検査時の年齢、MMSE、ADAS-Cog11のpMCI /sMCIは、それぞれ75.7/72.8、26.9/28.1、9.85/7.81、 APOE 4の保有率は4/4=10.6/5.5 (\%)、- $/ 4=55.3 / 37.3$ (\%)であった。PMSによる予測の正答率 $=85.4 \%$ 、 感度 $=78.7 \%$ 、特異度 $=88.2 \%$ 、検査後 Odds $=27.6$ 、 $\mathrm{AUC}=0.89$ であった。PMSの結果に年齢、年齢+ $\mathrm{APOE} 、$ 年齢 $+\mathrm{APOE}+\mathrm{ADAS} 、$ 年齢 $+\mathrm{MMSE}+\mathrm{ADAS}$ の情報を加えてもAUCはいずれも 0.89 と改善は なかった。VSRADの結果は正答率 $=65.7 \%$ 、感 度 $=51.5 \%$ 、特異度 $=74.5 \%$ 、検査後 Odds $=1.25$ 、 $\mathrm{AUC}=0.71$ であった。

【結論】 PMSが発症 3 年前のMRIでpreclinical ADを 高い精度で予測可能であることを示した。この結果 はVSRADよりも良好で、ADNIのaMCIでPiBを実 施した65例における $\mathrm{AD}$ 発症リスク $($ Odds $=9.29)$ よ りも高い精度であった。 


\section{0列 Multi-detector CT を使用した海 綿静脈洞に接続する頭蓋内静脈の血液量 の解析}

${ }^{1}$ 慶應義塾大学 医学部 脳神経外科、 ${ }^{2}$ 慶應義塾大 学 医学部 放射線診断科、 ${ }^{3}$ 慶應義塾大学 医学部

○水谷 克洋 ${ }^{1}$ 、戸田 正博 ${ }^{1}$ 、矢島 夢実 $^{3}$ 、 秋山 武紀 ${ }^{1}$ 、藤原 広和 ${ }^{2}$ 、陣崎 雅弘 $^{2}$ 、 吉田 一成 ${ }^{1}$

【背景と目的】現在までに脳微小静脈の血流量を定量 的に解析した報告はない。我々は320列Mutidetector CTを用いて海綿静脈洞の各分枝の血流量および 血流速度の相対的評価を試みた。

【方法】海綿静脈洞に関しては正常静脈解剖を有する と考えられる脳腫瘍患者の術前に撮影した造影 CT 画像を用いた。3D Workstation上で海綿静脈洞に接 続する各静脈にRegion of Interest（ROI）を設定し、 各時間点でのCT值を測定した。Recirculationの影 響を排除するために、得られたROIでの平均CT值 に対して最小二乗法を用いて非線形回帰分析を行い、 $\gamma$ 分布の確率密度関数 $\mathrm{f}(\mathrm{x})=\left(\mathrm{x}^{\wedge}(\alpha-1) \mathrm{e}^{\wedge}((-\mathrm{x}) /\right.$ $\beta)) /\left(\Gamma(\alpha) \beta^{\wedge} \alpha\right)$ 上にFittingを行った。これによっ て得られたTime Density Curve (TDC)の回帰式を 積分することで、Area Under Curve (AUC)の面積 を算出した。CT值は造影剂の濃度に比例するため、 この值は単位面積当たりの相対的血液量に相当する。 さらに血管の断面積をかけることで、それぞれの分 枝の相対的な血流量の関係を推測可能になった。ま た各分枝のAUCの平均值を比較することで、相対 的血流速度を推測することもできた。

【結果】海綿静脈洞に接続する各静脈の相対的な血流 量と血流速度を求めることができた。各分枝の静脈 の相対的血流量の分布は症例ごとに大きく異なった。 上錐体静脈洞は血流量の測定からは全例で海綿静脈 洞に流入していると推測された。

【結論】本法は頭蓋内静脈還流の解析方法として有用 であり、他の頭蓋内の静脈にも応用可能であり、静 脈の血流量からみた脳循環の理解の向上に役立つと 考えられる。

\section{MRI髄鞘イメージング「ミエリンマップ」 を用いた無症候性大脳白質病変における 䯣鞘障害の検討}

${ }^{1}$ 慶應義塾大学 医学部 神経内科、 ${ }^{2}$ 慶應義塾大学 医学部 放射線科、 ${ }^{3}$ 慶應義塾大学 医学部 整形外 科、 ${ }^{4}$ 慶應義塾大学 医学部 生理学教室

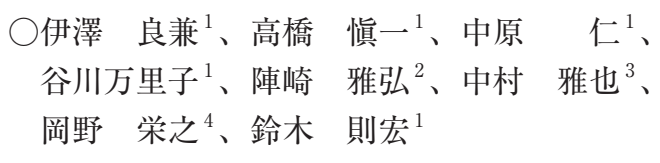

脳卒中や認知症のリスク因子とされる大脳白質病変 に対して、血圧や脂質の管理などが推奨されるもの の、根治療法はいまだ確立されておらず、その病態 の解明は契緊の課題である。MRIにおいてT2強調 画像、FLAIR画像で均質に観察される白質病変は、 病理学的にみた場合、有髄神経線維の密度低下やグ リオーシスなど不均一で多様な神経組織変化を示し ていると考えられる。そのため、白質病変に対する 治療を検討、確立する上で、オリゴデンドロサイト や髄鞘の障害の状態を特異的に、かつ簡便に繰り返 し評価できる頭部MRI撮像手法が必要不可欠と考え られる。我々は3T-MRIを用いて10分間で髄鞘を特 異的に描出可能な髄鞘イメージング「ミエリンマッ プ」を開発し、髄鞘障害の評価が実用レベルで初め て可能となった。ミエリンマップは $\mathrm{Q}$ space imagingの精度と、 diffusion kurtosis imagingの撮像時間 短縮の長所を併せた撮像方法といえる。今回、我々 は医学部倫理委員会の承認のもと、無症候性白質病 変の評価におけるミエリンマップの有用性を評価す るため、実臨床の患者を対象として、T2強調画像・ FLAIR画像・ミエリンマップによる無症候性白質病 変の撮影、比較検討を行った。結果、 $\mathrm{T} 2$ 強調画像 およびFLAIR画像で高信号に描出される白質病変 では、ミエリンマップで髄鞘障害の存在が示唆され た。また、T2強調画像、FLAIR画像で高信号に描 出され、一方ミエリンマップで異常が観察されない、 再髄鞘化を示唆する病変は、これまでのところ無症 候性白質病変の患者では確認されていない。このほ か、ミエリンマップは、T2強調画像およびFLAIR 画像よりも、髄鞘減少を鋭敏に検出する可能性が示 された。このようにミエリンマップは、髄鞘障害の 進行の評価や、白質病変に対する治療の有効性を検 討するうえで、有用な撮影手法となる可能性がある。 なお、本研究の一部は「脳ドックのガイドライン検 証研究助成金」により行われた。 


\section{虚血が血管周囲腔拡大に及ぼす影響}

札幌医科大学 医学部

○三上 毅、三國 信啓

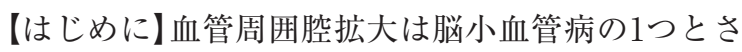
れ、アテローマ硬化症と異なった小血管の変化とさ れ、脳梗塞の再発や認知機能の悪化、運動障害と関 連しているといわれている。今回われわれは、動脈 硬化性変化による主幹動脈病変が血管周囲脭拡大に 及ぼす影響について、脳循環動態と合わせて検討し た。

【方法】2009年 4 月から 2017 年 6 月の間に、当院で頭 部MRIとIMP SPECTを撮像した内䅡動脈もしくは 中大脳動脈狭窄閉塞性病変 26 例を対象とした。男 性 20 例、女性 6 例、平均年齢65.9歳である。3T MRI、T2強調axial像で半卵円中心レベルにおける 拡大血管周囲腔数を測定し、病側と健側を比較し た。さらに、安静時及びアセタゾラミド負荷 IMP SPECTにより推定した脳循環動態から予備能低下 群(IH群) と非低下群(non-IH群)の 2 群に分けて、拡 大血管周囲胿数を比較した。尚、脳循環予備能低下 は、安静時で健側比 $0 \%$ 以下かつアセタゾラミド反 応性が $10 \%$ 以下と定義した。各数值は中央值 (4分 位範囲)を示している。

【結果】全体では、拡大血管周囲胿数は病側 50.5 (40.8) 個、健側 42.5 (12.0) 個と病側で多い傾向があるも のの有意な差はなかった $(\mathrm{p}=0.076)$ 。しかしなが ら、IH群とnon-IH群に分けて検討すると、IH群 64.1 (46.0) 個、non-IH群43.6 (22.0) 個とIH群で有意に多 かった $(\mathrm{p}=0024) 。 一$ 方で、IH群の中でもラクナ梗 塞を除く中等度以上の脳梗塞を生じた場合は 41.0 (23.0) 個と低下し、そうでない群は75.6 (20.0) 個で あり有意な差を認めた $(\mathrm{p}=0.005) 。 こ の I H$ 群の中で 中等度以上の脳梗塞を生じた例は、non-IH群と比較 して差はなかった $(\mathrm{p}=0.661)$

【結論】拡大血管周囲胿数は、脳循環予備能が低下し た場合により多く認められ、脳梗塞が生じた場合に は減少する。つまり、血管周囲腔拡大は脳循環予備 能低下状態において、脳梗塞が生じるまでの緩衝作 用として機能している可能性が示唆された。

\section{TMRIを用いた進行性BAD症例予測の試 み}

${ }^{1}$ 愛媛大学 医学部 脳神経先端医学講座、 ${ }^{2}$ 和昌会 貞本病院脳神経外科

$\bigcirc$ 伊賀瀬圭二 ${ }^{1}$ 、松原 一郎 ${ }^{2}$ 、鄭 菜里 ${ }^{2}$ 、 大西 丘倫 ${ }^{2}$ 、貞本 和彦 $^{2}$

【目的】Branch Atheromatous Disease (BAD)は、 脳主幹動脈の動脈硬化病変に伴う穿通枝障害性脳梗 塞であるが、発症早期に症状が進行する症例が多い。 我々はこれまで、3TMRIの新しいシーケンスによ り、頭蓋内主幹動脈壁の情報解析を行ってきた。今 回、進行性脳卒中の予測に応用できるか否か検討し たので、報告する。

【方法】2015年 4 月から 2017 年 3 月までに脳梗塞に て入院した患者の内、3T MRIを施行されBAD と 診断された、連続23例を対象とした。3T MRI装 置は、Discovery 750w (GE healthcare)を用いた。 T1-CUBEは、GE社の3D-FSEのシーケンスで、動脈 硬化性プラークを高信号に描出できる撮像法であり、 これを用いて、BAD症例において進行性脳卒中が 見られた群(進行群) と見られなかった群(非進行群) の2群に分けて解析した。進行性脳卒中は、発症後 1 週間内に、明らかな運動麻疩の進行を認めたもの と定義した。解析指標として、1. TOF-MRAにおけ る狭窄度を0-2点の3段階に評価し、2. T1-CUBEに おけるプラークの厚さおよび、3.プラークの全長に ついても検討した。

【結果】進行群は8例で、非進行群は15例であった。 TOF-MRAの狭乍度は、2 群間に有意差は認めなかっ た。T1-CUBEでは、非進行群 2 例以外の全 21 例で、 プラークが高信号に描出された。プラークの厚さお よび全長は、進行群 : $1.0 \pm 0.4 \mathrm{~mm}$ 拈よび $4.3 \pm 0.7 \mathrm{~mm}$ に対し、非進行群 $: 1.2 \pm 0.3$ 及び $3.0 \pm 0.6 \mathrm{~mm}$ であり、 プラークの全長において 2 群間に有意差を認めた $(\mathrm{p}$ $<0.05)$ 。

【結論】進行性BAD症例において、T1-CUBE法にお けるプラークの全長が、非進行例に対して、有意に 長いことが示された。今後、進行性BAD症例の予 知に応用できる可能性がある。 


\section{急性期血栓回収療法にて再開通が得られ た虚血脳組織におけるADC ratioを用い た可逆性の検討}

聖マリアンナ医科大学東横病院 脳卒中センター 脳 卒中科

$\bigcirc$ 植田 敏浩、高田 達郎、高石 智、 徳山 承明、臼杵乃理子、深野崇之、 辰野健太郎、篠原 健介、濱田 佑樹

【目的】急性期脳梗塞に対する血栓回収療法の進歩に よって、発症早期に再開通が得られて、DWIの高 信号領域が改善する症例も経験されるようになって きた。そこで今回我々は、本治療によって十分な再 開通が得られた症例を対象に、ADC值と再開通ま での時間を検討し、再開通が得られた領域における 虚血組織の可逆性について解析した。

【方法】対象は血栓回収療法にてTICI2B以上の再開 通が得られた 24 例 (平均年齢76歳)、閉塞血管は ICA11例、MCA (M1)7例、MCA (M2)6例。来院時 NIHSS15 (中央值)、DWI-ASPECT7 点 (中央值)、 tPA 静注は19例に施行した。来院時MRI-DWI画像 より 4 断面を選び、それぞれ皮質・白質領域に複 数のROIを設けて、対側と比較して relative ADC (rADC) 值を算出した。1-2週間後にMRIを再検し て最終梗塞巣を確認し、組織の可逆性を、rADC值 と虚血時間の関係から評価した。

【成績】TICI3は 12 例 $(50 \%)$ 。発症〜再開通、画像 〜再開通、穿刺から再開通まで時間は、それぞれ 192 分 (中央值)、104分、55分であった。退院時 mRS0-2は 17 例 $(71 \%)$ 。梗塞領域と梗塞を免れた領 域の平均 $\mathrm{ADDC}$ 值は、0.633と0.905で有意な差を認め た。（ $\mathrm{p}<0.001 ） \mathrm{ROC}$ 解析では、梗塞となる $\mathrm{rADC}$ 值の䦨值は、180分以内では0.769、180-240分では 0.792、240分以上では0.798であった。

【結論】発症早期に脳梗塞において、rADC值は組織 の可逆性の評価に有用であった。rADC值の高度な 低下は、超早期に再開通が得られても梗塞に陥る。 一方 $\mathrm{ADC}$ 值 $>0.8$ の場合には組織の可逆性が保たれ ていることが示唆された。

\section{pCASL CBFマップ変動係数による脳循環 評価の可能性 : PETとの比較による検証}

${ }^{1}$ 秋田県立脳血管研究センター 放射線医学研究 部、2 シーメンスヘルスケア

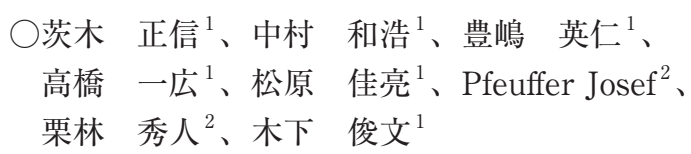

【目的】Pseudo-continuous ASL (pCASL) 臨床測定 では、収集時間の点で単時相収集 (single-PLD)が推 奨されるが、到達時間 (arterial transit time；ATT) 遅延領域では血管アーチファクトにより $\mathrm{CBF}$ 評価は 困難となる。一方、血管アーチファクト自体を脳循 環指標と考え、pCASL CBFマップの空間的変動係 数 (spatial coefficient of variation; sCoV)の利用が 提案されている(Mutsaerts JCBFM 2017)。本研究 では、 single-PLD pCASLによるsCoVの脳循環指標 としての有效性を検証することを目的とし、1) ダイ ナミック pulsed ASL (PASL)によるATT、2)脳循 環PETパラメータとの比較を行った。

【方法】片側性主幹動脈狭窄 - 閉塞症例 $(n=18)$ に対 しPET、ASL両検査を施行した。3T装置(MAGNETOM Verio、Siemens) を用いた3D GRASE収 集による single-PLD pCASL 測定 $(\mathrm{LD}=1,800 \mathrm{~ms}$; $\mathrm{PLD}=2,000 \mathrm{~ms})$ およびダイナミック PASL 測 定 を行った(開発中シーケンス)。pCASLデータ から CBFマップ、PASLデータから ATTマップ を計算した。大脳皮質領域両側にROIを設定し、 pCASL CBF sCOVは以下で計算した： $\mathrm{sCoV}(\%)$ $=100 * \mathrm{SD}^{\mathrm{ROI}} / \mathrm{Mean}^{\mathrm{ROI}}$ 。

【結果】各症例における $\mathrm{sCoV}$ の值は $20 \%$ ～60\%に分 布し、PASL ATTとの強い正相関 $(\mathrm{r}=0.63)$ がみら れた。PASL ATT、pCASL sCoV共にPET CBFと の有意な負相関 $(r=-0.44 /-0.51)$ およびMTTとの有意 な正相関 $(\mathrm{r}=0.50 / 0.58)$ がみられたが、その程度は pCASL sCoVの方が強かった。さらに、PETによる $\mathrm{CBF}$ 反応性 (CO2 吸入) との相関はpCASL sCoVに 対してのみ見られた $(\mathrm{r}=-0.39)$ 。

【考察・結語】 pCASL sCoVはATTと同様にPET パラメータと相関したが、程度はより強く、鋭敏 な脳循環指標となる可能性がある。PET MTTとの 関連が最も強かったが、到達遅延を反映するパラ メータとして妥当な結果といえる。通常臨床での single-PLD pCASL収集においても、ATT情報の取 得が可能である。 


\section{頭蓋内脳動脈狭窄/閉塞による急性期脳梗 塞患者の離床〜Arterial Spin Labeling を用いた比較〜}

${ }^{1}$ 昭和大学江東豊洲病院 脳神経内科、 ${ }^{2}$ 昭和大学江 東豊洲病院 脳神経外科、 ${ }^{3}$ 昭和大学江東豊洲病院 リハビリテーション科、 ${ }^{4}$ 昭和大学医学部 内科学 講座 神経内科学部門

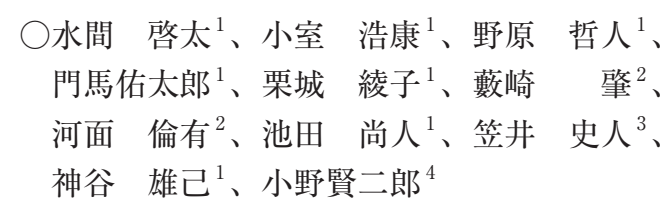

【背景】頭蓋内脳動脈狭窄/閉塞による急性期脳梗塞 患者では、血行力学的な症状増悪により離床の遅れ につながることがある。灌流評価を非侵襲的に行い、 離床を早期に進めリハビリテーションを行った報告 はない。

【目的】頭蓋内脳動脈狭窄/閉塞による急性期脳梗塞 患者に扔いて、非侵襲的かつ簡便に灌流画像が撮像 できるMRI-Arterial Spin Labeling (ASL) 法を用い て、描出の相違が神経症状増悪を予測し早期離床の 判断に有用かを検討した。

【方法】2016 年 5 月から 2017 年 5 月までの期間で、当 院での頭蓋内脳動脈狭窄/閉塞による急性期脳梗塞 患者のうち、再開通療法施行例を除外した中大脳動 脈狭窄症/閉塞 13例を対象とした。MRI-ASLを post labeling delay (PLD) $1.5 \mathrm{~s} / 2.5 \mathrm{~s}$ の 2 相で撮像し、カラー マップの左右差の有/無 $(\mathrm{p} / \mathrm{n})$ で1.5p群/n群、2.5p群 $/ n$ 群に分け、離床日数、神経症状増悪の有無、予後 を評価した。

【結果】年齢、病着時NIHSSの中央值はそれぞれ70歳 (41-79歳)、 5 (1-20)であった。1.5p群は10/13例 (77\%) で2.5p群は6/13例(46\%)であった。2.5p群の3例で症 状の増悪を認め、全例で経皮的脳血管形成術を施行 した。1.5p群/n群では症状の増悪に有意差を認めな かった。入院〜車いすの日数の中央值は $1.5 \mathrm{p}$ 群 $/ \mathrm{n}$ 群が 7日(1-24日）/4日(1-4日)、2.5p群/n群が10日(6-24日) $/ 1$ 日 (1-12日)であった。入院〜立位の日数の中央值 は1.5p群/n群が8日(3-27日) /5日(2-5日)、2.5p群/n群 が10.5日(7-27日) /4日(2-13日)であった。PLD2.5sに おいて離床までの日数に有意差を認めた。予後不良 (mRS3-6)は2.5p群にのみ3/13例(23\%)で認めた。

【結論】頭蓋内脳動脈狭窄/閉塞では、MRI-ASLにお けるPLD2.5sで血流の左右差がない場合は、症状増 悪の低リスクと判断でき早期離床が可能となる。

\section{Diffusion tensor imagingを用いた急性 期脳卒中例への下肢装着型HALによるリ ハビリテーション効果の検討}

${ }^{1}$ 国立循環器病研究センター 脳内科、 ${ }^{2}$ 国立循環器 病研究センター研究所 画像診断医学部、 ${ }^{3}$ 国立循 環器病研究センター 循環器病統合情報センター統 計解析室、 ${ }^{4}$ 国立循環器病研究センター 脳血管リ ハビリテーション科

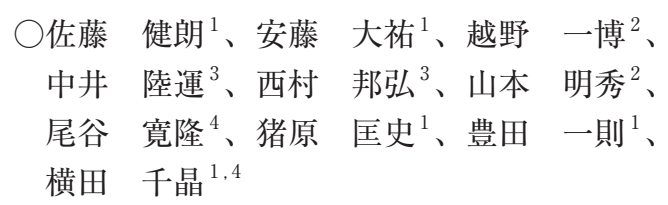

【目的】急性期脳卒中例に対して、従来のリハビリ テーション(従来療法)に下肢装着型補助ロボット (HAL)による歩行運動療法を加えた療法の効果を、 歩行動作改善とdiffusion tensor imaging (DTI)によ る神経線維密度の変化を指標に検討した。

【方法】対象は、2016年10月から2017年3月までに、 発症 48 時間以内に入院した脳卒中例でFunctional Ambulation Categories 1-2016例 (男性13例、平均 68 歳)である。前半 3 ケ月は従来療法を行う対照群 (8 例)、後半 3 个月は従来療法に加えて HAL (9回)を 行うHAL群 (8例) を登録した。登録時、3 週間後、3 か月後でFugl-Meyer Assessment (FMA)、Functional Independence Measure (FIM)、6m歩行の歩 数、歩幅、cadence (歩数/分)を比べた。DTIでの fractional anisotrophy (FA) 值は、各群間での登録 時と3か月後、および3 月後の両群間で比較した。

【結果】Ccadenceは、対照群に比べてHAL群で3週 間後 (15対 56 歩数/分、 $\mathrm{p}=0.014$ )、 3 か月後 ( 34 対 75 歩数/分、 $\mathrm{p}=0.026$ )いずれも改善した。登録時と 3 ヶ 月後では、FMA、FIM、6m歩行の歩数、歩幅には いずれも両群で差がなかった。対照群の3か月後FA 值は登録時に比べて、健側錐体路で上昇した $(\mathrm{p}<$ 0.001)。一方、HAL群のFA值は、登録時と3か月後 で差はなかった。3か月後FA值は、HAL群では対 照群に比べて上昇している部位はなかったが、対照 群ではHAL群に比べて健側錐体路、患側赤核、前 部带状回で上昇していた $(\mathrm{p}<0.001)$ 。

【結論】急性期脳卒中例にHALを用いたリハビリテー ションは従来療法に比べて cadenceが改善した。対照 群でのFAの変化は、運動機能障害に伴う神経の可塑的 変化の可能性がある。一方HAL群では FAの変化はな く、HALは神経回復過程に影響を与えた可能性がある。 


\section{総頸動脈拡張末期血流速度左右比(CCA ED ratio)による一過性脳虚血発作後の虚 血性脳卒中再発予測}

国立病院機構九州医療センター 臨床研究センター 脳血管センター 脳血管・神経内科

○山城 貴之、桑城 貴弘、前田 花佳、
中西 泰之、中村 麻子、後藤 聖司、
矢坂 正弘、岡田 靖

【目的】一過性脳虚血発作患者におけるCCA ED ratioと虚血性脳卒中再発との関連について検討を行 う。

【方法】2007年6月から 2016 年 2 月にかけて、当院 脳血管センターに入院した脳卒中 3,100 症例のうち、 一過性脳虚血発作と診断された439例(男性279例、 女性 160 例、年齢 $68 \pm 13$ 歳)を対象とした。頸部血 管超音波検査で測定されたCCA ED ratioを4 群に分 け $(1 \leqq$ I群 $<1.2 、 1.2 \leqq$ II群 $<1.4 、 1.4 \leqq$ III群 $<1.6 、 1.6$ $\leqq I V) 、 I$ 群に対する各群の一過性脳虚血発作発症後 90 日間での虚血性脳卒中 (一過性脳虚血発作および 脳梗塞)の再発危険度を求めた。

【結果】90日間での虚血性脳卒中再発は44例 (9.2\%) に認められ、I群 22 例 (7.3\%)、II群 8例 (11.6\%)、 III群 4 例 (13.8\%)、IV群 10 例 $(25.6 \%)$ であった。年 齢および性別で調整を行ったCox比例ハザードモデ ル法による90日間の脳卒中再発危険度は、IV群に おいて Hazard ratio [HR]4.09、95\% confidence interval $[\mathrm{CI}] 1.85-8.43$ (vs. I群、 $\mathrm{p}=0.01$ ) であり、年齢、 性別に脳卒中危険因子を加えた多変量調整において も、IV群では[HR]4.7、95\% [CI]2.02-10.2 (vs. I群、 $\mathrm{p}>0.01$ ) と再発の危険度が高かった。

【結論】一過性脳虚血発作発症例においてED ratioが 高值の場合、その後の虚血性脳卒中再発の危険度が 高くなる。

\section{䅡動眽プラークの不安定化は「全身の炎 症」とよく相関している F-FDG PETに よる研究}

富山大学 医学部 脳神経外科

○柏崎 大奈、山本 修輔、秋岡 直樹、 桑山 直也、黒田 敏

【目的】内頚動脈狭窄症による脳血管イベントの発症 機序の多くは、不安定プラークが原因であり、プラー クの不安定化は、きわめて重要な病態である。プラー クの不安定化は、マクロファージを中心とした局所 炎症が主因であるが、プラークの不安定化を全身の 炎症から考察した研究は少ない。我々は、頚動脈プ ラークの性状と全身の炎症の関連を検討したので報 告する。

【方法】この前方視研究では、症候性内頚動脈狭窄 症のために頝動脈内膜剥離術を実施した8例とがん 検診を行った7例の健常人を対象とした。全例が男 性で、年齢はCEA群 $73.6 \pm 5.6$ 歳、健常群 $71.6 \pm 4.5$ 歳であった。全例でFDG PETを実施して、頚動脈、 脾臓、骨髄のSUVmaxを計測して2 群間で比較した。 また、CEA群ではプラーク標本を免疫染色に供し て、それぞれ活動性および成熟マクロファージの表 面マーカーであるCD11c、CD163の発現を額動脈プ ラークのSUVmaxと比較した。

【結果】 $\mathrm{T} 1$ 強調画像にて、頝動脈プラークは全例で 高信号であった。FDG PET上、䅡動脈のSUVmax はCEA群で $2.53 \pm 0.22$ と高值であった。脾臓のSU-

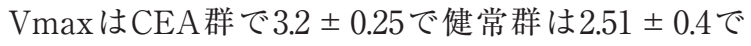
あった $\mathrm{P}=0.003$ 。また脾蔵/肝臓SUVmaxの相対值 はCEA群で $1.12 \pm 0.06$ 、健常群で $0.85 \pm 0.12$ であ た $\mathrm{P}=0.001$ 。一方、骨髄のSUVmaxはCEA群で 2.91 \pm 0.25 で健常群は $2.99 \pm 0.41$ でと有意差はなかった $\mathrm{P}=0.811$ 。頝動脈プラークでは、全例で活動性マク ロファージが成熟マクロファージよりも多く発現し ていた。

【結語】澒動脈プラークの炎症・不安定化と脾臓に代 表される「全身の炎症」とは有意に相関しており、全 身における慢性炎症は、内頚動脈狭窄症の抑制や発 症予防のための新たな治療の標的となる可能性があ る。 


\section{NASCET 50\%未満頚動脈狭窄症例に対 する血行再建術}

${ }^{1}$ 川崎医科大学付属病院 脳神経外科 $1 、{ }^{2}$ 川崎医科 大学付属病院 脳卒中科、 ${ }^{3} 川$ 崎医科大学付属病院 病理学 1

○高井 洋樹 ${ }^{1}$ 、小川祐佳里 ${ }^{1}$ 、佐藤 昂平 $^{1}$ 、 平井 聡 ${ }^{1}$ 、石原 学 ${ }^{1}$ 、原 慶次郎 ${ }^{1}$ 、 戸井 宏行 ${ }^{1}$ 、松原 俊二 ${ }^{1}$ 、宇野 昌明 ${ }^{1}$ 、 植村 順一 $^{2}$ 、八木田佳樹 ${ }^{2}$ 、西村 広健 $^{3}$

【目的】当院では頸動脈狭窄症例に対して、症候性 狭窄 $50 \%$ 以上と無症候性狭窄 $60 \%$ 以上に対しては CEAを第一選択で手術を施行し、CEAハイリスク 症例に対してはCASを施行している。今回は当院で 施行したNASCET 50\%未満の症候性病変に対する 血行再建について検討した。

【対象】 2009 年 4 月〜 2017年 4 月で当院脳卒中科と協 議の後、血行再建を施行した202例のうちNASCET 法で症候性狭窄 $50 \%$ 未満でCEAを施行した 22 例を 対象とした。

【結果】男性 20 例、女性 2 例で平均年齢は69.4歳 (58 〜 79歳)であった。NASCET法で狭窄率は平均 $29 \%$ であった。頸部エコーでのArea狭窄率は平均 $67.7 \%$ (44.5〜 97\%)であった。BB-MRIは19例で評価可能 であり、12例で不安定プラークが疑われた。造影頸 部エコーは21例施行し、11例 (52\%) で不安定プラー クが疑われた。術中所見ではCEA症例 20 例 (91\%) で不安定プラークを認めた。術後合併症は $1 / 4$ 盲の 1 例と前頭葉脳梗塞 1 例 (9\%) が出現したが、いずれ も自主生活に復帰している。追跡期間は平均 38 力 月（1〜 79か月）であった。経過中に再狭窄や脳卒中 となった症例はなかった。

【結語】以前の報告でも脳梗塞の発症と頸動脈狭窄 率とは相関がないとの報告がある。症候性軽度頸 動脈狭窄症でBB-MRIや造影頸部エコーでの不安定 と診断されたプラークは病理学的にも高率に不安 定プラークであった。しかし血行再建術でも minor strokeが約 10\%で出現したことを含め、手術は慎重 に行う必要がある。

\section{内頝動脈閉塞試験(balloon test occlu- sion : BTO)における合併症と妥当性の検 討}

岡山大学大学院 脳神経外科

$\begin{array}{rrrr}\text { ○木谷 } & \text { 尚哉、杉生 } & \text { 憲志、菱川 } & \text { 朋人、 } \\ \text { 平松 } & \text { 匡文、西廣 } & \text { 真吾、高橋 } & \text { 悠、 } \\ \text { 村井 } & \text { 智、伊達 } & \text { 勲 } & \end{array}$

【目的】当院での内頚動脈に対するBTOの成績、特 に合併症と検査の妥当性について報告する。

【方法】過去 26 年間に当科で施行した内澒動脈BTO 288例の合併症を検討した。BTO中に神経症状が出 現した場合にはBTO陽性としてその時点で検查を 中止し、30分間の遮断で症状出現がなかったものを 陰性と判定し、脳血流SPECTを併用した。2003年 以降の症例ではBTOの結果に基づいて行われた治 療の妥当性についても検討した。

【結果】年齢は20歳から88歳(平均58.1歳)。男性 112 例、女性 176 例。原疾患は内澒動脈瘤 162 例、頭澒 部腫瘍 98 例、外傷性CCF 15 例、内頝動脈狭窄症 13 例であった。BTO陽性例は 45 例、陰性例は 243 例で あった。永続的合併症として、バルーンカテーテ ルを留置した直後の広範な脳梗塞を 1 例に、検查終 了後に症状が出現した脳梗塞を3例にきたした。一 過性合併症として、バルーン拡張部血管攣縮 2 例、 TIA2 例、穿刺部合併症 1 例、腹部大動脈解離 1 例、 核種漏れ 1 例を認めた。BTO後に内澒動脈の永久閉 塞を施行したものは25例で、そのうち 14 例はBTO 陰性でSPECTでも血流低下を認めなかったため血 行再建を併用しなかったが、1例で術後脳梗塞を認 めた。BTO陰性でSPECTで血流低下を認めた8例 に対しては内頝動脈閉塞にSTA-MCA吻合術を併用 したものの、1例で術後脳梗塞を認めた。BTO陽性 で内頝動脈閉塞を行った 3 例はhigh flow bypassを 併用し、虚血性合併症を認めなかった。

【結論】今回のシリーズは過去の報告の合併症率と 比べても遜色なく、BTOは比較的安全で、治療方 針に有用な情報を提供すると考えられる。一方で、 BTO除性にも関わらず内頝動脈永久閉塞後に脳梗 塞となった症例も存在し、BTO結果の分析・手術 法決定には慎重な判断を要する。 


\section{内頝動眽狭窄症例における周術期脳血流 と過灌流に関する検討}

山梨大学 医学部 脳神経外科

$\begin{array}{rrr}\text { ○橋本 } & \text { 幸治、金丸 } & \text { 和也、吉岡 秀幸、 } \\ \text { 八木 } & \text { 貴、木内 博之 }\end{array}$

【目的】内頚動脈狭窄症の外科治療において、過灌流 症候群は重篤な合併症の一つであるが、その病態は 十分に解明されておらず、また対策も確立されてい ない。そこで、今回、血行再建術を施行した内䅡動 脈狭窄症例に㧍ける脳血流動態と過灌流に伴う頭蓋 内出血について検討したので報告する。

【方法】2008年より血行再建術を施行した頝動脈狭窄 症 101 例 107 側中、脳血流を詳細に検討した 46 側 46 例を対象とした。平均年齢73歳、男性 44側、無症 候性が11側だった。術前IMP SPECTで安静時CBF の対側比とCVRを測定し、CVR>30\%を0群、CBF $\leqq 80 \%$ かつCVR $00 \%$ II群、その他をI群に分類 した。II群では、過灌流回避のため段階的血行再建 術を施行した。脳血流は術翌日と1か月後に測定し、 術翌日CBF上昇率が $10 \%$ 以上の場合には、血圧管理 を厳重に行い、術後3-7日に再検查した。各群にお ける $\mathrm{CBF}$ の上昇率と過灌流症候群に伴う頭蓋内出血 との関連性について検討した。

【結果】0、IおよびI群はそれぞれ14、24および8側で、 CEAを 27 側に、CASを19側に施行した。術翌日の $\mathrm{CBF}$ 上昇率は、各群で有意差はなかった。 $\mathrm{CBF}$ 上昇 率が $10 \%$ 以上となったのは6例で、術後3-7日の 再検査では、CBFは低下していた。頭蓋内出血は0 とI群でそれぞれ1例ずつ発生し、術翌日のCBF上昇 率は20\%程度であった。また、段階的血行再建術施 行例では、頭蓋内出血を認めなかった。

【結語】過灌流高リスク群でも、段階的血行再建術に より安全に治療しえた。しかしながら、低リスク群 でも、術後のCBF上昇率が $20 \%$ 程度となった場合に、 頭蓋内出血を来たすことがあり、その機序の解明と 対策の確立が今後の課題である。

\section{術前7 Tesla 定量的磁化率マップ(QSM) によるOEF画像を用いた頸動眽内膜剥離 術後過灌流出現の予知}

1 岩手医科大学 医学部 脳神経外科、 ${ }^{2}$ 岩手医科大 学 医歯薬総合研究所 超高磁場MRI病態 - 診断部 門、 ${ }^{3}$ 北海道大学病院 放射線診療部、 ${ }^{4}$ 岩手医科大 学 医歯薬総合研究所 サイクロトロンセンター

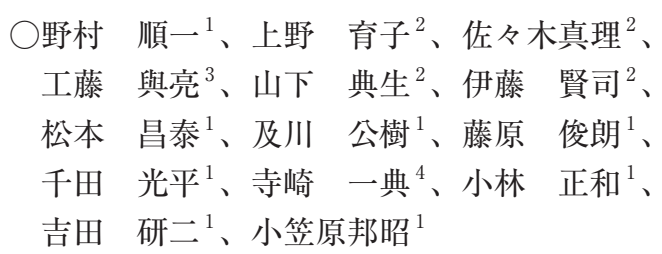

【背景】CEAの合併症の1つである術後過灌流の出 現には術前脳循環不全が関与していることが明らか になっている。臨床では、術後過灌流の予知とし て、Diamox 負荷脳循環測定が行われている。最近、 7T MR 高解像度磁化率イメージングから得られる QSM (quantitative susceptibility mapping)を用い たOEF画像がPET上でのOEF画像と相関すること が示された。

【目的】術前の7 TQSMを用いたOEF画像が、CEA 後過灌流の出現を予知できるかどうか検討した。

【方法】一側性内頚動脈狭窄症に対してCEA 前 に、7T MR高解像度磁化率イメージングを施行し、 QSM-OEF画像を作成する。3D-SRTを用いてQSMOEF画像を標準化し、中大脳動脈関心領域でQSMOEFの患側/健側比を求める。術前抢よび術直後後 に脳血流SPECTを行い、術後過灌流の有無を判定 する。QSM-OEFの患側/健側比が術後過灌流を予 知できるかどうか、統計学的に検討した。

【結果】これまで61例が登録された。術後過灌流は7 例 (11\%)であった。術後過灌流を持った症例 (1.178 $\pm 0.061)$ は、持たない症例 $(1.061 \pm 0.083)$ に比して 術前QSM-OEFの患側/健側比は有意に高かった $(\mathrm{P}$ $=0.0015)$ 。また、ROC解析では、術前QSM-OEFの 術後過灌流予知の精度は、感度 $100 \%$ 、特異度 $76 \%$ 、 陽性予測率 35\%、陰性予測率 100\% (cut-off = 1.090) であった。

【結論】術前の7 TQSMを用いたOEF画像は、CEA 後過灌流の出現を予知できる。 


\section{脳損傷周辺に集積するネスチン陽性活性 化アストロサイトは複数の由来を持つ}

\author{
神戸大学 大学院理学研究科
}

\section{中大脳動脈永久閉塞モデルにおける遠隔 虚血コンディショニングの効果}

東京女子医科大学 神経内科

○齋藤 萌子、石塚健太郎、北川一夫

【目的】一過性中大脳動脈閉塞に対する遠隔虚血コン ディショニングが再灌流障害を軽減させることは報 告しているが、今回は成熟マウスと老齢マウスを用 いて中大脳動脈永久閉塞モデルにおける遠隔虚血コ ンディショニングによる効果を神経症状、梗塞体積 より検証することを目的とした。

【方法】成熟C57BL6マウス (8 週齢) と老齢C57BLマウ ス (50週齢)を用いてイソフルレン吸入麻酔下で左 中大脳動脈 $(\mathrm{MCA})$ を露出させ、嗅索より MCA近位 部を閉塞した。24時間後に神経症状を観察し、脳 を摘出後TTC染色で脳梗塞体積を算出した。神経 症状は既報に基づき0 (症状なし) から5 (死亡) の6段 階で評価した。MCA閉塞から70分間の脳皮質血流 をレーザドプラ血流計でモニターした。遠隔虚血負 荷はMCA閉塞 30 分後から両側下肢を鼠径部でポリ エチレンチューブを用いて5分間駆血、5分間解放 を4回反復した。対照群は遠隔虚血負荷なし麻酔下 でMCA閉塞後70分間放置した群とした。なお、手 術中の体温は37度に保った。

【結果】成熟マウスの各群の残存血流は $20 \%-27 \%$ で群間に有意な差はみられなかった。24時間後の神 経症状は対象群、遠隔虚血群それぞれ中央值 $(25$ 75\%区間)が、1（1－2）、1（1－1）で群間に有意な 差はみられなかった。梗塞体積では、 $45.7 \pm 4.1 \mathrm{~mm}^{3} 、$ $35.7 \pm 3.8 \mathrm{~mm}^{3}$ で遠隔虚血群は対照群に対し有意に 差があった。一方、老齢マウスの各群の残存血流 は19\% - 27\%で群間に有意な差はみられなかった。 24 時間後の神経症状は対象群、遠隔虚血群それぞ れ中央值 (25 - 75\%区間) が、1（1－2)、1（1 - 2) で群間に有意な差はみられなかった。梗塞体積でも、 $36.7 \pm 6.2 \mathrm{~mm}^{3} 、 33.8 \pm 6.1 \mathrm{~mm}^{3}$ で群間に有意な差は みられなかった。

【結論】マウス中大脳動脈永久閉塞モデルにおいて、 成熟マウスでは遠隔虚血負荷の脳保護効果が観察さ れた。一方、老齢マウスでは遠隔虚血による脳保護 効果はみられなかった。 


\section{虚血性神経細胞障害におけるHAX-1の役 割}

山梨大学 医学部 脳神経外科

$\begin{array}{rcrc}\text { ○吉岡 } & \text { 秀幸、隋 } & \text { 欣、金丸 } & \text { 和也、 } \\ \text { 八木 } & \text { 貴、橋本 } & \text { 幸治、福田 } & \text { 憲人、 } \\ \text { 木内 } & \text { 博之 } & & \end{array}$

【目的】 HS-1 associated protein X-1 (Hax-1)はリン パ球のB細胞のシグナル伝達物質として発見された が、血液系細胞のみならず様々な細胞に発現し抗ア ポトーシス作用を有することが明らかとなってい る。しかしながら、これまで虚血性神経障害におけ る役割は十分に検討されていない。今回、in vivoと in vitroでの虚血性神経細胞障害におけるHAX-1の 発現動態を解析し、また、HAX-1発現抑制が神経 細胞障害に及ぼす影響についても検討した。

【方法】In vivo虚血モデルは雄性 C57BL/6野生型 マウスを用い、両側総澒動脈を 22 分間遮断し作成 した。虚血後3、6、24、72時間で断頭し、線条体 の蛋白抽出および薄切切片作成を行った。In vitro 虚血モデルには、PC12培養細胞の無酸素無糖条件 （OGD）を用い、OGD後6、9、15時間のサンプルを 作成した。HAX-1の発現はWestern blotおよび免疫 染色で解析した。In vitroでのHAX-1発現抑制には small-interfering RNA (siRNA)を用い、OGD後の 細胞障害はLDH assayで計測した。

【結果】HAX-1は非虚血下のマウス線条体では、神 経細胞のミトコンドリアに発現を認めた。脳虚血 後 3 時間よりミトコンドリアでのこの発現は徐々に 低下し、虚血後6-72 時間で有意差をもって減少した $(n=6 、 P<0.05) 。 一$ 方、細胞質分画では虚血後も 発現を認めなかった。HAX-1の発現低下はPC12細 胞でも認め、OGD後6-15時間で有意差をもって低

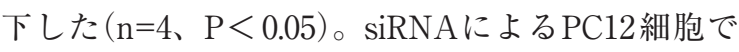
のHAX-1発現抑制は、OGD後の神経細胞障害を有 意に増悪した $(n=4 、 P<0.05)$ 。

【考察・結論】HAX-1は虚血性神経細胞障害に対し 保護効果を有し、その発現低下が虚血後アポトーシ スを誘導する。このミトコンドリア蛋白質が脳虚血 の新たな治療ターゲットとなりうるものと考えられ た。

\section{転写因子MafbはMSR1の発現を誘導して 炎症惹起因子を排除し、脳梗塞後の炎症 を収束させる}

${ }^{1}$ 東京都医学総合研究所脳卒中ルネサンスプロ ジェクト、 ${ }^{2}$ 福岡歯科大学 内科学講座、 ${ }^{3}$ 慶応義塾 大学医学部 微生物免疫学教室

○田 崇 ${ }^{1}$ 、大星 博明 ${ }^{2}$ 、吉村 昭彦 $^{3}$

脳梗塞後の炎症は、無菌的炎症の典型例である。 無菌的炎症では、組織傷害によって産生される DAMPsが炎症を惹起するが、無菌的炎症が収束す るメカニズムについては未解明である。HMGB1や ペルオキシレドキシンは脳梗塞後に生じるDAMPs であり、脳内に炎症細胞を浸潤させ、炎症を惹起す る。我々は、DAMPsが脳梗塞内のマクロファージ によって細胞内に取り达まれて排除されることを発 見した。マクロファージ様細胞株に高効率なランダ ム変異を導入し、DAMPsを取り込まない变異細胞 株を樹立した。これを用いてマイクロアレイ解析 を行い、DAMPs選択的なエンドサイトーシスに関 わる遺伝子としてMafb、Msr1、Marcoを見出した。 マクロファージは脳梗塞内に浸潤して数日後に転写 因子Mafb依存的に、スカベンジャー受容体MSR1 を高発現するようになり、DAMPsの積極的な排除 に関わる。MSR1を高発現するマクロファージは炎 症性サイトカインを産生せず、神経栄養因子IGF-1 を産生する修復担当細胞であった。Msr1/Marco欠 損マウスで脳虚血モデルを作製すると、脳梗塞内の DAMPsが排除されず炎症が悪化して、脳梗塞の拡 大や神経症状の悪化が観察された。ビタミンA誘導 体のタミバロテン $(\mathrm{Am} 80)$ は脳内マクロファージの MSR1 発現をMafb依存的に上昇させ、脳梗塞後の 炎症の収束を早め、脳保護効果を示した。次世代の 脳卒中医療には、脳に備わる修復機能を促進する薬 剤の開発が重要である。 


\section{マウス脳梗塞モデルに対する経口Xa阻害 薬投与が線維化・修復過程に与える影響}

\author{
九州大学 大学院医学研究院 病態機能内科学
}

○古森 元浩、立花 正輝、吉川 容司、 芝原 友也、山中圭、黒田 淳哉、 脇坂 義信、吾郷 哲朗、北園 孝成

【背景】脳梗塞発症後の組織修復は、PDGFR $\beta$ 陽性 細胞による梗塞内部線維化と梗塞周囲アストログリ オーシスが担い機能予後にも影響を及ぼしうる。ま た、活性化(凝固) 第X因子 (Xa) はProtease activated receptor (PAR) -1、2を介して、炎症や線維化 に関与するが、Xa阻害による脳梗塞修復過程への 影響は十分には知られていない。

【目的】脳梗塞発症後のXa阻害薬(リバーロキサバ ン)投与が組織修復に与える影響ついて検討した。

【方法】CB-17マウス (雄、8-13 週齢)を用いて中大脳 動脈遠位部永久閉塞モデルを作製し、PAR-1および PAR-2の発現を免疫染色で評価した。さらに、脳 梗塞作製後よりコントロール飼料群およびリバー ロキサバン (12000ppm) 混餌飼料群に分けて経過 観察した。4、7、10日目の脳梗塞巣 (MAP2 陰性 領域)の大きさ、10日目の梗塞周囲GFAP陽性領域、 PDGFR $\beta$ /Picro sirius red染色による線維化評価を 行った。また、 4 日目の梗塞半球におけるにおける 炎症性サイトカイン (TNF $\alpha$ 、IL-1 $\beta$ 、IL-6)、好中 球マーカー (CXCR1、2) およびマクロファージマー カー(CCR2)の発現をreal-time PCRで評価した。

【結果】PAR-1、PAR-2は脳梗塞巣内のPDGFR $\beta$ 陽 性細胞に発現していたがGFAP陽性アストロサイト には発現しなかった。脳梗塞巣の大きさは $4 、 7 、 10$ 日のいずれにおいても両群間で有意差はなかった。 一方、10日目における梗塞周囲GFAP陽性領域、梗 塞内部線維性応答は薬剤投与群において抑制されて いた。また、薬剤投与群においてCXCR1、2の発現 が有意に上昇しており、CCR2、さらにTNF $a$ 、IL-6 の発現量の上昇傾向を認めていた。

【結論】脳梗塞発症後のリバーロキサバン投与は、梗 塞内部炎症細胞浸潤を助長し、線維性応答およびア ストログリオーシスによる組織修復を阻害する可能 性が示唆された。

\section{マウス microsphere脳塞栓モデルにおけ る灌流圧変化と塞栓子分布の検討}

${ }^{1}$ 慶應義塾大学 医学部 神経内科、 ${ }^{2}$ 大阪市立大学 大学院医学研究科 神経内科

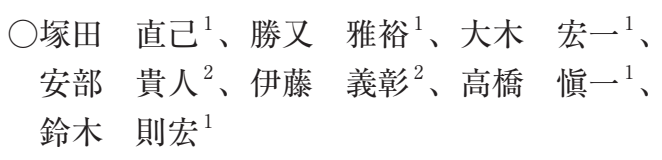

【目的】我々は2014年本学会総会で、マウス microsphere脳塞栓モデルを用いて境界領域梗塞における 塞栓性機序について検討し、塞栓子の粒子径と血管 径が分布パターンに影響し、特定粒子径の塞栓子が 有意に境界領域に集積することを報告した。今回、 1 ) 総頸動脈 $(\mathrm{CCA})$ 結紮を行わずに塞栓子注入を行 う通常灌流圧群と、2) CCAを結紮後に塞栓子注入 を行う低灌流圧群において、境界領域への分布率を 比較し、灌流圧の低下が分布パターンに与える影響 を比較検討した。

【方法】雄性C57BL/6 マウスを用い、1）CCA結紮 を行わず左外頸動脈 (ECA) にカテーテルを挿入し、 ECAを経由して内頸動脈 (ICA) に塞栓子を注入し た通常灌流圧群 $(n=5)$ と、2) 左CCA結紮後、CCA にカテーテルを挿入し、分岐部まで進め、ICAに塞 栓子を注入した低灌流圧群 $(\mathrm{n}=7)$ を比較した。直径 $13,24,40,69 \mu \mathrm{m}$ の 4 種類の蛍光microsphereを塞栓子 として用い、 $1 \times 10^{5}$ 個 $/ \mathrm{ml}$ の濃度で生理食塩水に懸 濁し、 $0.05 \mathrm{ml}$ 注入した。屠殺後に蛍光顕微鏡下で 脳表での分布を観察した。境界領域は、コントロー ルのマウスのCCAから $1 \mathrm{ml}$ の墨汁を注入後、脳を摘 出し脳表の中大脳動脈と前大脳動脈の接合部、中大 脳動脈と後大脳動脈の近接部を同定して設定した。

【結果】microsphereの境界領域への分布率(通常灌 流圧群 vs 低灌流圧群 \% ; mean \pm SD) は、31.1 \pm 7.0 vs $31.6 \pm 14.2$ (粒子径 $13 \mu \mathrm{m}) 、 56.2 \pm 15.7$ vs $58.7 \pm$ $7.4(24 \mu \mathrm{m}) 、 38.3 \pm 6.4$ vs $40.4 \pm 12.3(40 \mu \mathrm{m}) 、 11.6$ \pm 11.0 vs $14.2 \pm 12.8(69 \mu \mathrm{m})$ で両群に有意な差はな かった。

【考察】本モデルでは、塞栓子の分布パターンはCCA 結紮による灌流圧低下には影響されず、粒子径と血 管径によって規定されることが示唆された。 


\section{マウスを用いたくも膜下出血後認知機能 障害モデルの開発}

\author{
${ }^{1}$ 山口大学 医学部 脳神経外科、 ${ }^{2}$ マサチューセッ \\ ツ総合病院神経内科
}

岡 史朗 ${ }^{1,2}$ 、Ayata Cenk ${ }^{2}$ 、鈴木 倫保 ${ }^{1}$

【背景】脳動脈瘤破裂によるくも膜下出血患者の多く に認知機能障害が後遺する。その病態の解明およ び治療法の開発には優良な動物実験モデルが不可 欠である。今回我々はマウスを用いpre-chiasmatic cistern (PC) およびcisterna magna (CM)へのblood injectionによるくも膜下出血モデルを作成しその詳 細な生理学的変化、認知機能変化を検討した。

【方法】雄性、10-15週齢の C57BL6/Lマウスを使用 した。くも膜下出血はPCに対しては $40 \mu 1 、 C M に$ 対しては60 $\mu 1$ の動脈血を注入することで作成した。 対照群には生理食塩水を注入した。脳血流はlaser speckle flowmetryを用い注入後60分の変化を計測 した。頭蓋内圧および血圧も計測し注入中の脳灌 流圧も算出した。作成前㧍よび作成 2 週間後にPole test、novel object recognition test、Y mazeおうよび Morris water maze testを行い、神経学的変化、認 知機能変化を評価した。

【結果】脳灌流圧はどちらのモデルも注入直後に 65mHgから $10 \mathrm{mmHg}$ まで低下した。40mmHgに回 復するにはPCで平均 10 分、CMで平均 8 分を要した。 脳血流も血液注入直後に注入前と比べ $20 \%$ 以下まで の急激な低下が両側大脳半球に認められた。その後 徐々に改善し、 baselineの $40 \%$ にはPCで5分、CM で2分を要した。対照群では灌流圧および脳血流の 低下は程度が軽く短時間であった。注入 2 週間後に 行った運動・認知機能検査ではPC blood injection 群においてPole test、novel object recognition test、 Y maze testの結果が注入前もしくは対照群と比べ 有意に悪化していた。その一方 CM blood injection 群では有意な悪化を認めなかった。

【結語】Pre-chiasmatic cistern injection modelはく も膜下出血後認知機能悪化のモデルとなりうる。

\section{低酸素誘発性脳血管新生モデルマウスに おけるTSPO発現のPETによる検索}

${ }^{1}$ 量研機構 放射線医学総合研究所 脳機能イメージ ング研究部、 ${ }^{2}$ 量研機構 放射線医学総合研究所 分 子イメージング診断治療、 ${ }^{3}$ 福島県立医科大学 放 射線科、 ${ }^{4}$ 電気通信大学 脳科学ライフサポートセ ンター

○菅野 䉷 ${ }^{1}$ 、関 千江 ${ }^{1} 、$ 田桑 弘之 ${ }^{1}$ 、 金 朝暉 ${ }^{2}$ 、伊藤 浩 ${ }^{3}$ 、正本 和人 ${ }^{4}$

【背景と目的】低酸素誘発性脳血管新生モデルマウスで 低酸素飼育 1 週目以降での血管新生を光学的に確認し てきた。本研究では血管新生におけるTSPOの関連を 検討するため、PETによりTSPOが発現する時期を検 索した。

【方法】低酸素誘発性脳血管新生モデルマウスで低酸素 飼育0日（コントロール：D0)、4日(D4)、7日(D7)、14 日(D14)の時期毎にTSPOマーカーである11C-PK11195 のPETとARGを施行した。また、血管新生は、腫瘍 で確認しているインテグリン $\alpha \mathrm{v} \beta 3$ マーーカーの64Cu-cyclam-RAFT-c (-RGDfK-) 4 (64Cu-RAFT-RGD) の PET を施行した。これらを生化学的に検証するため、それ ぞれの時期毎の免疫化学染色(免染)を行った。TSPO 発現由来細胞を同定するため、Ibal（ミクログリア）、 GFAP（アストロサイト)、さらにTSPOの免染を行った。 な挍、血管新生についても血管内皮マーカーCD31とイ ンテグリン $\beta 3$ マーカーCD61の免染を施行した。

【結果】TSPOマーカーの11C-PK11195のPETでは30-60 分のSUVの評価で、D4だけ他時期より有意に高値を示 した。11C-PK11195のARGでもD4だけ有意に高い特異 結合を確認した。免染ではIbalとGFAPは全時期を通 してほほ均等な陽性信号を示した。その一方、TSPO染 色像ではD4で血管に沿った陽性像を示し、PETでのD4 のTSPO増加はグリア細胞由来ではなく、血管性TSPO の上昇であることが示された。なお、血管新生につい ては64Cu-RAFT-RGDのPETの投与 3 時間後のSUV值で 全ての時期・脳領域で有意な集積は見られず、免染で も内皮マーカーCD31は低酸素時期とともに陽性信号が 上昇したがCD61は全時期で陰性でPETの結果を追認し、 本脳血管新生モデルはPETの検出感度が低いか $a v \beta 3$ 以 外のインテグリン発現の可能性を示唆した。

【考察と結語】本モデルでは低酸素飼育早期D4にグリア 細胞由来でない一過性の血管性TSPOの上昇を確認し た。一過性の血管性TSPO発現とその後の血管新生と の関連は今後の研究課題となる。 


\section{B 1-integrin modulates cerebral microvascular tight junction expression and permeability}

${ }^{1}$ Division of Hematology, University of Washington School of Medicine, Seattle, Washington、USA（現 慶應義 塾大学 医学部 神経内科) 、 ${ }^{2}$ Division of Hematology, University of Washington School of Medicine, Seattle, Washington, USA（現 新潟大学 脳研究所 神経内科）、 ${ }^{3}$ Department of Molecular and Experimental Medicine, The Scripps Research Institute, La Jolla, California, USA, ${ }^{4}$ Stroke Branch, National Institute of Neurological Disorders and Stroke, Bethesda, Maryland, USA

\section{○伊澤 良兼 ${ }^{1} 、 Y u-H u a n \mathrm{Gu}^{1}$ 、長田 高志 ${ }^{1} 、$ 金澤 雅人 ${ }^{2}$ 、Brian T. Hawkins ${ }^{1}$ 、 James A. Koziol ${ }^{3}$ 、Thalia Papayannopoulou ${ }^{1}$ 、 Maria Spatz ${ }^{4}$, Gregory J. del Zoppo ${ }^{1}$}

脳血管障害および脳血管性認知症の高リスク患者では脳血管 透過性が妄進しており、その病態進展に関与している可能性 がある。我々は、脳血管内皮細胞と基底膜の結合に関わる $\beta 1$ インテグリンに着目し、血管透過性立進の機序について研究

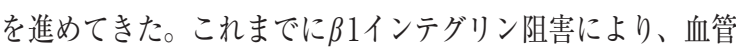
内皮細胞間のタイトジャンクションプロテインが減少し、透 過性が充進することを報告したが、その機序は不明であった。 今回、我々はマウス脳血管内皮細胞を用いて、 $\beta 1$ ンテグリン 阻害が細胞内シグナルに与える影響についてin vitroで評価を 行った。結果、 $\beta 1$ インテグリン阻害により、血管内皮細胞間 の透過性が増大する際、myosin light chain (MLC)のリン酸 化が立進することを確認した。MLCリン酸化に関与するRho kinaseおよびmyosin light chain kinaseを同時に阻害すると、 $\beta$ 1インテグリン阻害による内皮細胞間透過性元進は抑制され た。また、 $\beta 1$ インテグリン阻害により、細胞内アクチン構造 が変化したほか、claudin-5の細胞表面での発現が低下したが、 claudin-5の総発現量に変化を認めなかった。さらに、内皮細胞 間透過性が充進する条件下で、培養上清中MMP2、MMP9の 増加は観察されなかった。 $\beta 1$ イングリン・コンディショナ ルノックアウトマウスの脳内では、脳微小血管の透過性が立 進し、血管周囲の細胞外マトリックスが減少していた。これ らの結果は、 $\beta 1$ インテグリン-細胞外マトリックスの結合阻害 により、MLCリン酸化立進、アクチン細胞骨格の変化が生じ、 タイトジャンクションプロテインの分布変化を介して、血管 内皮透過性が杂進する可能性を示唆した。今回の研究で明ら

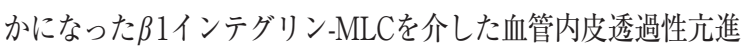
機序の更なる解明は、血管内皮透過性光進が病態進展に関与 する脳血管障害、多発性硬化症などの様々な神経内科疾患に おいて、病態理解や治療標的探索に寄与するものと期待される。

\section{発生期及び梗塞脳におけるVE-cadherin の発現に関する検討}

兵庫医科大学 先端医学研究所

○中込 隆之、土居亜紀子、佐久間理香、 松山 知弘

【緒言】脳血管内皮細胞は血液脳関門 (blood-brain barrier；BBB）を構成し、血管内物質の脳実質への 移行をコントロールしているが、内皮細胞同士の接 着にはtight junctionやadherens junctionが重要な 役割を果たしている。後者に関しては、cadherinファ ミリーの一つであるVE-cadherinの存在が知られて おり、VE-cadherinは内皮細胞の生存や集積、血管 透過性の調節などに関与することでBBBの機能維持 に関与するとされている。しかしながら、発生期及 び虚血病態時におけるVE-cadherinの動態について はよく知られていない。そこで、今回、我々は発生 期及び梗塞脳におけるVE-cadherinの発現を中心に 検討した。

【方法】胎生期 17 日目 (E17)、生後1日(P1)、15日 (P15)、成体期 (5 週齢、24 週齢) の発生期マウスの 脳切片、および成体期 ( $8 、 24$ 週齢) の脳梗塞マウス の脳切片を作製して、VE-cadherinとCD31に対する 免疫組織化学染色を行った。また、VE-cadherinの promoterの活性化により、YFPを発現する遺伝子 改変マウスを作製して、脳梗塞後のYFP発現及び YFP発現細胞の特性に関しても検討した。

【結果】免疫組織化学染色の結果、CD31は発生期及 び成体期のいずれの時期においてもその発現を認め た。一方、VE-cadherinは発生期において、その発 現が一時的に増強したものの、成体期には、その発 現は減弱した。しかしながら、脳梗塞後には、虚 血領域においてVE-cadherinの発現が再び増強した。 遺伝子改変マウスを用いた検討においても、脳梗塞 により、虚血領域を中心にYFP陽性細胞の発現が増 強し、YFP陽性細胞の多くは、CD31陽性血管内皮 細胞であることが明らかとなった。

【結論】VE-cadherinは、成体期には、その発現が 減弱するものの、虚血負荷により、梗塞領域の血管 内皮細胞において、その発現の増強を示したことよ り、VE-cadherinは脳梗塞領域のBBBの機能に対し て、何らかの影響を与えていることが示唆された。 


\section{Blood-Brain Barrierに対するHemoglo- bin関連分子の影響}

${ }^{1}$ 岐阜薬科大学 薬効解析学研究室、 ${ }^{2}$ 岐阜薬科大学 薬化学研究室

$\bigcirc$ 今井 貴彦 ${ }^{1}$ 、岩田 星菜 ${ }^{1}$ 、平山 祐 ${ }^{2} 、$ 永澤 秀子 ${ }^{2}$ 、嶋澤 雅光 ${ }^{1}$ 、原 英彰 ${ }^{1}$

【背景・目的】脳出血などの出血性脳卒中において は、血管破綻により血管外へ漏出した血液が二次障 害を引き起こすが、その機序として、血腫中のHemoglobin $(\mathrm{Hb})$ やその分解産物であるへム、鉄によ る酸化ストレスの惹起やカスパーゼ経路を介した神 経細胞死の誘発が報告されている。 $\mathrm{Hb}$ の神経毒性 に対する検討は数多く行われているが、血管自体へ の影響に関しては未だ不明な点が多い。そこで我々 は、血液脳関門 $(\mathrm{BBB})$ において重要な役割を担う脳

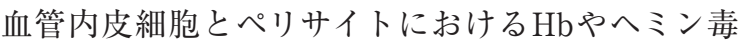
性並びに、in vivoにおけるへミンのBBBへの影響に ついて検討した。

【方法】In vitroの検討においては、ヒト脳毛細血管 内皮細胞 (HBMVECs) とペリサイト (HBMVPs)に ヒト Hbまたはへミンを負荷し、死細胞評価、活性 酸素種 $(\mathrm{ROS})$ 産生評価、膜電気抵抗及び透過性試験 による内皮機能の評価、ウエスタンブロット法によ る各種タンパク質の発現量への影響の評価を行った。 $\mathrm{Hb}$ やミン障害への鉄の関与について検討するた め、鉄認識蛍光プローブを用いて細胞内鉄蓄積を評 価した。また、鉄キレート剤であるbipyridyl (BP) の併用による影響を評価した。In vivoにおいては、 ヘミン脳実質投与 1 日後、 3 日後におけるBBB透過 性立進について評価した。

【結果】In vitroにおける $\mathrm{Hb}$ やミン負荷は、両細 胞で細胞死の誘発、ROS産生立進、内皮細胞のバリ アー機能の低下、 heme oxygenase-1 (HO-1)の上昇 などを誘導した。さらに、細胞内への鉄蓄積の上昇 も確認された。細胞死誘発やROS産生立進は、鉄キ レート剤の処置により抑制されたが、Hb処置後の 鉄蓄積は抑制されなかった。In vivoにおいては、へ ミン投与で 1 日後及び 3 日後のBBB透過性充進と神 経症状の発現が認められた。

【結論】出血後に出現するHbやその分解物は、内皮 細胞やペリサイトに直接的な細胞死を誘発すること によりBBBに障害を与え、その機序はへムの細胞内 蓄積が関与していることが示唆された。

\section{新規過灌流ラットモデルにおける血液脳 関門破綻機序に関しての検討}

${ }^{1}$ 秋田大学大学院医学系研究科脳神経外科学講 座、 ${ }^{2}$ 東北大学大学院医学系研究科 神経外科学講 座

○古山 陽佑 ${ }^{1}$ 、新妻 邦泰 $^{2}$ 、Ahmed Mansor ${ }^{2}$ 、 清水 宏明 ${ }^{1}$ 、冨永 悌二 ${ }^{2}$

【背景】頚部頚動脈血栓内膜剥離術やSTA-MCA bypass術の重篤な術後合併症の1つとして過灌流症候 群が知られる。その病態は脳血管の自動調節能障害 が主因と考えられているが、病理学的検討含め発生 メカニズムは完全には明らかとなっていない。

【目的】新規の実験的過灌流モデルを作成し、病理学 的検討ならびに炎症関連物質の蛋白定量解析、行動 解析手法を用い過灌流病態を明らかにすることを目 的とする。

【方法】8-9週齢の雄性 Sprague-Dawlay ラットの一 側総頸動脈を 6-0絹糸で結紮し、対側総頸動脈を needleとともに6-0 絹糸で結紮、直ちにneedleを抜 去し狭窄させた低灌流モデルを作成した。術 3 日後 に同モデルの狭窄側を解除して過灌流モデル(H群) を作成し、再灌流後の脳血流の継時的変化をLaser speckle flowmetryを用いて評価した。また対照群 として上記低灌流モデルを術 24 時間後に狭窄解除 したモデル (C群)を作成し再灌流 1 日後、3 日後、 7 日後のH群およびC群の脳組織をTTC染色、HE染 色、Kluver-Barrera染色および抗GFAP ・ MMP-9 抗体を用いた蛍光免疫染色を施した。次に血液脳関 門保護効果が報告されるスフィンゴシン 1 リン酸受 容体調節薬であるFTY720、1mg/kg H 群の再灌 流直前に腹腔内投与し、saline群、vehicle群と比較 した再灌流 11 日時点での治療群の位置記憶学習を burnes maze testを用いて評価した。

【結果】H群で再灌流24-72 時間後にLaser speckle flowmetryを用いた脳血流評価で両側頭頂葉に高灌 流を認めた。蛍光免疫染色ではH群再灌流 1 日後の大 脳皮質閉塞側においてMMP-9の強発現が示唆された。 burnes maze testでは非治療群と比較しFTY720投与 群で位置記憶学習の改善傾向がみられた。

【結語】新規脳過灌流モデルは、現在報告される選択 的中大脳動脈閉塞/再灌流モデルと比較しより術後 病態に近いと考えられ、同モデルを用いた再灌流後 の組織検討や行動解析により過灌流予防治療の一助 となる可能性がある。 


\section{活性酸素消去剤封入ナノ粒子(RNP)によ る脳虚血再灌流障害に対するNeurovas- cular unit保護療法}

${ }^{1}$ 筑波大学 医学医療系 脳神経外科、 ${ }^{2}$ 筑波大学 数 理物質科学研究科、 ${ }^{3}$ 筑波技術大学 東西統合医療 センター、 ${ }^{4}$ 獨協医科大学越谷病院 脳神経外科

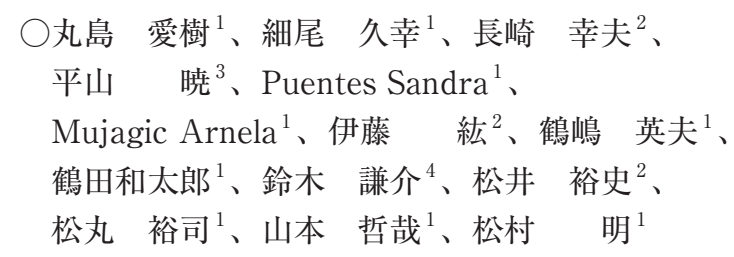

【はじめに】脳主幹動脈閉塞急性期における再開通療 法の有効性は明らかだが、再開通療法後に発生する 活性酸素による脳虚血再灌流障害は、脳梗塞拡大や 出血性合併症を起こし、治療転帰を悪化させる。そ の為、脳虚血灌流障害を防ぐための新たな脳保護療 法の開発が必要である。本報告では、活性酸素消去 剂封入ナノ粒子 (RNP : Radical containing nanoparticles）を、一過性中大脳動脈閉塞モデルに頸動脈投 与し、Neurovascular unit保護効果とその作用機序 を検証した。

【方法】マウス一過性中大脳動脈閉塞モデルにおいて、 再開通20分後に薬剤を頸動脈投与した。 $24 \mathrm{~h}$ 後に RNPの脳梗塞巣における分布、脳血管保護効果、脳 梗塞体積抑制効果、中枢神経細胞のフリーラジカル 産生、DNAの酸化損傷、アポトーシス評価、及び、 摘出脳の抗酸化能の評価を行った。

【結果】平均粒径 $40 \mathrm{~nm}$ のRNPは脳血管壁のみならず、 血管外腔への分布を認め、一過性脳虚血より透過性 が立進した血液脳関門を通過し、中枢神経細胞周囲 に分布した。有意にEvans blueの漏出を抑制し、血 液脳関門を保護するとともに、脳梗塞を減少させた。 神経細胞内のフリーラジカルの産生、DNAの酸化 損傷、及びアポトーシスを抑制した。RNP投与群の 脳は、・O $2 、$ ROO、・O $2-$ に対する抗酸化能が高 かった。

【考察と結語】脳虚血再灌流後に頸動脈投与された RNPは、血液脳関門を通過し、脳血管のみならず 中枢神経細胞に対するNeurovascular unit保護効果 を発揮し、脳虚血再灌流障害を抑制すると考えら れた。(Hosoo、Marushima、 et al. Stroke 2017、in press)

\section{活性化プロテインC (APC)の脳梗塞縮小 効果とそのメカニズム : マウスを用いた検 討}

${ }^{1}$ 国立循環器病研究センター研究所疾患分子研究 室、 ${ }^{2}$ 国立循環器病研究センター研究所 分子病態 部、 ${ }^{3}$ 国立循環器病研究センター 脳神経外科

○大和 恵子 ${ }^{1}$ 、中城有香子 ${ }^{1}$ 、
井本 (山本) ひとみ ${ }^{2}$ 小亀 浩市 ${ }^{2}$ 、
宮田 敏行

プロテインC (PC、未活性化型)に関する過去の前向 き臨床試験により、その血漿濃度が高值の群で虚血性 脳卒中の発症率が有意に低かった、との事実より、活 性化型PC (APC) が虚血性脳傷害に対する脳保護効果 を有する可能性がある。深部静脈血栓症、急性肺血 栓塞栓症、電撃性紫斑病の治療にすでに使用されて いるヒトAPC (アナクトC、化血研)の脳梗塞進展に 及ぼす効果 ; 脳保護効果の有無、および、それに対 するプロテアーゼ活性化受容体(PAR) -1アンタゴニ スト：SCH79797 (SCH) 投与の影響を検討した。雄性 C57BL/6Jマウスに独自に開発した3血管閉塞(3-VO) 手技(Yangら、15分間虚血、2014)を施し、ヒトAPC $0.25 、 0.5 、 1 、 2 、 4 、 8 \mathrm{mg} / \mathrm{kg}$ 、対照群として、抗凝

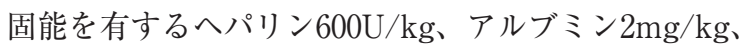
または生食を、虚血開始5分後、3時間後(急性実験)、 または虚血開始5分後、3、24、48、72 時間後(慢性実 験)に静脈内投与し、SCH投与群では、虚血開始 1 時 間前に腹脘内へ投与した。虚血前/中/後の局所脳血流、 運動機能、急性期 (24時間後)または慢性期 (7日後)の 脳梗塞体積を測定した。APC $0.5 \mathrm{mg} / \mathrm{kg}$ の投与は、虚 血中の脳血流に影響を与えることなく、脳梗塞進展お よび運動機能障害を有意に抑制した。一方、ヘパリ ンおよびアルブミンは脳梗塞体積を抑制せず、さら に、SCHの虚血前投与はAPCの脳保護効果を打ち消 した。過去の塞栓糸挿入モデル (ITI)を用いた脳保護 効果の判定で、 APC $2 \mathrm{mg} / \mathrm{kg}$ が有効であったとの報告 があるが、ITIでは単なる抗凝固物質であるへパリン 600U/kgの急性期投与も有効であり、APCが有する抗 凝固作用が、栓糸 (異物)の血管内挿入を起因とする血 液凝固を抑制し、それが局所脳血流を改善し、その結 果、脳梗塞の進展が抑制された可能性がある。本研究 で示されたへパリン非有効モデルにおけるAPCの脳 梗塞縮小効果は、APCの有する、PAR-1活性を介した、 脳神経保護作用と考えられる。 


\section{新規過酸化脂質代謝産物スカベンジャー； CNN (Lーカルノシンヒドラジド)の脳虚 血神経細胞障害保護効果}

${ }^{1}$ 久留米大学医学部 脳神経外科、 ${ }^{2}$ 熊本大学薬学部 生体機能分子合成学分野

\author{
○野口慶 ${ }^{1}$ 、折戸 公彦 ${ }^{1}$ 、三好 淳子 ${ }^{1}$ 、 \\ 森岡 基浩 ${ }^{1}$ 夕夕 シュハタアリ ${ }^{2}$ 、 \\ 藤田美歌子 ${ }^{2}$ 、大塚 雅巳 $^{2}$
}

【はじめに】脳梗塞の急性期に、虚血脳に血流が再開 通すると酸素フリーラジカルが急増し、脂質過酸化 が促進される結果、過酸化脂質から細胞毒性アル デヒド 4 - ヒドロキシノネナール (4-Hydroxynonenal：HNE) が生成される。HNEは、生体内では、 脂質過酸化が促進された際に、過酸化脂質から生成 される細胞毒性アルデヒドであり、タンパク質のア ミノ酸残基と架橋することによって細胞毒性を示す ことが明らかにされている。今回我々はHNEを捕 捉又は消去する活性を有する新規化合物 $\mathrm{CNN}$ (ヒス チジン誘導体：L－カルノシンヒドラジド)を開発 合成し、虚血脳に対する神経保護作用について検討 したので報告する

【方法と結果】1）CNNおよび、既知のカルノシン 誘導体それぞれにおいてHNE補足反応を比較した ところ、 CNNが最も強力な HNE捕捉物質であっ た。2) $\mathrm{HNE}(250 \mu \mathrm{M})$ 及び本 CNN $(0 \mu \mathrm{M} 、 100 \mu$ $\mathrm{M} 、 1 \mathrm{mM}$ 又は $10 \mathrm{mM})$ の存在下で $\mathrm{PC}-12$ 細胞に対す る $\mathrm{HNE}$ 誘導性細胞死抑制効果を検討した。CNNの 非存在下で、PC-12細胞はほぼ全ての細胞が死滅す るが、CNN 10mMの存在下では、70\%以上の細胞 が生存した。3) スナネズミ両側内頸動脈閉塞モデ ル(5分間)における海馬CA1 細胞Delayed neuronal death (DND) の抑制効果を検討した。虚血20分前 $\mathrm{CNN} 20 \mathrm{mg} / \mathrm{kg}$ 腹腔内投与、及び虚血解除直後CNN $100 \mathrm{mg} / \mathrm{kg}$ にてDNDが有意に抑制されていた。

【結論】我々の新規に開発した過酸化脂質代謝物質 HNE 補足物質CNNは脳虚血による神経細胞障害抑 制効果を持つと考えられる。またその作用は、現在 報告されている他のカルノシン誘導体よりも効果的 であると考えられる。

\section{新規脳梗塞治療薬SMTP-7の開発}

${ }^{1}$ 東北大学 大学院 医学系研究科 神経外科学分 野、 ${ }^{2}$ 広南病院 脳神経外科、 ${ }^{3}$ 秋田大学 大学院 医 学系研究科 脳神経外科学講座

$\bigcirc$ 新妻 邦泰 ${ }^{1}$ 、藤村 幹 $^{2}$ 、清水 宏明 $^{3}$ 、

冨永 悌二 1

SMTP-7は、プラスミノーゲンの活性化を促進し血 栓を溶解させる一方で、細胞内において可用性エポ キシドハイドロラーゼを阻害し抗炎症活性・組織保 護作用も示す薬剤である。2つのメカニズムを併せ 持つことにより、虚血再灌流に関連する合併症を軽 減しながら再開通を得られ可能性があり、脳梗塞に 対する治療効果が期待される。特に、tPAや血管内 治療の適応を狭める症候性頭蓋内出血を抑制する可 能性があり、これらの適応外となる患者群を治療で きる可能性がある。我々は、SMPT-7の臨床応用を 目指し前臨床試験を重ねてきた。SMTP-7は脳梗塞 モデルにおいては、有意に梗塞体積を減少し、神経 症状も改善した。tPAと比較すると、発症 3-6 時間と、 投与時間が遅くなっても神経症状や脳梗塞体積を改 善することが明らかになった。脳塞栓モデルに対し てtPAとSMTP-7の効果を比較すると、tPAでは急 速に脳血流量が回復したことと対照的に、SMTP-7 投与群では、24時間までにかけて徐々に脳血流量 が改善した。また、ワーファリンを投与することに よりINRを高值にした上で一過性中大脳動脈閉塞を 負荷したモデルでは、tPAやvehicleで治療した群で は重度の出血性変化を認めたが、SMTP-7投与群で は出血性変化の有意な減少と神経症状の改善を認 め、出血のリスクが高い病態でもSMTP-7は安全に 治療できる可能性があることが示唆された。以上か ら臨床に橋渡しを進めており、SMTP化合物につき 第一相治験まで終了した。健常者に静脈内投与した が、明らかな有害事象を認めなかった。凝固系検査 ではフィブリノーゲンやアンチプラスミンの減少を 認めず、出血リスクが低いことを説明する所見と考 えられた。本薬剤を臨床応用すべく、第二相治験を 予定している。 


\section{0-4}

\section{レビー小体病の疾患修飾治療薬の開発}

東北大学大学院 薬学研究科 薬理学分野

$\bigcirc$ 福永 浩司、矢吹 悌、泉 久尚、
篠田 康晴

レビー小体病は認知機能の変動、繰り返し出現する 幻視、パーキンソン症状を呈する疾患である。アル ツハイマー病、血管性認知症についで多い認知症で ある。根本治療薬はない。私達は $\alpha$ シヌクレインの オリゴマー形成に脂肪酸結合タンパク質 $(\mathrm{FABP})$ が 関与することを報告した (J Biol Chem 2014; 289 ： 18957)。中でもFABP3は黒質ドパミン神経に高発 現し、MPTPなどのパーキンソン病を発現する薬 剂を投与すると、黒質ドパミン神経において クレインとオリゴマーを形成して、神経細胞死に 関与している。本研究ではFABP3 阻害薬を探索し て、レビー小体病の疾患修飾治療薬の開発を目指 す。マウス脳にはFABP3、FABP5、FABP7が主に 発現し、FABP7は自閉症や統合失調症などの神経 発達障害に関係することが遺伝子久損マウスで証 明されている。FABP3は心臓に多く発現している が、FABP3 欠損マウスでは不安行動の克進以外に、 特異な症状は見られない。脂肪酸結合夕ンパク質 は脳以外に FABP4が脂肪組織などの高発現してい る。私達は、最初にFABP3に選択性の高いリガン ドを探索し、細胞系において $\alpha$ シヌクレインのオリ ゴマー形成を抑制するリード化合物を選択した。次 に、MPTP投与によりパーキンソン病を誘発したマ ウスを用いて、運動機能障害と認知機能障害に対す るFABP3リガンドの効果を検討した。FABP3リガ ンドは用量依存性にMPTP投与マウスの運動機能障 害を改善し、認知機能も改善した。組織化学による 検討においてもFABP3リガンドは黒質ドパミン神 経の細胞死を有意に抑制した。今後は薬物動態試験、 毒性試験を行う前臨床試験を実施する。本研究は日 本医療研究開発機能の支援により実施された。

\section{0-5}

\section{ラット慢性脳虚血モデルに対するHMGB1 投与を併用した間接バイパス術の治療効 果の検討}

\author{
岡山大学大学院 脳神経外科 \\ ○西廣 真吾、菱川 朋人、杉生 憲志、 \\ 平松 匡文、木谷 尚哉、高橋 悠、 \\ 村井智、伊達 勲
}

【目的】我々はこれまで、ラット慢性脳虚血モデルを 用いて脳表に側頭筋を接着させる間接血行再建術 (encephalo-myo-synangiosis : EMS)を行い、もや もや病手術モデルを作成し、血管新生が増加するこ とを報告してきた。今回、血管新生促進作用のある high mobility group box-1 (HMGB1) 投与を併用し たEMSの治療効果について検討した。

【方法】9週齢の雄性Wistar ratを使用し、両側総 䅡動脈を結紮し1週間後に側頭筋にHMGB1を筋注 後、EMSを施行した。HMGB1 投与群(投与量 $: 1 \mu$ g) と control群 (EMSのみ施行)で治療効果を比較し た。EMS施行後2週目に脳を摘出し、脳組織切片 を作成後、抗CD31抗体を用いて免疫染色を行った。 染色された脳表の血管数を計測し2群間で比較した。 EMS施行後 4 日目に脳、側頭筋を採取し、ELISAを 用いてVEGF濃度を測定し2群間で比較した。EMS 施行後 2 週目に小動物用SPECTを用いて、 ${ }^{123}$ I-IMPSPECTを撮影し、EMS施行部位の大脳皮質と非手 術側の大脳皮質にそれぞれ関心領域を設定して脳血 流を比較した。

【結果】HMGB1 投与群の手術側における脳表の血 管数は、control群と比較して増加し、投与群の非 手術側と比較して有意な増加を認めた $(\mathrm{p}<0.01)$ 。 HMGB1 投与群の手術側に抢ける側頭筋のVEGF 濃度は、control群と比較して上昇し、投与群の非 手術側と比較して有意な上昇を認めた $(\mathrm{p}<0.05)$ 。 SPECTではEMS直下の大脳皮質で、非手術側と比 較してhotに描出され、投与群における脳血流比 (手 術側/非手術側)はcontrol群と比較して増加した。

【結論】EMSにHMGB1投与を併用することで脳表 の血管新生が促進され、脳血流の改善に寄与してい た。HMGB1 投与により、VEGFを介して血管新生 が促進されることが示唆された。 


\section{T型カルシウムチャネル賦活薬SAK3によ

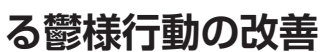

東北大学大学院 薬学研究科 薬理学分野

○矢吹悌、于 梦澤、許晶、 福永 浩司

【目的】新規アルツハイマー病治療候補薬である ST101はT型カルシウムチャネル賦活化し、認知 機能を改善する。ST101の臨床試験(Phase IIa)で は単独での効果が弱いため、私達はST101誘導体 の中からより活性の強いSAK3を創製した $(\mathrm{PCT} /$ JP2013/51388)。SAK3はアセチルコリン (ACh) 神経 系に発現しているT型カルシウムチャネルを賦活化 し、ACh遊離を促進し認知機能を改善する (Yabuki Y et al.2017. Neuropharmacology. $117: 1$-13.)。本 研究では、SAK3の嗅球摘出 $(\mathrm{OBX})$ マウスにおける 認知症精神行動症状 (BPSD) 様行動改善作用とその 作用メカニズムを検討した。

【方法】8週齢の雄性ddYマウスの嗅球を摘出し、2週 間後からSAK3 $(0.1 、 0.5$ or $1.0 \mathrm{mg} / \mathrm{kg} 、$ p.o.)を1日 1 回 2 週間経口投与した。行動薬理試験により、うつ 様行動を評価した。行動試験終了後、マウス脳を摘 出し、免疫ブロット法により細胞内情報伝達を解析 した。また、7日間BrdU (50mg/kg、i.p.)を投与し、 海馬歯状回における神経新生を評価した。

【結果】SAK3投与により、OBXマウスにおけるう つ様行動が改善した。OBXマウスの海馬歯状回で は神経新生が低下しているが、SAK3投与により 有意に改善した。SAK3 $(0.5 \mathrm{mg} / \mathrm{kg} 、$ p.o. $)$ 投与は、 OBX マウス海馬歯状回で低下したCaMKII/CaM$\mathrm{KIV} / \mathrm{CREB}$ シグナルを改善し、BDNF シグナルを 立進した。これらSAK3 $(0.5 \mathrm{mg} / \mathrm{kg} 、$ p.o. $)$ 投与によ る改善作用はT型カルシウムチャネル選択的阻害薬 NNC 55-0396 (12.5mg/kg、i.p.)により有意に抑制さ れた。

【目的】SAK3はT型カルシウムチャネルを賦活化し、 神経新生を促進することでOBXマウスのBPSD様行 動を改善することがわかった。海馬歯状回におけ るM1ムスカリン性ACh受容体および $\alpha 7$ ニチン性 $\mathrm{ACh}$ 受容体活性化は神経新生促進を促進することか ら、SAK3はACh遊離促進を介し、OBXマウスの神 経新生を改善すると考えられる。

\section{一側性脳主幹動眽閉塞性病変に対する ${ }^{99 m}$ Tc-ECD SPECTの貧困灌流検出能}

岩手医科大学 脳神経外科

○松本 昌泰、千田 光平、及川 公樹、
小島 大吾、藤原 俊朗、小林 正和、
吉田 研二小笠原邦昭

【背景】脳主幹動脈の慢性狭窄・閉塞性病変におけ る貧困灌流の検出には、本邦では123I-IMP SPECT が用いられている。しかし、国際的には ${ }^{99 \mathrm{~m}} \mathrm{Tc}-\mathrm{ECD}$ SPECTが一般的であるが、 ${ }^{99 \mathrm{~m}} \mathrm{Tc}-\mathrm{ECD}$ SPECTにお ける貧困灌流の検出精度を多数例で検討した報告は 存在しない。一方、Crossed cerebellar hypoperfusion とは病変側大脳半球の対側小脳半球のCBF低下 と定義され、病変側大脳半球の相対的な代謝量を表 すことが知られている。

【目的】本研究ではPETを対照として、貧困灌流を推 定するための ${ }^{99 \mathrm{~m}} \mathrm{Tc}-\mathrm{ECD}$ SPECTの至適条件・解析 法を見出すことを目的とする。

【方法】対象症例は脳主幹動脈の一側性慢性狭窄 - 閉 塞性病変 97 例とした。PETにより CBF、CMRO2、 OEF画像を作成、また ${ }^{99 \mathrm{~m}} \mathrm{Tc}-\mathrm{ECD}$ SPECTを施行し た。両側中大脳動脈域と両側小脳半球に関心領域を 置き、それぞれ患側/健側比 (ARMCA)、健側/患側 比 (ARcbl)を算出した。

【結果】PET CBFおよびCMRO2のARMCAと ${ }^{99 \mathrm{~m}} \mathrm{Tc}$ ECD SPECT の ARMCA おょよび ARcbl は、 ${ }^{99 \mathrm{~m}} \mathrm{Tc}-$ $\mathrm{ECD}$ 投与後の 20-30分の収集で最も相関し、相関 係数はそれぞれ0.654、0.576であった。貧困灌流 (PET OEFのARMCA 高值) 検出能は、 ${ }^{99 \mathrm{~m}} \mathrm{Tc}$-ECD SPECTのARMCA単独 (AUC : 0.780) に対し、ARcbl/ARMCA（AUC：0.947）で有意に大きかった $(\mathrm{P}=0.0001)$ 。

【結論】脳主幹動脈の一側性慢性狭窄・閉塞性病変に おける貧困灌流は、 ${ }^{99 \mathrm{~m}} \mathrm{Tc}-\mathrm{ECD}$ SPECTにおけるト レーサ投与後 20-30 分の大脳半球 - 小脳半球左右比 の組み合わせにより高い精度で検出しうる。 


\section{頸動脈ステント留置術前後での頭部MRI ASL所見とSPECT所見の比較}

福岡県済生会福岡総合病院 神経内科 脳 - 血管内科

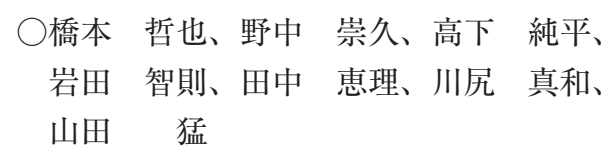

【目的】Arterial Spin Labeling (ASL) は動脈血中の プロトンを電磁気的にラベルし灌流像を得る頭部 MRI撮像法で、非侵襲的で迅速な点で脳血流の定量 評価法として有望だが、信号雑音比が低くアーチ ファクトに注意が必要である。今回、頸動脈ステン 卜留置術 (CAS) 前後でASL法による脳血流評価を 行い、CAS前後でのSPECT所見と比較した。

【方法】当院にて 2017 年 1 月から6月にCASを施行し、 術前後に頭部MRI ASL法とSPECTを撮像した連続 14例を対象とした。ASL法は1.5T MRI撮像装置に て撮像法 : Pulsed ASL、アルゴリズム：Q2TIPSを 用い, post labeling delayを1.3秒に設定し全脳の画 像を撮像した。SPECTは ${ }^{123} \mathrm{I}$-IMP $111 \mathrm{mBq}$ を投与し 10 分後に動脈採血を行いdual auto-radiography法で 定量評価を行った。ASL画像、SPECT画像の患側 · 健側の中大脳動脈領域に関心領域を設定して脳血流 の患側/健側比を測定し、術前後で両画像を比較した。 【結果】対象 14 例は年齢 $72 \pm 6$ 歳、女性 2 例、症候 性 3 例であり、術後に過灌流症候群を来した症例 はなかった。CASにより狭窄率はNASCET法にて $79 \pm 14 \%$ から $26 \pm 13 \%$ に改善した。脳血流の患側 /健側比のCAS前後での変化は、ASL : $99 \pm 42 \%$ $\rightarrow 84 \pm 23 \%(\mathrm{p}=0.08) 、$ SPECT $: 96 \pm 11 \% \rightarrow 98 \pm$ $9 \%(\mathrm{p}=0.75)$ であり、ASLの変化とSPECTの変化 には正相関の傾向を認めた(勾配0.088、 $\mathrm{r}^{2}=0.27$ 、 $\mathrm{p}=0.055)$ 。脳血流の患側/健側比のCAS前の ASL と SPECTの差は、CAS後のASL と SPECT の差と 有意な正の相関関係を認めた(勾配 $0.35 、 r^{2}=0.34$ 、 $\mathrm{p}=0.03)$ 。

【結論】1.5T MRI撮像装置でのASL法によるCAS前 後での脳血流変化は、SPECTと同様の変化がみら れ有用な脳血流評価法と思われるが、CAS前のASL とSPECTの脳血流差が大きい場合にはCAS後の両 者の脳血流差も大きくなり結果の解釈に注意を要す るものと思われる。

\section{Multi-delay ASLによるCEA周術期脳循 環動態評価}

${ }^{1}$ 東北大学病院 脳神経外科、 ${ }^{2}$ 広南病院 脳神経外 科、 ${ }^{3}$ 広南病院 放射線部

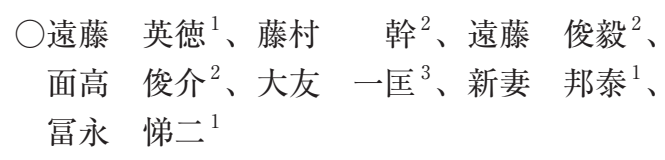

【はじめに】Arterial Spin Labeling (ASL)は、非侵 襲的に脳血流 $(\mathrm{CBF})$ を算出可能な撮影方法である。 循環遅延がある場合、単一のPost Labeling Delay (PLD)ではCBFが正確に測定できない可能性があ ることから、最近では複数のPLDを使用した撮影法 (Multi-delay ASL) が報告されている。今回、内膜 剥離術(CEA)におけるMulti-delay ASLの有用性を 検討した。

【方法】2014年以降にCEAを行った36例を対象とし た。術前ASLを全例で施行した。ASL撮影時のPLD は1525ms、2025ms、2525msの3点を使用し、それ ぞれのPLDにおけるCBF健側患側比 (Asymmetry index：AI)を求めた。また、3点におけるAIの傾き をSlope index (SI) と定義し、循環遅延の指標とし て算出した。術前と術翌日のIMP-SPECTを全例で、 アセタゾラミド負荷によるIMP-SPECTを18例で施 行し、術前脳血管反応性 (CVR) を評価した。以上 のデータを元に、ASLにおけるSIとSPECTにおけ る $\mathrm{CBF} \cdot \mathrm{CVR}$ 比較検討した。

【結果】SI と術前 $\mathrm{CBF}$ は相関係数 $-0.44(\mathrm{p}=0.0065)$ で負の相関、SI と術前 CVR は相関係数 -0.5521 $(\mathrm{p}=0.0175)$ で負の相関、SI 術後CBF増加率は相関 係数 $0.58(\mathrm{p}=0.0002)$ で正の相関を示した。ROC曲 線に基づいて $\mathrm{SI}=23.2$ を cut off值とした場合、画像 上の過灌流を診断する感度は 1 、特異度は 0.91 、陽 性予測值は 0.4 、陰性予測值は1であった。

【結語】CEA周術期において、ASLにおけるSIと SPECT所見はある程度の相関を示した。Multi-delay ASLはCEAの周術期循環動態の把握、特に過灌 流の予測に有用である可能性がある。 


\section{インドシアニングリーンの通過時間を基 にした脳外科手術中の脳血流速マッピン グ}

1 電気通信大学大学院 情報理工学研究科 機械知 能システム学専攻、 ${ }^{2}$ 江戸川病院 脳神経外科、

${ }^{3}$ 東京都済生会中央病院 脳神経外科、 ${ }^{4}$ 電気通信大 学 脳科学ライフサポート研究センター

$\bigcirc$ 蜂谷 亮太 ${ }^{1}$ 、石川 眞実 ${ }^{2}$ 、寺尾 聰 ${ }^{3}$ 、 武田 寛史 ${ }^{1}$ 、須貸 拓馬 ${ }^{1}$ 、正本 和人 ${ }^{1,4}$

【目的】本研究グループでは、血中に一過性に投与し た蛍光色素の通過時間を計測することで、脳表血 管の血流速のマッピングが可能であることをげっ 歯類を用いた動物実験で報告した(Hoshikawa et al. Microcirculation 2016)。本研究では、臨床におけ る提案法の有用性について、脳外科手術中の画像 データを用いて検討することを目的とした。

【方法】解析には、血管吻合手術前後に撮像した術 中ICG蛍光血管撮影動画を使用し、数值解析ソフト ウェアMatlabを用いて解析した。まず、呼吸心拍 によるモーションアーチファクトを低減するためフ レーム毎に位置補正を行い、各ピクセルにおける ICGの時間輝度変化を基にして血管領域を抽出した。 次に、各血管の分岐点もしくは終点ごとにセグメン ト化し、セグメント毎に血管長さと血管径を算出し た。次に、血管セグメント内の各ピクセルにおい て、ICGの立ち上がり時間を求めた。ここで、各ピ クセルにおいてICG輝度の上昇フェーズに対して最 小二乗法を用いて線形近似を行い、ピークの $50 \%$ に 到達する時間を立ち上がり時間、また得られた直線 の傾きをICGの上昇速度とそれぞれ定義した。各血 管の中心線上において立ち上がり時間をプロットし、 ユークリッド距離法で定めた中心線上での距離と立 ち上がり時間の差分から血管内最大血流速を算出し 画像化した。

【結果】脳表動脈では、吻合手術前に1.3-7.3cm/sであ り、吻合術前後の単一血管における血流速の変化を 画像化することが可能であった。一方の静脈では、 $0.2-1.5 \mathrm{~cm} / \mathrm{s}$ と吻合術前後に一過性に上昇もしくは下 降する血管が認められた。

【結語】術中ICG蛍光血管撮影動画を用いて、脳表の 単一血管内の血流速マッピングが可能であることを 確認した。

\section{虚血性脳血管障害症例における有酸素運 動に伴う脳循環応答の検討 : ${ }^{15} \mathrm{O}-\mathrm{H}_{2} \mathrm{O}$ を 用いたPET研究の知見から}

${ }^{1}$ 法政大学 スポーツ健康学部、 ${ }^{2}$ 東京医科歯科大学 脳神経外科、 ${ }^{3}$ 東京都健康長寿医療センター 神経 画像研究チーム

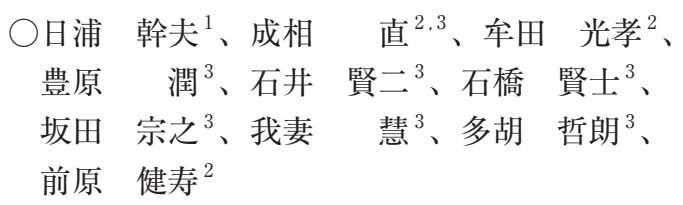

【目的】虚血性脳血管障害後のリハビリテーションに おける運動療法として有酸素運動が活用されている が、呼吸循環器応答と併せて脳循環や神経受容体の 変化を観察した研究は少ない。本研究では虚血性脳 血管障害の患者群と健常者群を対象として運動処方 時のリスクである血圧変動と神経可塑性と関連する 局所脳血流量 $(\mathrm{rCBF})$ 変化について検討した。

【方法】5名の虚血性脳血管障害の既往のある男性 (34 \pm 13 才) と 12 名の健常男性 ( $22 \pm 3$ 才)を対象とした。 中等度強度の 20 分間の仰臥位サイクリング運動を 実施しその前後でPET計測を行い、心拍数、動脈血 圧を同時に計測した。 $\mathrm{rCBF}$ は $^{15} \mathrm{O}-\mathrm{H}_{2} \mathrm{O}$ 投与後autoradiography法にてrCBFを算出した。

【結果】安静時のrCBFが低下した脳領域では虚血 部位では運動に伴う $\mathrm{rCBF}$ 変化を認めなかったが、 $\mathrm{rCBF}$ が低下していない脳領域と健常群では運動開 始時に著明な血圧上昇と小脳、脳幹、運動感覚野な どに $\mathrm{rCBF}$ 増加を認めた $(\mathrm{P}<0.05 、$ corrected $)$ 。運 動後は島皮質、視床下部に $r \mathrm{CBF}$ 減少を認めた $(\mathrm{P}$ $<0.05$ 、corrected)。安静時から運動中に収縮期 血圧 $(\mathrm{SBP})$ は $19.8 \mathrm{mmHg}$ 上昇し $\mathrm{rCBF}$ は20-25\%増 加する部位を認め、運動後SBPは安静時と比較し 9.1mmHg降下しrCBFは10-20\%減少した。

【考察】有酸素運動時の血圧変化と $\mathrm{rCBF}$ の関係性は、 安静時における脳血管調節能とは異なる機序で検討 する必要がある。運動中のrCBF増加は神経可塑性 を誘導する脳機能改善のメカニズムの一因であるが、 運動後低血圧に伴う rCBFの過度な低下のリスクな ど、脳循環の見地から運動の安全限界を今後も検討 する必要がある。 


\section{軽度認知症における認知機能低下に対す る脳血流低下と無症候性大脳白質病変の 関与}

${ }^{1}$ 東京女子医科大学 神経内科、 ${ }^{2}$ 東京女子医科大学 八千代医療センター 神経内科、 ${ }^{3}$ 東京女子医科大 学 画像診断・核医学科

$\bigcirc$ 吉澤 浩志 ${ }^{1}$ 、関 美沙 $^{1}$ 、内山由美子 ${ }^{2}$ 、
阿部光一郎 ${ }^{3}$ 、北川 一夫到 $^{1}$

【目的】アルツハイマー病において、局所脳血流の低 下は認知機能低下と関与し、また無症候性大脳白質 病変を伴うほど前頭葉機能低下がみられることが報 告されている。今回軽度認知障害を対象に各種神経 心理検査、脳血流SPECT、および頭部MRIを施行し、 認知機能低下に対する画像所見の影響について検討 した。

【方法】2013年10月～2016年 3 月にものわすれを主 訴に当科に受診した患者の中で、初診時に詳細な神 経心理検査と脳血流SPECTを施行し得た 177 例を対 象とした。神経心理検査はMMSE、FAB、WCST、 RAVLT、ROCFT、 digit span、TMT、SDMT、 Stroop、語想起課題を行った。無症候性大脳白質病 変はFazekas分類を用いて評価し、側脳室周囲病変 ないし深部皮質白質病変が grade2 以上の者を陽性 群、それ以外を陰性群とし、各種神経心理検査のス コアの比較を行った。脳血流SPECTはECDを用い、 解析にはSPM8を使用した。1年後に再評価し得た 53 例に関し、MMSEが2点以上の低下を悪化群、2 点未満を維持群として、初診時の各種検査の影響を ロジスティック回帰分析にて検討した。

【結果】無症候性大脳白質病変陽性群は陰性群に比 し、女性が多く、また高齢であった(陽性群 77.5 \pm 6.4 歳、陰性群 $74.1 \pm 8.6$ 歳)。神経心理検査では、 MMSE、FAB、記憶検査の各項目、注意機能、言 語機能には有意差はみられなかったが、TMT-A/B とSDMTにて陽性群は有意な低下がみられた。脳血 流SPECTでは、陽性群は陰性群に比し、左前頭葉 と両側頭頂葉の血流低下がみられた。1年後の認知 機能悪化に影響を与えた検査はRAVLT、ROCFT などの記憶検査の項目であり、画像検査指標は関与 しなかった。

【結論】軽度認知障害においても、無症候性大脳白質 病変を伴うほど前頭葉機能低下が示唆される。

\section{ALS患者頚髄では糖代謝と血流のuncou- plingが起きている}

${ }^{1}$ 岡山大学大学院 脳神経内科学、 ${ }^{2}$ 香川大学 脳神 経外科、 ${ }^{3}$ 香川大学 放射線科、 ${ }^{4}$ かがわ総合リハビ リテーション病院

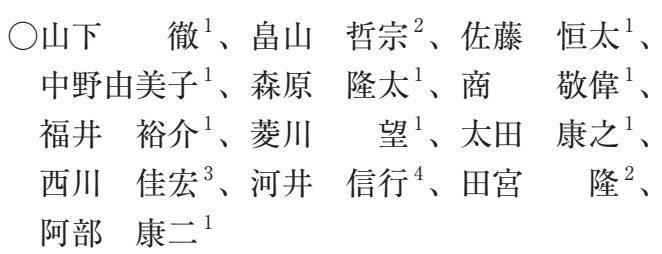

【目的】筋萎縮性側索硬化症 (ALS) は、運動ニューロ ンが選択的かつ進行性に変性・消失する原因不明の 疾患であり、人工呼吸器を用いない場合 $2 \sim 5$ 年で 死亡する致死的疾患である。近年の positron emission tomography (PET) を用いた研究から、ALS患 者の大脳皮質の糖代謝と神経密度が低下しているこ とが報告され、ALSの病態との関連も議論されてい る。

【方法】そこで今回我々は ${ }^{18} \mathrm{~F}$-2-fluoro-2-deoxy-Dglucose $\left({ }^{18} \mathrm{~F}\right.$-FDG $)$ と ${ }^{11} \mathrm{C}$-flumazenil $\left({ }^{11} \mathrm{C}\right.$-FMZ) とい う2つのPETを用いて、10名の上肢筋萎縮を呈する ALS患者と 10 名のコントロール患者の頝胸髄の糖 代謝と血流、神経密度を評価した。

【結果】 ${ }^{18}$ F-FDG PETの結果、ALS患者では、コント ロール患者と比べてC5とT1レベルの脊髄糖代謝が 有意に克進し $(* \mathrm{p}<0.05)$ 、かつ上肢機能に関連した ALS-FRS-Rスコアの低下速度と有意な相関を認め た $(\mathrm{R}=0.645 、 * \mathrm{p}=0.041) 。$ 一方、 ${ }^{11} \mathrm{C}-\mathrm{FMZ} \mathrm{PET}$ では 脊髄血流ならびに神経密度は特に変化を認めなかっ た。

【考察】以上の結果より、ALSの病態進展に脊髄糖 代謝の異常克進が関与していることが示唆された。 ALS患者脊髄では、代謝と血流の uncouplingが起 こっていると考えられ、その是正が治療標的の1つ となりうると考えられる。 


\section{急性期ラクナ梗塞穿通枝梗塞の回復過程 における脳循環代謝と神経線維密度の変 化}

${ }^{1}$ 国立循環器病研究センター 脳血管内科、 ${ }^{2}$ 国立循 環器病研究センター 画像診断医学部、 ${ }^{3}$ 国立循環 器病研究センター 脳血管リハビリテーション科

\begin{tabular}{|c|c|c|}
\hline ○安藤 & 大祐 ${ }^{1}$ 、越野 & 一博 ${ }^{2}$ 、安野 \\
\hline 佐藤 & 健朗 ${ }^{1}$ 、山本 & 明秀 $^{2}$ 、尾谷 \\
\hline 豊田 & 一則 ${ }^{1}$ 、横田 & 千晶 ${ }^{1,3}$ \\
\hline
\end{tabular}

【目的】急性期ラクナ梗塞にて手の巧緻運動障害を有 する例を対象に、リハビリテーション、日常動作に よって神経構造、脳循環代謝がどのように変化する かを検討する。

【方法】対象は、2016年4月から 2017 年 3 月の期間で 発症 7 日以内に入院したテント上ラクナ梗塞患者の うち、自立歩行可能、Brunnstrom stage V以上(巧 緻運動障害あり)で、同意取得が可能であった16例 (男 14 例、平均 63 歳、右利き15例) である。入院 後 7 日以内の入院中 (急性期) と発症 3 ヶ月後の外来 (慢性期)にて頭部MRI拡散テンソル画像 (DTI： diffusion tensor imaging) での fractional anisotrophy (FA) 值、 ${ }^{15} \mathrm{O}$-gas positron emission tomography で の脳血流量 $(\mathrm{CBF})$ 、脳酸素代謝量 $\left(\mathrm{CMRO}_{2}\right)$ 、Functional Independence Measure (FIM)、 Fugl-Meyer Assessment (FMA)、 timed up \& go test (TUG) を評価した。

【結果】左病変は 9 例であった。慢性期では急性期 に比べて FIM (125.9 vs 115.4、p=0.0011)、FMA (220.9 vs 216.4、 $\mathrm{p}=0.0215) 、 T U G$ (8.5 vs 11.2 秒、 $\mathrm{p}=0.0073$ ) が、いずれも改善した。慢性期CBFは病 変の左右に関わらず、急性期に比べて左島皮質 $(\mathrm{p}$ $<0.0001)$ 、右前部带状皮質 $(\mathrm{p}<0.0001)$ 、左中心前 回 $(\mathrm{p}<0.0001)$ 、左大脳脚 $(\mathrm{p}<0.0001)$ で増加した。 $\mathrm{CMRO}_{2}$ は有意な変化を認めなかった。慢性期FA值 は、左中心前回皮質下白質で有意に増加 $(\mathrm{p}<0.0001)$ した。

【結論】手の巧緻運動障害を有する急性期ラクナ梗塞 例では、病変の左右に関わらず、慢性期には、右手 の運動野での神経線維密度の上昇と、それに一致し た左錐体路执よび右手の運動学習、体性感覚統合に 関連する部位での脳血流上昇が見られた。

\section{Evaluation of default mode network by quantitative ${ }^{15} \mathrm{O} P E T$ : focusing on the oxygen metabolism}

${ }^{1}$ 大阪大学大学院医学系研究科 核医学、 ${ }^{2}$ 大阪大学 大学院医学系研究科 寄附講座医薬分子イメージン グ学、 ${ }^{3}$ 阪大病院 薬剤部、 ${ }^{4}$ 阪大病院 放射線部

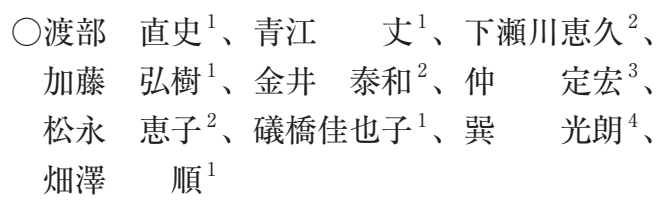

IObjectives】 In the resting state functional MRI, BOLD signal depends on the relationship between regional cerebral blood flow $(\mathrm{CBF})$ and cerebral metabolic rate of oxygen $\left(\mathrm{CMRO}_{2}\right)$, and these two factors cannot be separated. We aimed to estimate the functional connectivity by means of quantitative ${ }^{15} \mathrm{O}-\mathrm{PET}$ and compare the contribution of $\mathrm{CBF}$ and $\mathrm{CMRO}_{2}$ for default mode network (DMN) .

【Methods】 Nine healthy volunteers $(47.0 \pm 1.2$ years) were studied by means of ${ }^{15} \mathrm{O}-\mathrm{O}_{2},{ }^{15} \mathrm{O}-\mathrm{CO}$ gases and ${ }^{15} \mathrm{O}$-water PET. Quantitative $\mathrm{CBF}$ and $\mathrm{CMRO}_{2}$ images were generated by an autoradiographic method and transformed into MNI standardized brain template for anatomical normalization by SPM8. Regions of interest were placed on normalized PET images to according to the previous fMRI study. Pearson's correlation coefficients(r) were calculated for all pairs in the brain regions and correlation matrices were obtained for $\mathrm{CBF}$ and $\mathrm{CMRO}_{2}$, respectively. We defined $\mathrm{r}>0.7$ as a significant positive correlation.

【Results】 Significant positive correlations were observed in 23 pairs of brain region for $\mathrm{CBF}$ and 17 pairs for $\mathrm{CMRO}_{2}$. Among them, common networks were observed between $\mathrm{CBF}$ and $\mathrm{CMRO}_{2}(7$ pairs in the inferior temporal cortex, 4 pairs in the posterior cingulate cortex, and 7 pairs in the lateral parietal cortex) .

【Conclusions】Correlation of $\mathrm{CBF}$ revealed more brain networks compared to that of $\mathrm{CMRO}_{2}$, indicating that spontaneous activity of the local brain region influenced the change in blood flow more than that in oxygen consumption. 


\section{静脈血から動脈血放射性カウントを推定 することによるSPECT定量的脳血流量測} 定

${ }^{1}$ 仙台医療センター 脳神経外科、 ${ }^{2}$ 広南病院 脳神 経外科、 ${ }^{3}$ 東北大学 医学部 脳神経外科

\author{
$\bigcirc$ 井上 敬 ${ }^{1}$ 、藤村 幹 $^{2}$ 、江面 正幸 ${ }^{1}$ 、 \\ 上之原広司 ${ }^{1}$ 、冨永 悌二 ${ }^{3}$
}

【はじめに】脳血流を定量するために動脈血採血によ るSPECTが施行されることが多い。今回、動脈血 放射性カウントを静脈血放射性カウントから推定す る手法を検討したので報告する。

【対象・方法】対象は正常ボランティア 12 名および 脳血管性障害を有する症例 14 例とした。スペク トは島津社製HeadtomeSET080およびGE製 Infinia8Hawkeye4を用いた。核種は123IMPを用いた。 $111 \mathrm{MBq}$ を静脈投与後、連続 SPETを撮像した。撮 像 10 分後に動脈血採血、20分後にアセタゾラミド 投与、 30 分後に静脈採血、40分後に $111 \mathrm{MBq}$ 追加投 与を行った。脳血流量定量にはmicrosphere法を用 いた。静脈血の放射線カウント值および連続スペク 卜撮像時の正面像全脳放射線カウント值から重回帰 分析を用い、動脈血放射線カウント值を推定した。 さらに他装置へ応用するために、ファントム実験を 行った。

【結果】静脈血・正面像全脳放射線カウント值から推 定した值と実際の動脈血放射線カウント值との間 には正の相関を認めた $(\mathrm{r}=0.954 、 \mathrm{p}<0.0001)$ 。そこ から求めた脳血流量にも有意な正の相関を認めた $(\mathrm{r}=0.865 、 \mathrm{p}<0.0001) 。 フ ァ ン ト ム$ 実験の結果から、 装置間には正の相関を認め、これを補正することに より、他装置でも前述の重回帰式を用いる事が出来 た。

【考察】脳血流を定量するためには動脈血採血法、 脳・心同時撮像法、Xeガスの利用などが行われて いるが、それぞれ精度や装置が限定されるなどの問 題点がある。今回静脈血採血から脳血流量を定量す る手法を臨床例で応用した。得られた脳血流量およ び脳循環予備能は動脈血採血法とよく相関した。

【結語】静脈血採血SPECTの有用性が示唆された。 今後、本手法で求めた脳血流量・脳循環予備能が患 者転州予測に寄与しうるか否か検討する予定である。

\section{FP-CIT SPECTにおける半定量法の検討}

福井大学

○岡沢 秀彦、Rahman Mahmudur、

Islam Muhammad、辻川 哲也、清野 泰

【目的】現在イオフルパン(FP-CIT) SPECTの半定 量的評価は、Tossici-Bolt法をベースにしたソフト ウェアで解析されるのが一般的であり、定量性の高 い評価法とされているが、実際には脳春髄液腔 (CSF space)の影響を受けやすく、解析者により大きく変 動する場合がある。また、CSF spaceの影響を減少 させる目的で改良された最新版ソフトも、カットオ フ閾值の設定により数值が大きく変動する。こうし た定量值の変動を軽減するため、新たな解析法を考 案した。

【方法】パーキンソン症候群もしくはレービー小体型 認知症と診断された患者 176 名 (平均 $70 \pm 10$ 歳)を 対象に、[I-123] FP-CIT SPECTを行った。撮像装 置は Symbia SPECT/CT (シーメンス)で、FP-CIT 投与 3-4 時間後に撮像した。画像再構成は、減弱補 正・散乱線補正なし(NAC)、CT減弱補正・散乱 補正あり(ACSC)、CT減弱補正あり・散乱補正な し(CTAC)の3通りで、全ての患者データについて これらを作成した。Tossici-Bolt法による半定量值 $\left(\mathrm{SBR}_{\mathrm{BOLT}}\right)$ 算出はDaT Viewを用いた。新しい解析 法によるSBR值は、線条体体積相当のVOIカウント 閾値を設定し、後頭葉皮質を参照領域として、定義 通り［(線条体集積－参照領域集積）/参照領域集積］ にて計算した。

【結果】線条体部のVOIは、半自動化することで精

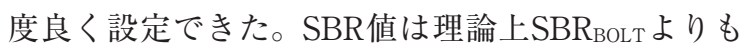
低值となるが、本検討においてもDaT Viewの結果 $\left(\mathrm{SBR}_{\mathrm{BOLT}}\right)$ と比べ有意差が認められた。新たに提唱 する方法では、異なる解析者によるSBR值の変動は 小さく、一般臨床において安定した定量值が提供可 能と考えられた。NAC、ACSC、CTACの3種類の 画像間では定量值の有意差が認められ、画像再構成 法を一定にして比較するとともに、正常域值はそれ ぞれの方法に従って設定する必要があることを確認 した。

【結語】新たに提唱した解析法によりSBR定量性の改 善が認められ、定量值の安定性が向上した。 
脳実質内、脳室内、くも膜下腔における 水のターンオーバー : Dynamic PETによ る解析と妥当性の検討

${ }^{1}$ 名古屋市立大学 医学部 脳神経外科、 ${ }^{2}$ 名古屋市 総合リハビリテーションセンター、 ${ }^{3}$ 金沢大学 医 学部 保健学科 放射線技術科学、 ${ }^{4}$ 東北大学 医学 部 高次脳機能障害学

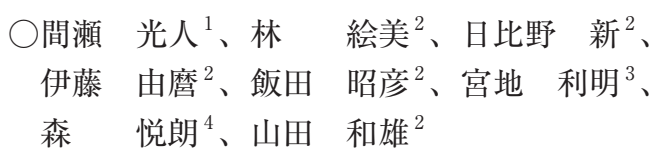

【背景及び目的】我々は既にPETを用いて脳実質・脈 絡丵から側脳室内への極めて速い水分子の移行を報告 した。今回はシルビウス裂などのくも膜下腔の検討を 併せて行うとともに、髄液移行のない核種を用いて artifactに関する検討を行った。

【方法】9 人の成人正常ボランティア $(62.0 \pm 7.6$ 才、 $\mathrm{M}$ ： $\mathrm{F}=4: 5)$ に、 $\mathrm{H}_{2}{ }^{15} \mathrm{O}$ を含む生理食塩水 $5 \mathrm{ml}$ を静脈内に bolus投与し、12.5分間にわたりdynamic PET (Siemens Biograph mCT40）dataを収集した。関心領域は内頚 動脈、上矢状洞、脈絡叢、大脳基底核、大脳皮質灰白質、 大脳白質、側脳室、シルビウス裂、橋前槽、上鼻甲介、 師板、眼球硝子体、上顎洞内エアーに置いた。減衰補 正を行った相対的放射線活性 (relative radio activity： RRA)の経時的変化を比較した。

【結果】皮質灰白質、白質のRRAピークは内頚動脈の ピークから 22.5 秒、197.5秒であった。いずれのRRA もそのpeak後は徐々に低下した。これに対し側脳室、 橋前槽およびシルビウス裂のRRAは測定終了まで増 加を続け、側脳室では 12 分後に脳全体 (灰白質、白質、 基底核）RRAの約 $38.0 \%$ に達した。側脳室と比較し橋 前槽のRRAはやや高く、シルビウス裂のRRAはやや 低かった。上鼻甲介のRRAは立ち上がりが遅れるが、 80秒以降は側頭室のRRAとほぼ同一値となった。䯣 液移行のない核種([18F］FDG、[18F］FDOPA)では 脳室、シルビウス裂のRRAの変化パターンは脳全体 と parallelで、部分容積効果によるartifactと考えられた。 【考察および結論】動脈内から脳実質への水の extractionはsingle passで85-90\%とされる。水は灰白質 から白質へ移動し、脳室内のみならず、脳槽やくも膜 下胿にも速やかに移行することが再現性をもって示さ れた。髄液に移行しない核種の䯣液腔RRAは脳全体 と同様の減衰パターンを示したのに対し、水分子の䯣 液沿への拡散は増加パターンを示したことから、本研 究の妥当性(水分子の移動を捉えている)が示された。 
一般演題 ポスター発表抄録 



\section{わが国におけるtPA治療/脳血栓回収術の 現状とSCU稼働状況 一第1回NDBオー プンデータを用いた検討一}

東京歯科大学市川総合病院脳神経外科

○菅 貞郎、吉田 啓祐、井上 賢、 片山 正輝

【目的】近年、医療にかかわるビッグデータの公開が 進んでいる。今回一般公開されたレセプト情報を 用いた悉皆性の高いNational Database (NDB)を用 いて、平成 26 年度におけるわが国の超急性期脳梗 塞に対するtPA治療/脳血栓回収術の現状とStroke Care Unit (SCU) 稼働状況との関連を明らかにする。 【方法】厚生労働省のホームページより「第1回NDB オープンデータ」にアクセスし、平成 26 年度の超急 性期脳卒中加算 $(\mathrm{tPA})$ 件数、経皮的脳血栓回収術 (EVT) 件数の年齢分布を検討した。また、EVT件 数とSCU加算件数の都道府県別分布デー夕を用いて、 その相関を検討した。

【結果】1. tPA件数は7,783件で、男性が $60 \%$ 。年齢 ピークは男性が70歳から 79 歳で $36 \%$ 、女性は 80 歳 から 89 歳で40\%。90歳以上は男性 3\%、女性 14\%。2. EVT件数は 2,860 件で、男性が $57 \%$ 。年齢ピークは 男性が70歳から 79 歳で $40 \%$ 、女性では80歳から 84 歳で $24 \%$ 。90歳以上は男性 $2 \%$ 、女性 $10 \%$ 。3. EVT は、全国平均 2.3 件/ 10 万人/年。都道府県別では、 1.3 件未満の県が 11 県、 3.3 件以上は 6 道府県で、最大 4.4 件。SCU加算件数は、全国平均 183 件/ 10 万人/年で、 最大 706 件、最小は 0 件が 17 県。またSCU加算件数 とEVT件数に相関は認められなかった。

【結語】1. tPA、EVTともに、男性は70歳代、女性 は80歳代にピークがあった。また、女性では90歳 以上でも男性に比べて高頻度で治療が行われていた。 2. EVTとSCU加算件数に相関は認められず、EVT の術後はICU/HCUで加療される場合も多いと推察 される。

\section{急性期虚血性脳卒中に対する低用量rt-PA 静注療法の臨床検討}

${ }^{1}$ 埼玉医科大学国際医療センター 神経内科、 ${ }^{2}$ 埼玉 医科大学国際医療センター 脳血管内治療科

$\begin{array}{lll}\bigcirc \text { 出口 } & \text { 一郎 } \\ & \text { 、林 } & \text { 健 }^{1} \text { 、神山 } \\ \text { 棚橋 } & \text { 紀夫 }{ }^{2} \text { 、 } \\ \text { 高尾 } & \text { 昌樹 }\end{array}$

【目的】 2005 年 10 月より本邦で発症 3 時間以内の急性 期虚血性脳卒中 (AIS) に対するrt-PA静注療法が承 認された。その後治療可能時間も 4.5 時間へ延長さ れた。しかしながらrt-PA施行患者において 3 時間 以内 $(3 \mathrm{~h})$ の治療群と 3-4.5 時間 (3-4.5h) の治療群との 有効性や安全性を比較した本邦での報告は少ない。 【方法】2007年 4 月から 2017 年 3 月の間にAISに対し てrt-PA治療を行った323例を対象に、3h拈よび 3-4.5hにrt-PA治療を行った症例について背景、転帰 (3か月後のmRS) および症候性頭蓋内出血 $(\mathrm{sICH})$ に 関して後ろ向きに比較検討した。

【成績】323例のうち3h群は219例、3-4.5h群での投与 は104例であった。そのうちrt-PA単独治療は3h群 154 例、3-4.5h群69例であった。平均投与時間(分) は、3h群、3-4.5h群でそれぞれ、148、225であっ た。3h群と3-4.5h群において、 sICH (3.9\%vs4.3\%： $\mathrm{P}=1.00) 、 \mathrm{mRS} 0-1(38.3 \% \mathrm{vs} 40.6 \%: \mathrm{P}=0.76)$ とも有 意差は認めなかった。脳血管内治療併用では、3h 群65例、3-4.5h群 35例であった。発症からrt-PA投 与、発症から穿刺までは3h群で早かったが、発症か ら再開通までの時間(分)に差はなかった(144vs266、 213vs262： $\mathrm{P}<0.001 、 297 \mathrm{vs} 319$ : $\mathrm{p}=0.079)$ 。TICI2b 以上の再開通は、3h 群、3-4.5h群で差はなかった (70.8\%vs77.1\% : p=0.638)。3h 群と 3-4.5h 群にお いて $\mathrm{sICH}(1.5 \% \mathrm{vs} 0 \%: \mathrm{P}=1.00) 、 \mathrm{mRS} 0-1(30.8 \%$ vs $31.4 \% ： \mathrm{P}=1.00$ ) とも有意差は認めなかった。

【結論】発症 $3 \mathrm{~h}$ と $3-4.5 \mathrm{~h}$ のt-PA治療は、単独または 血管内治療併用とも安全性抢よび有效性に差はな かった。 


\section{脳小血管病を有する心原性脳塞栓症患者 におけるrt-PA静注療法後の機能回復につ いての検討}

${ }^{1}$ 東京歯科大学 市川総合病院 神経内科、 ${ }^{2}$ 東京歯 科大学 市川総合病院 脳神経外科

\section{○小泉 健三 ${ }^{1}$ 、井上 賢 ${ }^{2} 、$ 片山 正輝 $^{2} 、$ 岡田 聡 ${ }^{1}$ 、村松 和浩 ${ }^{1}$ 、菅 貞郎 ${ }^{2}$}

【背景】脳小血管病 (Cerebral Small Vessel Disease ; SVD) は脳主幹動脈から分岐した細動脈、毛細血 管の微小循環や血液脳関門の障害を背景とし、脳 梗塞再発リスク、歩行障害などと関連する。近年 $r t P A$ 静注療法無効例に血管内治療を併用する有効 性 (NEJM. $2015 ； 372 ： 11-20)$ が報告されているが、 SVDを有する超急性期脳梗塞症例での機能回復へ の影響についての検討は少ない。

【目的】今回、前方循環系の超急性期脳梗塞患者に対 するrt-PA静注療法後の機能回復における、SVDの 影響について考察した。

【方法】2014年1月～2017年6月までの期間に当院で 加療された超急性期脳梗塞患者の内、発症前modified Rankin Scale (mRS) 0-1点、来院時NIHSS 5 22 点、中大脳動脈領域の心原性脳塞栓症の診断で rt-PA静注療法ないしrt-PA静注療法 + 血管内治療 が行われた症例を抽出し、発症当日に実施した頭部 MRIのtotal SVD score (Neurology 2014; $83: 1228$ 1234)が1点以下のA群、 $2 \sim 4$ 点のB群に分類し、退 院時mRS、出血性梗塞の有無について比較検討した。 【結果】 $\mathrm{A}$ 群 $(\mathrm{n}=7$; 男性 3 、女性 4 、発症前 $\mathrm{mRS} 0=6$ 例、 $\mathrm{mRS} 1=1$ 例 $) 、$ 平均年齢 $75 \pm 13$ 歳、Total SVD score 1 点が 6 例、 0 点 1 例、来院時 NIHSS $=13 \pm 6.7$ 、 Onset to Needle time $188 \pm 51$ 分、B群 $(\mathrm{n}=6$; 男性 4、女性 2 、発症前 $\mathrm{mRS}=$ 全例 0$)$ では、平均年齢78 \pm 6 歳、Total SVD score 2 点 4 例、 3 点 1 例、 4 点 1 例、来院時NIHSS $=14 \pm 5.1$ 、 Onset to Needle time $176 \pm 42$ 分であった。退院時mRSはA群で 0-3が5例 (71\%)、4-5が2例 (29\%)、B群では 0-3が2例 (33\%)、 $4-5$ が4例 (67\%)。閉塞血管の再開通率はA群で4例 (57\%)、B群で3例 (50\%)、rtPA静注 24 時間後の頭 部CT上出血性梗塞は、A群では2例 (28\%) で脳室を 圧迫する出血がみられ、B群では2例(33\%)に非圧 迫性の出血が生じた。

【結語】SVDは超急性期脳梗塞治療後の機能回復に 影響を及ぼす可能性が示唆される。

\section{血管内血栓回収療法適応決定に際しての Penumbral imagingの重要性に関する考 察}

${ }^{1}$ 慶應義塾大学 医学部 脳神経外科、 ${ }^{2}$ 脳血管研究 所 美原記念病院 脳神経外科、 ${ }^{3}$ 脳血管研究所 美 原記念病院 神経内科

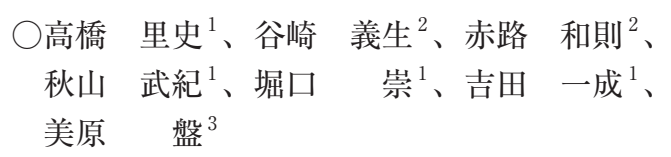

【背景】2015年に改訂されたAHAガイドラインで発 症 6 時間以内のIC及びM1 閉塞に対する血栓回収療 法が推奨された。今後発症から6時間以上経過した 症例や発症時間不明例、M2 閉塞、及び後方循環閉 塞に対する血栓回収療法の有効性の評価が待たれる。 【症例】1. 発症時間不明の 40 代 M1 閉塞の患者 2 名 に対しCT灌流画像の結果を根拠に血栓回収を施 行、2例とも TICI3の再開通を得て麻瘏は改善した。 2. 50 代、 70 代の M2閉塞の患者に対 LCT 灌流画像 の結果を根拠に血栓回収を施行、それぞれTICI2A、 TICI2Bの再開通を得た。術前にPenumbraと考えて いた領域が救済された1例でそれぞれ失語が改善し た。3. CT灌流画像のデータが得られない状況下で 50 代䅡部IC閉塞、 50 代M 2 閉塞、 70 代 M1 閉塞患者 に血行再建を行い全例TICI3の再開通と症状の改善 を認めた。3例中 2 例では術中に虚血領域がcoreで はなくpenumbraであることを示唆する側副血行を 確認できたが残る1例では確認できないままの血栓 回収施行となった。上記の症例の中で手技に伴う出 血等の合併症を認めた症例はなかった。

【考察】CT灌流画像を用いたPenumbral imagingを 元に血栓回収の適応を決めることで、血栓回収が有 効な症例を高い確率で選別することが可能と考え る。脳血管撮影による側副血行評価で代用できるこ ともあるが、側副血行を全て調べるために 6 vessel studyを行うことには時間的な制約があり、今後血 栓回収の適応拡大に際してPenumbral imagingは必 須と考えられた。 


\section{虚血ペナンブラの救出と臨床症状改善の 関連}

${ }^{1}$ 杏林大学 医学部 脳卒中医学、 ${ }^{2}$ Department of Neurology, University of Newcastle, NSW, Australia

○河野 浩之 ${ }^{1} 、$ Bivard Andrew ${ }^{2}$ 、 Parsons Mark ${ }^{2}$ 、Christopher Levi ${ }^{2}$ 、 平野 照之 ${ }^{1}$

【背景と目的】急性期脳梗塞診療におけるCT灌流画 像(CT perfusion、CTP)は、虚血コアや虚血ペナン ブラなどの脳組織の状態を可視化することができる。 本研究では、急性期脳梗塞に対する血栓溶解療法に よる脳組織救済が臨床症状と関連することを明らか にする。

【方法】急性期脳梗塞に対する血栓溶解療法前にCTP を実施する国際多施設共同前向き観察登録研究の データを用いた。治療前のCTPと 24 時間後のMRI を用いて、治療前虚血コア $(\mathrm{CBF}<30 \%$ かつ delay time $>3$ 秒)、治療前虚血ペナンブラ (delay time > 3 秒、 $\mathrm{CBF}>30 \%)$ 、救済ペナンブラ $(=$ 治療前ペナ ンブラー(最終梗塞巣一治療前虚血コア $)$ )を解析し た。脳梗塞重症度は治療前と 24 時間後のNIHSS ス コアを用いた。

【結果】発症から6 時間以内に血栓溶解療法を行った 772 例 (年齢73歳、男性 414 例) を解析した。治療前 NIHSSが1点増加する毎に、虚血コアは $2.0 \mathrm{ml}$ 増加 (95\% CI、1.5 - 2.5、p < 0.001) し、虚血ペナンブ ラは4.6ml増加 $(95 \% \mathrm{CI} 、 4.0-5.2 、 \mathrm{p}<0.001)$ した。 虚血ペナンブラを $4.0 \mathrm{ml}(95 \% \mathrm{CI} 、 3.3-4.7 、 \mathrm{p}<$ 0.001) 救済することは、NIHSSの1点改善に相当した。 【結論】虚血ペナンブラを多く救出するほど臨床症状 が改善する。

\section{血栓回収療法後のLuxury Perfusionによ る再灌流障害について}

${ }^{1}$ 長崎大学病院脳神経外科、 ${ }^{2}$ 長崎大学病院脳神経 内科、 ${ }^{3}$ 長崎大学病院放射線科

○定方 英作 ${ }^{1}$ 、堀江 信貴 ${ }^{1}$ 、諸藤 陽一 ${ }^{1}$ 、 立石 洋平 ${ }^{2}$ 、出雲 剛 ${ }^{1}$ 、森川 実 ${ }^{3}$ 、 辻野 彰 ${ }^{2}$ 、松尾 孝之 ${ }^{1}$

【背景と目的】急性期脳梗塞において血管内治療の有 用性は示されている。Arterial Spin Labeling (ASL) は非侵襲的に脳血流の評価を行うことでき、当院で もとりいれている。急性期脳梗塞に対して血管内治 療をおこなった患者の術後のASL高信号に着目し、 その臨床的意義について検討を行った。

【方法】2009年 1 月より 2016 年 2 月の間に当院で急性 期脳梗患者に対して血管内治療を行った患者は 118 名であった。そのうち治療前後でMRIを施行しえた 81名を対象とした。

【結果】平均年齢 74.3 歳、入院時にNIHSSの中央值は 16点であった。25例 (30\%) で術後MIRにてASL高 信号を認めた。TICI 0が1例、TICI 1が1例、TICI 2aが5例、TICI 2bが9例、TICI 3が10例であった。 ASL高信号となった群のうち、18例 (72\%)で梗塞 巣に微小出血または出血を認めた。

【考察】術後のASL高信号となる原因としてはvasopalarysisによるluxury perfusionが考えられる。ま たこのluxury perfusionにより微小出血または出血 が引き起こされると考えられる。再開通療法におい て術後のASL高信号は出血のリスクがあるため厳重 な管理が必要と考えられる。 


\section{機械的血栓回収療法によって得られた血 栓の病理学的検討}

${ }^{1}$ 日本大学 医学部 脳神経外科、 ${ }^{2}$ 東京曳舟病院 脳 神経外科

$\begin{array}{rrr}\bigcirc \text { 須磨 } & \text { 健 }^{1} \text { 、梶本 } & \text { 隆太 }{ }^{1} 、 \text { 五十嵐崇浩 } \\ \text { 沒辺 } & \text { 充 }^{1} \text { 、渋谷 } & \text { 肇 }^{1,2} \text { 、平山 光康 } \\ \text { 吉野 } & \text { 篤緒 }\end{array}$

【目的】急性期脳梗塞に対する機械的血栓回収療法に おいて近年、デバイスの進歩によって症状改善の ために有効な再開通所見とされるThrombolysis in cerebral infarction (TICI) grade $2 \mathrm{~B} \sim 3$ の症例が増 加している。しかし、血栓回収療法を施行した病変 おける遅発性の狭窄病変の発生が報告され血管壁へ の侵襲性が問題とされる。今回、血栓回収療法で得 られた血栓について、病理学的に検討した。

【対象】2015年 1 月より急性期脳梗塞に対して機械的 血栓回収療法を施行した20例のうち病理学的検討 が可能であった3例を対象とした。

【症例 1】82歳女性、心房細動の既往はなく、心蔵 ペースメーカーが植え込まれていた。来院時CTの ASPECT 7 点で脳血管撮影上、中大脳動脈 M2 部で 閉塞しており tPA療法を行った後にステントリト リーバー (Trevo XP 3mm)を用いて1passで血栓回 収した。病理学的には赤血球が主体の血栓で血管内 膜などは認めず、TICI grade 3の再開通が得られた。 【症例2】79歳女性、既往に心房細動はなし。中大脳 動脈 $\mathrm{M} 2$ 部で閉塞しており tPA療法後にステントリ トリーバー (Trevo XP 3mm)を用いて1passで血栓 回収した。病理学的には白血球やフィブリン成分 の割合が多かったが、血管内膜などは認めずTICI grade $2 \mathrm{~A}$ の再開通となった。

【症例3】73歳男性、心房細動の既往あり。頸部内頸 動脈の閉塞例であった。tPA療法が先行して行われ、 Penumbra sysytemとステントリトリーバー (Trevo XP $6 \mathrm{~mm}$ ) で1passで回収した。病理学的には白血球、 フィブリン、赤血球からなる血栓であったが血管内 膜などは認めずTICI grade 2Bの再開通となった。

【結論】近年のステントリトリーバーによる血栓回収 療法は血管壁への剥離損傷が少ない治療法と考えら れた。

\section{脳虚血症状の出現から2年以内の経過で 両側内頚動眽閉塞に至った甲状腺機能六 進症合併類もやもや病の一例}

自治医科大学 内科学講座 神経内科学部門

$\begin{array}{rrrr}\text { ○鈴木 } & \text { 雅之、松薗 } & \text { 構佑、金 } & \text { 蓮姫、 } \\ \text { 小澤 } & \text { 忠嗣、益子 } & \text { 貴史、嶋崎 } & \text { 晴雄、 } \\ \text { 小出 } & \text { 玲爾、松浦 } & \text { 徹、藤本 } & \text { 茂 }\end{array}$

【背景】もやもや病と類似した脳血管病変を示す疾患 群に基礎疾患を合併している場合は、類もやもや病 と定義されるが、その病態生理については不明な点 が多い。今回我々は、甲状腺機能立進症合併の類も やもや病の若年女性で、脳虚血症状出現から 2 年以 内に両側の内䅡動脈閉塞に至った症例を経験したの で報告する。

【症例】25歳女性。X-7年から動悸、息切れを認める ようになった。X-2年、頭痛と発熱に加え、突然の 歩行困難と構音障害を認め、近医脳神経外科を受診 した。頭部MRAで両側内澒動脈終末部の軽度の狭 窄を認めたため、当科を紹介受診した。当科初診時 に甲状腺機能の立進 $(\mathrm{TSH}<0.02 \mu \mathrm{IU} / \mathrm{ml}$ 、free T3 $13.35 \mathrm{pg} / \mathrm{ml}$ 、 free T4 $4.56 \mathrm{ng} / \mathrm{ml}$ ) を認め、甲状腺機 能立進症合併の類もやもや病と診断した。チアマ ゾール内服により甲状腺機能立進に伴う症状は消失 した。保存的に経過観察していたが、X-1年に一過 性の構音障害、X年に左上肢の一過性の脱力が出現 し、当科に入院した。頭部MRAでは両側内頝動脈 遠位部の血流は途絶しており、脳血流SPECTでは 前方循環系の血管反応性の著明な低下を認めた。

【考察】甲状腺機能立進症合併の類もやもや病では、 もやもや病と比較して血管病変の進行が速いと報告 されており、本症例でも 2 年以内の経過で両側内頚 動脈の血流途絶に至った。本疾患の特徴について文 献を含めて報告する。 


\section{頭蓋外内バイパス術後急性期に低灌流に もかかわらす症候性血管原性浮腫を生じ た成人もやもや病の1例}

\author{
${ }^{1}$ 東北大学医学系研究科神経外科学分野、 ${ }^{2}$ 広南病 \\ 院脳神経外科、 ${ }^{3}$ 東北大学医学系研究科放射線診断 \\ 学分野
}

$\bigcirc$ 田代 亮介 ${ }^{1}$ 、藤村 幹 ${ }^{2} 、$ 麦倉 俊司 ${ }^{3}$ 、 新妻 邦泰 $^{1}$ 、遠藤 英德 $^{1}$ 、冨永 悌二 $^{1}$

【はじめに】浅側頭動脈・中大脳動脈 (STA-MCA) 吻 合術は、成人もやもや病に対する有効な治療法であ るが、周術期合併症として脳虚血と過灌流症候群が 知られている。特に過灌流は血管原性浮腫に起因す る局所神経脱落症状や遅発性頭蓋内出血の原因とし て重要である。今回バイパス灌流域が低灌流であり ながら症候性血管原性浮腫を呈した1例を経験した ので報告する。

【症例】31歳女性で特記すべき既往歴なし。両側前 頭葉、頭頂葉の多発性梗塞による失語と右不全麻瘏 にて発症。脳血管撮影にて鈴木分類で右第 2 期、左 第3期のもやもや病と診断。リハビリを経て mRS 2 で手術施行目的に当院紹介。初めに脳循環不全が高 度である左側のSTA-MCA吻合術を脳梗塞発症 3 ケ 月後に施行した。術直後に新たな神経脱落症状なし。 術後 8 時間に右上肢脱力と構音障害を生じ、次いで 右顔面痓攣を呈LCT、MRIを施行。MRAにて左浅 側頭動脈・中大脳動脈バイパスは明瞭に描出された が、バイパス灌流域である左前頭葉皮質にMRI T2 強調像で高信号を示す病変を認めた。同病変は拡散 強調像低信号でADC上昇を伴い血管原性浮腫が示 唆された。術翌日123I-IMP SPECTでは左前頭葉全 体が低灌流で過灌流現象は認めなかった。ミノサ イクリンとエダラボンによる脳保護と抗癲痌薬によ る管理を行い症状は約 10 日間で術前レベルまで改 善し、新たな梗塞や出血転化なく経過。1か月後の MRIにて血管原性浮腫の完全消失を確認し右側血行 再建術を合併症なく行った。

【考察】成人もやもや病に対するSTA-MCA吻合術後 においては低灌流にもかかわらず血管原性浮腫を呈 しうる。その機序は不明だが、内弾性板のwaving、 中膜菲薄化といった頭蓋内血管の病理組織学的脆弱 性に加えて血液脳関門に破累的に働く matrix metalloproteinase-9などの発現上昇の関与も推測された。

\section{虚血側におけるMRI ASL hyperperfu- sion pattern〜慢性期モヤモヤ病の4症 例}

山形大学 医学部 脳神経外科

\author{
○板垣 寛、小久保安昭、川並香菜子、 \\ 佐藤 慎治、山田 裕樹、佐藤 慎哉、 \\ 園田 順彦
}

虚血性脳疾患におけるMRI ASLは症例毎のATT (Arterial Transit Time)の違いが大きく、PLD毎に 得られる值が大きく異なることが知られている。こ れまで我々はASLをmultiphase PLDで撮影し、 ${ }^{15} \mathrm{O}$ PETと比較を行い、short PLDが脳灌流圧 (CBF/ $\mathrm{CBV})$ を反映している可能性があることを明らかに した。しかし、その中でCBF/CBVの低下があるに も関わらず、short PLDでhyperperfusion pattern を呈した症例が存在しており、その特徵を検討し た。症例 $1: 51$ 歳の女性。右側の虚血症状で発症し た両側 3 期のもやもや病。 ${ }^{15} \mathrm{OPET} ゙$ は、右側は左 側と比較してCBF 3\%低下、CBF/CBV 13\%低下、 CBV $11 \%$ 上昇であった。ASLではPLD1000 msec $21 \%$ 上昇、PLD $1500 \mathrm{msec} 42 \%$ 上昇、PLD $2500 \mathrm{msec}$ $72 \%$ 上昇していた。症例 $2: 11$ 歳の女児。右側の虚 血症状で発症した右側 3 期、左側 2 期のもやもや病。 ${ }^{15} \mathrm{O}$ PETでは、右側は左側と比較してCBF 10\%低 下、CBF/CBV 24\%低下、CBV 15\%上昇であった。 ASL ではPLD1000msec $11 \%$ 上昇、PLD1500msec $11 \%$ 上昇、PLD $2500 \mathrm{msec} 24 \%$ 上昇していた。症例 $3: 49$ 歳 女性。左側の虚血症状で発症した右側 3 期、左側 2 期のもやもや病。 ${ }^{15} \mathrm{O}$ PETでは、左側は 右側と比較してCBF 4\%低下、CBF/CBV 13\% 低 下、CBV 16\%上昇であった。ASLではPLD1000msec $7 \%$ 上昇、PLD $1500 \mathrm{msec} 5 \%$ 上昇、PLD $2500 \mathrm{~m}$ sec $13 \%$ 低下していた。症例 $4: 10$ 歳の女児。両 下肢の虚血症状で発症した両側 3 期のもやもや病。 ${ }^{15} \mathrm{O}$ PETでは、右側は左側と比較してCBF 4\% 低 下、CBF/CBV 23\%低下、CBV 21\%上昇していた。 ASL では PLD1000msec 7\% 低下、PLD1500msec $19 \%$ 上昇、PLD2500msec 5\%低下していた。以上 4 症例は ${ }^{15} \mathrm{O}-\mathrm{PET}$ において虚血側で非虚血側と比較し てCBVの上昇を認めた。また、ASLではshort PLD (特にPLD1500msec)でASL-CBFの上昇を認めた。 short PLD (PLD1000、1500msec) での hyperperfusion patternの所見はCBV上昇を反映している可能 性が示唆された。 


\section{もやもや病におけるarterial spin label- ing法の有用性と問題点}

${ }^{1}$ 由利組合総合病院 脳神経外科、 ${ }^{2}$ 秋田大学医学部 附属病院 脳神経外科、 ${ }^{3}$ 大曲厚生医療センター 脳 神経外科

$\bigcirc$ 高橋 佑介 $^{1}$ 、大久保敦也 ${ }^{2}$ 、國分 康平 $^{2}$ 、 清水 宏明 ${ }^{2}$ 、柳澤 俊晴 $^{3}$

【背景】 Arterial spin labeling (ASL) は外因性のト レーサーを必要とせず、非侵襲的、繰り返して脳血 流量を測定可能な技術である。もやもや病では手術 の適応、術後の過灌流症候群の予測に脳血流評価が 重要であるが、周術期の脳血流評価にASLを用いた 報告は少ない。今回、我々はもやもや病周術期にお けるASLの有用性を検討した。

【方法】2014年 4 月から 2016 年 9 月までに手術を行っ たもやもや病 15 症例中、術前後にIMP-SPECT お よびASLを行った10例を対象とした。ASLは 1.5 T MRI、 pulsed continuous ASL 法、 post labeling delay (PLD) は全例で1.5秒、5例で2.5秒を撮像した。 IMP-SPECT、ASL は Three-dimensional stereotaxic region of interest templateを用いて患側/健側比 を計測した。術前後のIMP-SPECTとASLの相関を Pearsonの相関分析を用いて検定した。

【結果】術前ASLではPLD 1.5秒で10例中 7例に脳表 に生じる arterial transit artifact (ATA)がみられた。 術前ASLとSPECTに有意な相関はみられなかった $(\mathrm{p}=0.3328) 。 \mathrm{ASL}$ 患側/健側比は、50\%の症例で SPECTと同様に低下していた (matched group)が、 $50 \%$ 症例ではSPECTでの血流低下部がASLで は上昇していた(unmatched group)。Unmatched groupのATAはmatched groupに比べて有意に強く みられた $(\mathrm{p}=0.0168)$ 。また、unmatched groupでは matched groupに比べてivy signが有意に強くみら れ $(\mathrm{p}=0.0442) 、 A T A と \mathrm{ivy}$ signの局在はよく一致し ていた。術後検査ではSPECTとASLは有意な相関 はみられなかったが、術前に比べると相関は強い傾 向 $(p=0.0615)$ であった。術後ASLではATAが軽減 していた $(\mathrm{p}=0.0495) 。$

【結論】周術期のASLはivy signが明らかで無い場合 には有用であると考えられた。Ivy signが発達して いる症例ではASLはartifactのためCBFを正確に評 価できないと考えられる。術後のASLはATAが軽 減するためSPECTとの相関が強まると考えられた。

\section{もやもや病のT 2 *強調画像における皮質/ 皮質下血管低信号の検討}

${ }^{1}$ 带広厚生病院脳神経外科、 ${ }^{2}$ 札幌医科大学医学部 脳神経外科

$\bigcirc$ 能代 将平 ${ }^{1}$ 、金 相年 ${ }^{1}$ 、津田 宏重 ${ }^{1}$ 、 三上 毅 ${ }^{2}$ 、大瀧 雅文 ${ }^{1}$

【目的】急性期脳梗塞患者の T $2 *$ 強調画像で、脳虚血 が生じている範囲に低信号域が描出されるとする報 告がある。これは酸素摂取利用立進に伴う還元型へ モグロビンの上昇が原因のBOLD効果で生じるとさ れている。今回、我々は慢性脳虚血を病態とするも やもや病患者のT $2 *$ 強調画像で認めた皮質/皮質下 血管低信号の臨床的意義を検討した。

【方法】2012年から2015年に札幌医科大学病院でも やもや病と診断された 17 例 34 側 (男性 3 例、女性 14 例、平均年齢 37.0 歳) と、対照群として非虚血性疾 患 18 例 36 側 (男性 5 例、女性 13 例、平均年齢 30.5 歳) を対象とした。3.0Tesla MRIで撮影されたT $2 *$ 強調 画像で皮質/皮質下に描出される血管の低信号域を 動脈灌流域に分け、病態や他の画像所見と共に検討 した。

【結果】両群で皮質/皮質下血管低信号はMCA領域で はシルビウス裂-側脳室の高さに描出が多く、ACA 領域では側脳室よりも高位で多く描出されていた。 もやもや病群では非虚血性疾患群と比べ、MCA、 $\mathrm{ACA}$ 領域ともに皮質/皮質下血管低信号の描出が多 かった $(\mathrm{P}<0.001)$ 。両群とも ACA 領域に比べMCA 領域に多く描出されていた $(\mathrm{P}<0.001)$ 。もやもや 病患者ではFLAIRでのivy signとの関連は見いだせ なかったが、MRA scoreが高い症例でより皮質/皮 質下血管低信号の描出は多かった $(\mathrm{P}=0.017)$ 。また、 虚血発症例だけでなく、出血発症例や無症候性例で も皮質/皮質下血管低信号の描出は認められた。血 行再建術を行った症例では皮質/皮質下血管低信号 が減少する例が多かったが、統計学的に有意なもの ではなかった $(\mathrm{P}=0.17) 。$

【結語】もやもや病患者におけるT $2 *$ 強調画像での皮 質/皮質下血管低信号は、脳の虚血状態を示唆する 所見であるが、病態との関連に関しては更なる検討 が必要である。 


\section{もやもや病血行再建術後過灌流症候群で のIMZ SPECTの有用性}

山梨大学 脳神経外科

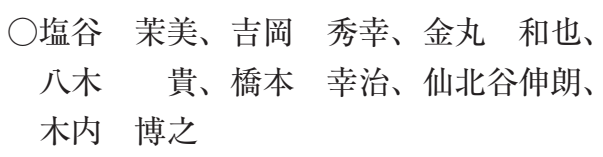

【はじめに】成人もやもや病の直接血行再建術後に は、約 4 割の症例で過灌流症候群を発症し、一過 性神経脱落症状を呈することが知られている。一 方、 ${ }^{123} \mathrm{I}$ - iomazenil (IMZ) は中枢性ベンゾジアゼ ピン受容体に結合し、本SPECTの早期像は脳血流 を、晚期像での集積低下は、皮質神経細胞の障害や 活動性の指標となりうることが報告されている。し かしながら、血行再建術後過灌流症候群における 同SPECT所見は現在まで検討されていない。今回、 もやもや病血行再建術後に過灌流症候群を呈し、同 時期に施行したIMZ SPECTで吻合部灌流域に一致 した一過性の血流増加と皮質神経細胞の活動性低下 を検出し得た一例を経験したので文献的考察を加え 報告する。

【症例】46歳の女性。左側頭葉皮質下出血にて発 症し、再出血予防目的に左浅側頭動脈中大脳動脈 (STA - MCA) 吻合術と間接血行再建術の複合手術 を施行した。術後、神経症状の出現は認めなかっ たが、翌日の ${ }^{123} \mathrm{I}$ - isopropyl-p - iodoamphetamine SPECTでは吻合血管の灌流域の左前頭葉に過灌流 所見を認めた。術後 3 日より運動性失語症を発症 し、過灌流症候群と診断した。同時期に施行した IMZ SPECTでは、吻合部灌流域は、早期像で集積 が充進し、晚期像では低下していた。約 1 ケ月の経 過で運動性失語は回復し、IMZ SPECT所見は早期 像、晚期像とも正常化した。

【考察・結語】IMZ SPECTは、頭蓋内血行再建術 後過灌流症候群での一過性の脳血流増加と皮質神経 細胞活動の低下を同時に検出することが可能であり、 本病態の診断における有用性が示唆された。

\section{外傷性くも膜下出血後高次脳機能障害患 者におけるフルマゼニルPETを用いた大 脳皮質神経障害部位の検出}

\author{
${ }^{1}$ かがわ総合リハビリテーション病院 脳神経外 \\ 科、2香川大学 医学部 脳神経外科
}

○河井 信行 ${ }^{1}$ 、畠山 哲宗 ${ }^{2}$ 、田宮 $\quad$ 隆 $^{2}$

【はじめに】外傷性くも膜下出血後に高次脳機能障害 が後遺し慢性期の頭部MRIで異常が検出できなかっ たが、中枢性ベンゾジアゼピン受容体を定量的に評 価できる11C-フルマゼニル (FMZ)を用いたPET検 查にて、くも膜下出血部位に一致して大脳皮質神経 細胞障害が認められた一例を経験したので報告する。 【症例】30歳台、女性。横断歩道を渡ろうとしたとこ ろを乗用車にはねられ頭部を強打し、近医に救急搬 送された。搬送時の意識レベルはGCS12 (E3V4M6) であった。受傷 3 時間後に撮影した頭部MRI（1.5T） FLAIR画像では、左前頭葉と頭頂葉の脳溝に線状 の高信号域が認められ、外傷性くも膜下出血と診断 された。保存的に加療され、数日後の頭部MRIでは くも膜下出血はほとんど消失し、脳実質に明らかな 損傷部位は認められなかった。1か月後に自宅退院 したが、物忘れが多い、うっかりミスが目立つなど の症状が認められ、受傷から 1 年半後に当院を紹介 となった。

【PET検查】FMZ静注後60分間のダイナミック撮像 を行い、橋を referenceとするbinding potential (BP) 画像を作成した。統計学的画像解析ソフト3D-SSP を用いて正常被験者群 20 名 (平均年齢 $24.4 \pm 2.8$ 歳) と比較して有意 $(Z$ score $>2)$ に神経細胞が障害され た部位を検出した。

【結果】WAIS-IIIにて、言語性IQ78、動作性IQ82、 全検查IQ78 と全般的な認知機能の低下が認められ、 脳外傷後高次脳機能障害と診断された。T2*やSWI 画像を含めた頭部MRI（3T)では脳実質の損傷を確 認できなかったが、FMZ-PETで急性期の頭部MRI にてくも膜下出血を認めた部位にほほ一致して有意 なFMZ集積低下が認められた。

【結論】急性期の軽微な脳損傷は、短期間で消失し頭 部MRIでも早期に異常が認められなくなることがあ る。FMZ-PETは頭部MRIで異常が消えたのちにも 機能的に神経細胞障害部位を検出できる可能性があ り、外傷性脳損傷に伴う高次脳機能障害の診断や病 態解明に役立つものと考元られる。 


\section{Arterial spin labeling MRIにて継時的 に脳灌流を評価した可逆性脳血管攣縮症 候群の一例}

市立奈良病院 神経内科

殿村 修一、掛樋 善明、清水 久央、
高橋 信行

【はじめに】可逆性脳血管攣縮症候群 (Reversible Cerebral Vasoconstriction Syndrome；RCVS)におけ る脳灌流評価では、急性期において低灌流が生じる ことが報告されている。今回、RCVSと診断した患 者において継時的にArterial spin labeling (ASL)を 用いて脳灌流評価を行い、急性期に灌流上昇を認め た一例を経験したので報告する。

【症例】30歳女性。視野障害をともなう頭痛を主訴に 来院した。受診 5 日前に雷鳴様頭痛が出現、受診 2 日前より視野障害を自覚し眼科受診し、左上 4 分の 1 盲と診断され頭部MRIを実施したところ右後頭葉 内側の急性期脳梗塞、右後大脳動脈の狭窄を認め当 院に緊急入院した。他疾患の鑑別を行い、臨床経過 とMRAの所見からRCVSと診断、入院 2 日目に評価 したArterial spin labeling (ASL)では、右広大脳動 脈領域に集積克進を認め、同領域にはガドリニウム 造影MRIで脳血液関門の破綻を示唆する所見を認め た。入院後ベラパミル内服を開始し、頭痛は改善し たものの視野障害は残存、14日目に自宅退院した。 経時的なMRIの評価では灌流立進は2週間後までに 改善を認めた一方、脳血管攣縮の改善には3 月をを 要した。

【結語】RCVSにおいては、急性期に造影剂やシン チを用いた脳灌流評価は繰り返し評価することが難 しく、侵襲性の少ないASLの有用性が示唆されてい る。これまで、ASLを用い脳灌流を評価した研究で は、急性期の低灌流は報告されているものの、我々 の涉猟し得た限りでは過灌流を呈した報告は認めな かったため、その機序に関して文献的考察を行う。

\section{脳動脈瘤コイル塞栓術における術中心停 止}

岐阜大学 医学部 附属病院 脳神経外科

○植松 幸大、榎本由貴子、江頭 裕介、 大村一史、岩間亭

【背景】脳動脈瘤治療支援ステントの登場により、脳 動脈瘤血管内治療の適応が拡大した。しかし、それ に伴い血栓性合併症、デバイスのデリバリーにかか わる解剖学的問題など、ステントに特有の問題も明 らかになった。我々は脳動脈瘤コイル塞栓術におい てステント留置が直接の原因になったと考えられる 心停止の症例を経験したので文献的考察を加え報告 する。

【症例】80歳、女性。既往歴 : 高血圧、発作性心房細 動、陳旧性心筋梗塞、大動脈弁置換術後。内服歴： アピキサバン、アゼルニジピン、ビソプロロール、 アゾセミド、ピタバスタチン。現病歴：心筋梗塞入 院時の精査で左内䅡動脈一後交通動脈分岐部に未破 裂脳動脈瘤を指摘された。当初は経過観察となった が、経過中に増大傾向あり、全身麻酔下でのコイル 塞栓術を企図した。動脈瘤は最大径 $15 \mathrm{~mm}$ 、広頚で あり、動脈瘤支援ステント(Enterprise2)が必要と 考えられた。Enterprise2を動脈瘤の母血管に誘導 し、ステントを留置しようとしたところ、徐脈が出 現し、心停止に至った。心臓マッサージにより自己 心拍は再開したものの徐脈は改善せず、経静脈的一 時ペーシングを施行後に手技を継続した。コイル塞 栓終了後、麻酔からの覚醒は良好であったが、徐脈 は遷延し、術後3日までペーシングを必要とした。 【考察】開頭術においては内頝動脈周辺の頭盍内操作 で心停止が起こるとされるが、脳動脈瘤コイル塞栓 術ステント留置時の心停止は過去に報告がない。本 症例の心停止は、ステント圧着を目論むあまり、血 管壁に過剩なストレスがかかり三叉神経迷走反射が 起こったことが原因と考えられる。また、カルシウ ム拮抗薬を服用していたことも徐脈から心停止への 移行、さらには術後の徐脈遷延に影響したと考えら れる。

【結語】脳動脈瘤コイル塞栓術におけるステント留置 で心停止が起こり得る。心停止の際には速やかに手 技を中断し、蘇生措置を講じることが重要である。 


\section{上腕動脈穿刺で proximal flow control 下に頸動眽ステント留置術を行った一例}

済生会福岡総合病院 神経内科 脳血管内科

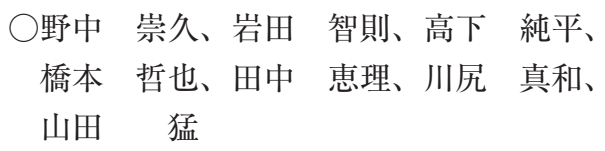

【目的】大型の不安定プラークがあり、頸動脈血行再 建術のリスク (術中塞栓症、過灌流症候群)が高いと 思われた右内頸動脈狭窄症に対し、右上腕動脈を穿 刺し、 proximal flow control下で頸動脈ステント留 置術を行った症例を報告する。

【症例】66歳男性。右内頸動脈起始部に高度狭窄NASCET 90\%の狭窄が見つかった。頸動脈エコーと 頸動脈MRAで不安定プラークが疑われた。右上腕 動脈に4 Frシースを挿入後、9 Fr Optimoに交換し た。9 Fr Optimoを右総頸動脈に留置した。Carotid Guard wire $200 \mathrm{~cm}$ を右外頸動脈に留置した。両方 のballoonを拡張した状態で9 Fr Optimoから静脈 シースに返血し、flow reversalの状態で右内頸動脈 から右総頸動脈にステントを留置した。血管造影上、 明らかな閉塞血管なく、手技は終了した。術後経過 は良好であり、周術期合併症は認めなかった。

【結論】 Proximal flow control下の頸動脈ステント 留置術は、術中合併症のリスクが高いと予測される 内頸動脈狭窄症に対して考慮されて良い方法であり、 上肢動脈アプローチも一つの選択肢である。
過換気負荷によるインドシアニングリー ン動態変化は術後過灌流を予測する

奈良県立医科大学 医学部 脳神経外科

$\begin{array}{cccc}\text { ○森崎 } & \text { 雄大、中川 } & \text { 一郎、尾本 } & \text { 幸治、 } \\ \text { 横山 } & \text { 昇平、輪島 } & \text { 大介、西村 } & \text { 文彦、 } \\ \text { 山田 } & \text { 修一、横田 } & \text { 浩、本山 } & \text { 靖、 } \\ \text { 朴 } & \text { 永銖、中瀬 } & \text { 裕之 } & \end{array}$

【目的】本邦では脳循環予備能評価として血管拡張剂 であるダイアモックスを用いるが過灌流現象の病態 は本来血管収縮不全に起因する。今回我々は澒動脈 ステント留置術 (CAS) 術前に過換気および息止め負 荷下によるICG-NIRSを行い術前脳循環予備能評価 の可能性について検討を行った。なお本研究は当院 倫理委員会の承認のもと施行された。

【方法】2014年 10 月から 2016年12月までに当院にて CASを行ない、過換気、息止め負荷テストが可能で あった66例 (男性59例、平均年齢74歳) を対象とし た。NIRO-200NX (浜松ホトニクス社)を用いて前 額部にプローべを貼布し、ICG $0.2 \mathrm{mg} / \mathrm{kg}$ を静脈内 投与して得られる時間濃度曲線から TTP (time to peak)、BFI (blood flow index) を計測し、安静時、 過換気、息止め負荷時におけるTTP、BFIの変化を 計測し、脳血流検査から得られる術前 CVR、術後 AIとの相関について検討を行なった。

【結果】術後 12 名 $(18 \%)$ で過灌流現象を認め、1例 (1.5\%)で過灌流症候群を認めた。過換気、無呼吸 負荷により $\mathrm{PaCO} 2$ の計測下に行い、有意な変動を確 認した。BFI ratio及びTTP ratioは過換気負荷、無 呼吸負荷によってそれぞれ低下、増加を示し、それ らの変化は脳血流検査から得られる術前CVR及び 術後AIと有意な相関を認め、ROC解析によるBFI ratio optimal cutoff值は0.88であった。

【結論】過換気負荷によるICG動態変化は脳循環予備 能を鋭敏に捉え、術後過灌流症候群予測モダリティ となる可能性が示唆された。 


\section{頸動眽ステント留置術における経橈骨動 眽用ガイドシースの有用性}

済生会福岡総合病院 神経内科・脳血管内科

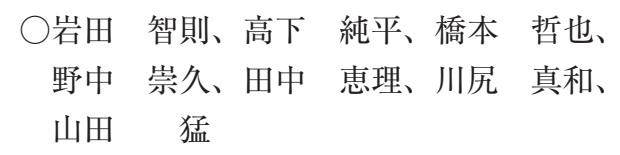

背景：頸動脈ステント留置術は経大腿動脈法で施行 されることが多い。しかし、循環器領域ではより低 侵襲な経橈骨動脈アプローチによるカテーテル治療 が主流で、橈骨動脈経由で血管内治療が選択される ことも多い。

目的：経橈骨動脈用ガイドシース $(\mathrm{GS})$ を使用し頸 動脈ステント留置術を施行した症例の手術成功率、 合併症、術後 30 日以内の死亡 ・ 心血管イベントを 明らかにすることを目的とし、retrospectiveに検討 を行った。

方法：当科では 2016 年 4 月以降、頸動脈ステント留 置術を施行する際、基本的に経橈骨動脈法でアプ ローチする方針とした。橈骨動脈閉塞があれば経上 腕動脈法でアプローチする方針とした。原則、局所 麻酔下で右橈骨動脈を穿刺し、Modified Simmons 形状である6Fr MSK-guide R (Medikit社、100cm) を経橈骨動脈用GSとして使用した。

結果 : 2016 年 4 月から 2017 年 6 月の期間に 23 例で経 橈骨動脈用GSを使用し頸動脈ステント留置術を施 行した。経橈骨上腕動脈用GSを使用した全例で手 術は成功し。1例でTIAを生じたが、退院時には神 経脱落症状は認めなかった。橈骨動脈穿刺が原因と 考えられる合併症は生じなかった。術後30日以内 の死亡や心血管イベントも生じなかった。

結論：経橈骨上脈用GSを用いた頸動脈ステント留 置術の初期成績は良好で有用な治療法であった。

\section{pure autonomic failureのDAT SPECT 所見の検討}

東京慈恵会医科大学 葛飾医療センター 神経内科

○余郷麻希子、森田 昌代、鈴木 正彦

【目的】 pure autonomic failure (PAF) は起立性低 血圧と神経因性膀胱、インポテンスなどのより広範 囲な自律神経機能障害に特徵付けられる、特発性非 遺伝性疾患である。その他の神経症候、例えばパー キンソニズムなどは存在しない。PAFはシヌクレ オパチーとされているが、剖検例ではLewy小体の 出現が報告されているため、狭義にはLewy 小体病 の一つである。長い経過のなかでパーキンソン病 (Parkinson’s disease：PD)またはレヴイ小体型認 知症 (dementia with Lewy bodies : DLB)に変化す ることもあるが、PAFがPDやDLBの prodromal期 なのかわかっていない。このため、PAFの線条体 dopamine transporter (DAT) 機能をより明らかに することを目的とした。

【方法】対象は当院を受診したPAF。全例で病歷、神 経所見、嗅覚検查、MIBG心筋シンチグラフィー、 DAT SPECT等の検查を施行し、当院の正常コント ロール (NC)、PDやDLB症例と比較検討した。

【結果】DAT VIEW解析が正常境界の症例でも、 DAT QUANT定量解析では、正常コントロールよ りも集積低下を認め、PD、DLBに比較すると保た れていた。

【考察】PDは、ドパミン神経の50\%が脱落して、運 動症状を発症する。この点からPAFで軽微な線条 体DAT機能低下があっても、運動症状を認めない 点は理解される。PAFがPD、DLBの前駆期ならば、 経時的なDAT SPECT集積低下、パーキンソニズム や認知症が表れる可能性がある。一方で、大多数の PAFが一貫して自律神経障害のみを示す点からは、 $\mathrm{PAF}$ にはパーキンソニズムや認知症への進展抑制 因子が存在すると思われる。

【結論】PAFのDAT機能障害はパーキンソニズムが なくとも存在し、経時的な観察が必要である。 


\section{進行性核上性麻舫の各臨床病型における DaT-SPECT}

${ }^{1}$ 岡山赤十字病院 神経内科、 ${ }^{2}$ 岡山赤十字病院 リ ハビリテーション科、 ${ }^{3}$ 岡山赤十字病院 放射線 科、 ${ }^{4}$ 岡山大学医歯薬学総合研究科 脳神経内科学

\begin{tabular}{|c|c|c|}
\hline 式久 & 康 ${ }^{1}$ 、鶴川 & 春佳 ${ }^{2} 、$ \\
\hline & 勝博 ${ }^{3}$ 、都能 & 和俊 ${ }^{3}$ 、 \\
\hline & 努 ${ }^{3} 、$ 林 & 英博 ${ }^{3}$ 、 \\
\hline
\end{tabular}

【目的】 Progressive supranuclear palsy (PSP : 進 行性核上性麻痺) は核上性眼球運動障害、項部ジス トニア、仮性球麻疩、認知症などが出現するパー キンソニズムをきたす神経変性疾患群として1964 年に報告され、様々な臨床病型が存在し、鑑別が 困難である。最も典型的なRichardson's syndrome (RS)、左右差がありパーキンソン病と似ているProgressive supranuclearpalsy-parkinso nism (PSP-P)、 'L-dopa無効の純粋アキネジア’で、歩行あるいは 発語のすくみ現象を主徵とするPure akinesia with gait freezing象を主徵とする Pure akinesia with gait freezing (PSP-PAGE)、小脳性運動失調が目立 つPSP with cerebellar ataxia (PSP-C)、前頭側頭 型認知症の臨床像をとるPSP with frontotemporal dementia (PSP-FTD) 等の臨床病型があり、DaTSPECTの比較検討を行った。

【方法・対象】当科外来および入院にて、PSP と診断 した患者 30 名 (男性 10 名、女性 20 名 (平均年齢 77.4 歳

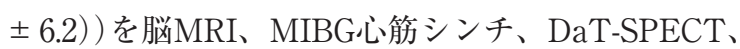
ECD脳血流シンチ、MMSE、FAB等を用い、各臨 床病型で分類し、DaT-SPECTの検討をおこなった。 【結果】臨床病型は、RS (15名)、PSP-P (4名)、PSP-C (4 名)、PSP-FTD (3名)、PSP-PAGE群(4名) に分類 された。PSPは線条体の集積が高度に低下し、尾状 核頭で低集積を示す群と、パーキンソン病と類似し た被殼後方部で低集積を示す群に大別されたが、病 型分類による特徵はなく、ADLの低下とも関連は みられなかった。

【考察】PSPは様々な病型があり、正確に診断する ためにはDaT-SPECTは不可欠である。

\section{閉塞性水頭症による認知機能障害とその 術後改善をIMZスペクトで検出し得たー 例}

山梨大学 医学部 脳神経外科

$\begin{array}{crrr}\text { ○堀内 } & \text { 諒、吉岡 } & \text { 秀幸、金丸 } & \text { 和也、 } \\ \text { 八木 } & \text { 貴、橋本 } & \text { 幸治、村山 } & \text { 裕明、 } \\ \text { 木内 } & \text { 博之 } & & \end{array}$

【はじめに】 ${ }^{123}$ I-iomazenil (IMZ) スペクトは中枢性べ ンゾジアゼピン受容体の分布を現し、その集積低下 は神経細胞の機能低下や脱落を反映するとされ、近 年脳虚血病態に打ける認知機能低下との関連も示唆 されている。しかしながら、水頭症による認知機能 障害と本スペクト所見の関連に関しては十分には検 討されていない。今回、後大脳動脈遠位部巨大血栓 化動脈瘤による閉塞性水頭症の術後に認知機能が回 復し、これに伴い両側前頭葉でのIMZスペクト所見 が改善した一例を経験したので、文献的考察を加え 報告する。

【症例】77歳の女性。56歳時に破裂左後大脳動脈遠 位部動脈瘤を保存的に治療した既往を有した。今回、 緩徐進行性の認知機能障害、歩行障害および尿失禁 にて発症した。入院時、認知機能障害は重篤で、何 とか名前が言える程度であり、長谷川式知能スケー ル (HDS-R) は0点だった。頭部MRI T2強調像では 著明な periventricular high intensityを伴う水頭症 を呈し、頭部CT血管撮影の所見を踏まえ、血栓化 巨大左後大脳動脈㽷の中脳水道圧排による閉塞性水 頭症と診断した。IMZスペクトでは、両側前頭葉で の集積低下を認めた。手術に先立って施行した左後 大脳動脈の balloon test occlusionはtolerantであっ た。手術はoccipital interhemispheric approachで 施行し、動脈瘤をトラッピング後に切除した。閉塞 性水頭症は解除され、認知機能障害は徐々に回復し、 3 ケ月後のHDS-Rは 27 点となった。IMZスペクトで の両側前頭葉の集積低下も認知機能に並行して改善 した。

【考察・結語】巨大動脈瘤に伴う閉塞性水頭症の術後 に、認知機能の正常化と共にIMZスペクト所見の改 善が認められた一例を報告した。本症例では、水頭 症による前頭葉神経細胞の機能障害と治療後の改善 をIMZスペクトが検出し得た可能性が考えられた。 


\section{頭蓋内動脈硬化症を有する認知機能低下 患者の臨床的特徵}

\author{
${ }^{1}$ 岐阜大学医学部附属病院 脳神経外科、 ${ }^{2}$ 揖斐厚生 \\ 病院 脳神経外科 \\ ○船津奈保子 ${ }^{1,2}$ 、江頭 裕 $^{1,2}$ 、澤田 重信 ${ }^{1,2}$ 、 \\ 三輪 嘉明 ${ }^{2}$ 、岩間 亨 ${ }^{1}$
}

【背景と目的】頭蓋内動脈硬化症 (ICAS) は虚血性心 血管イベントのみならず、認知機能障害のリスク因 子であることが報告されている。ICASを有する認 知機能低下患者の臨床的特徴を明らかにする。

【対象と方法】2017年1月から6月に当院で認知症検 查を受けた38例のうち、MRAでICASの有無を評価 可能であった症例を対象とした。MRAで頭蓋内主 幹動脈に $50 \%$ 以上の狭窄を認めた例をICASありと し、ICASの有無により長谷川式簡易知能評価スケー ル (HDS-R)などの認知症スクリーニング検查、MRI、 SPECTの結果を後方視的に比較検討した。

【結果】 36 例 (年齢 $81.8 \pm 5.4$ 歳、女性 16例、HDS-R 中央值21 [IQR、18-25]) を対象とした。ICASは25 例 (69\%) にみられた(内澒動脈 3 例、中大脳動脈 13 例、前代脳動脈 5 例、後大脳動脈 16 例)。ICASあり 群ではなし群に比しHDS-Rが低く(20［17.5-25］vs. 25 [20-27]、 $\mathrm{p}=0.030$ )、計算が困難で（加算、減算、 乗算、除算各5点ずつ計 20 点中、 11 [8-15.5] vs. 16 [11-17]、 $\mathrm{p}=0.047$ )、VSRADに打ける全脳萎縮領 域の割合が高かった（8.1［4.8-10.1］vs. 5.0 [4.1-6.8]、 $\mathrm{p}=0.012)$ 。部位別では、内頚動脈狭窄例では皮質陳 旧性脳梗塞が多く $(67 \%$ vs. $9 \% 、 \mathrm{p}=0.045)$ 、中大脳 動脈狭乍例ではVSRADにおける全脳萎縮領域の割 合が高く(8.9 [7.4-10.8] vs. 5.3 [4.1-7.4]、p=0.001)、 後大脳動脈狭窄例では計算が困難であった $(9$ [814.5] vs. 15 [11-17]、p=0.045)。

【結論】ICASあり群ではなし群に比べ認知機能低下 が高度で、狭窄部位によりその臨床的特徵が異なる 可能性が示唆された。

\section{NIRS検査によるうつ病と双極性障害の鑑 別への有用性}

${ }^{1}$ 昭和大学横浜市北部病院 メンタルケアセン 夕ー、 ${ }^{2}$ 昭和大学 医学部 精神医学講座、 ${ }^{3}$ 慶應義 塾大学 医学部 精神神経科学教室

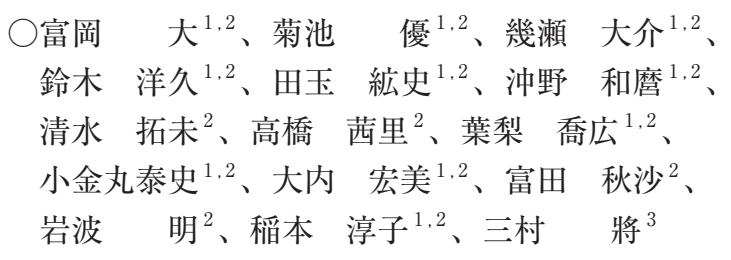

【目的】近赤外光スペクトロスコピー (Near infrared-spectroscopy：NIRS) は非侵襲的な検査で、頭 部に装着したプローブから照射され反射した近赤外 光をとらえ、毛細血管における酸化へモグロビン濃 度の変化 $(\mathrm{Oxy}-\mathrm{Hb}[\mathrm{mMmm}])$ を計測する。この脳 の循環動態の測定を利用した神経機能画像として のNIRS検査の多くの研究において、語流暢性課題 (Word fluency task：WFT) 施行中の前頭葉活動の 測定が、うつ状態の診断や治療予測評価などにおい て有用であることが示されており、精神科領域での 保険診療では「光卜ポグラフィ装置を用いたうつ症 状の鑑別診断補助のための検査」が施行されている。 今回、大うつ病性障害と双極性障害におけるうつ状 態の患者の、診断を鑑別するために、NIRS検查の 結果が役立てられる可能性を検討する。

【目的】昭和大学病院にて、うつ状態について治療 された患者について、初診時にNIRS検査を施行し、 その後の治療経過を追跡した。うつ状態は経過のな かで、躁状態等がみられ双極性障害と診断変更され ることがあり、大うつ病性障害群と診断変更となっ た双極性障害群におけるNIRS検查結果を比較した。 【成績】うつ状態を主訴とする35例の症例のうち、24 例が大うつ病性障害の診断を維持し、11例が双極 性障害へと診断が変更されていた。前頭前野におけ るOxy-Hb変化を52チャンネルで測定し、WFT施行 時に有意にOxy-Hbが上昇した部位を比較した。大 うつ病性障害群では、前頭葉両側外側領域にて有意 な上昇がみられ、双極性障害群では、前頭葉正中領 域にて有意な上昇がみられた。

【結論】うつ状態の診断補助には、Oxy-Hbの増加量 等が指標となるが、内因性精神疾患である大うつ病、 双極性障害の診断のために、NIRS検查で評価でき る前頭葉での活動部位の差が役立つ可能性が示唆さ れた。 


\section{鎖骨下動脈・腕頭動眽ステント術中の椎 骨動脈エコー所見}

山口大学医学部附属病院

○貞廣 浩和、石原 秀行、岡 史朗、 鈴木 倫保

【背景】椎骨動脈エコー検査で鎖骨下動脈盗血現象は、 まれならず観察される。鎖骨下動脈盗血症候群や上 腕・前腕の症状を有する患者には、その原因となる 鎖骨下動脈・腕頭動脈の狭窄・閉塞に対して、我々 は積極的にステント術を行っている。ステント術 中にreal-timeで患側椎骨動脈のエコーを行い、経時 的な逆行性から順行性の変化とhigh intensity transient signals (HITS)の有無を検討した。

【対象・方法】当科において鎖骨下動脈・腕頭動脈ス テント術を行った患者を対象とし、ステント術中に 患側椎骨動脈のエコー検査でduplex imagingを行っ た。検査をしやすくするため、術中は頭位を対側へ 回旋した。術中にdistal/proximal protectionは行わ なかった。前拡張、ステント留置、後拡張時にどの 様な変化があるか観察した。検者の手はプロテク ターによって保護され、術者もX線被爆には十分配 慮して行った。

【結果】6例に対して施行した。男性5名、平均年 齢 $74 \pm 6.1$ 歳、左鎖骨下動脈 4 例、右鎖骨下動脈 1 例、腕頭動脈 1 例であった。1例で前拡張後、4例で ステント留置後、1例で後拡張後に順行性となった。 HITSを認めた症例は1例のみで、これは後拡張後に 順行性になった症例であった。

【考察】鎖骨下動脈ステント時のprotectionの必要性 には議論がある。6例中5例でステント留置後には 既に順行性になっているにも関わらず、HITSは観 察されなかった。これは、頚動脈プラークの性質と は異なっている可能性が示唆される。後拡張後に順 行性になった症例では、ステント留置のみでは拡張 が不十分であり、後拡張を追加してHITSが観察さ れた。繰り返しの血管形成は塞栓のリスクがあると 考えられた。

\section{後方循環系急性期脳梗塞患者における FLAIR-hyper vesselsは閉塞血管の診断 に有用である}

日本医科大学大学院医学研究科 神経内科学分野

$\bigcirc$ 下山 隆、須田 智、西山 康裕、
大久保誠二、木村 和美

【背景】急性期脳梗塞患者におけるFLAIR-hyper vessels (FHV) は主幹脳動脈閉塞患者で高頻度に認 める。FHVに関する過去の報告は前方循環系急性 期脳梗塞患者を対象としたものが多く後方循環系に 関する検討は少ない。今回、我々は後方循環系急性 期脳梗塞患者を対象に後大脳動脈 - 椎骨動脈 - 脳 底動脈のFHVが閉塞血管の有無を評価する有用な マーカーとなり得るか検討した。

【方法】対象は 2014 年 9 月から 2016 年 6 月までに当院 に入院した発症 24 時間以内の後方循環系急性期脳 梗塞患者連続例。以下の患者は除外した1) 前方循環 系にも梗塞巣を有する、2) 入院時に頭部MRI（DWI、 FLAIR) およびMRAを施行していない。FHVの判 定は Likert scale (1; no、 2 ; little、 3 ; equivocal、 4 ; distinct、 5 ; sure)を用い、scores 4 もしくは5を FHV陽性と定義した。

【結果】121例が登録された[男性 85 例 (70.2\%)、中 央值 73 歳]。FHVは31例 $(25.6 \%)$ で認めた。FHV

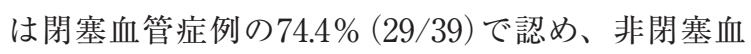

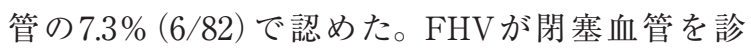
断し得る感度は $88.4 \%$ 、特異度は $82.9 \%$ であった。 FHV と閉塞血管部位との検討では、FHV陽性率は 後大脳動脈閉塞例 $80.0 \%(8 / 10)$ 、椎骨動脈閉塞例 $60.0 \%(9 / 15)$ 、脳底動脈閉塞例 85.6\% (12/14) であっ た。多変量解析で後方循環系のFHVは閉塞血管を 診断する独立因子であった(オッズ比 $33.83 ; 95 \%$ 信 頼区間 10.66-107.30、P<0.001)。後方循環系のFHV 陽性症例は3か月後の転帰不良 $(\mathrm{mRS}>3)$ と関連し ていた $(44.4 \%$ vs. $18.8 \% 、 \mathrm{P}=0.018) 。$

【結語】後方循環系急性期脳梗塞患者における FHV は閉塞血管の有無を診断する有用なマーカーである。 


\section{DOAC服用中に発症する脳内出血の臨床 的特徵}

${ }^{1}$ 国立病院機構 長崎医療センター 脳神経外科、 2 国立病院機構 長崎医療センター 薬剤部

\begin{tabular}{|c|c|}
\hline ○日宇 $\quad$ 健 ${ }^{1}$ 、大園 & 恵介 ${ }^{1}$ 、川原 \\
\hline 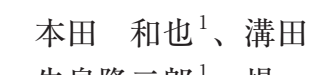 & 繁治 ${ }^{2}$ 、小野 \\
\hline
\end{tabular}

【目的】近年、DOAC服用中に発症する脳内出血の報 告は増加傾向にあるが、治療方針は一定していない。 当施設での症例を後方視的に検討し、その臨床的特 徴を明らかにすることを目的とした。

【対象】2014年-2016年に当施設で経験した急性期の 非外傷性脳内出血患者連続243例を対象とした。66 例 (全体の $27.2 \%$ ) で抗血栓薬服用中であり、抗血小 板剂単独 32 例 (13.2\%)、抗凝固薬はワルファリン 26 例 $(10.7 \%$ )、DOAC 8 例 (ダビガトラン 3 例、イ グザレルト 4例、エドキサバン 1例) (3.3\%)であっ た。ワルファリン服用群(Warfarin group：WG) と DOAC服用群 (DOAC group : DG) との臨床的背景 や治療内容およびその転帰について比較検討した。

【結果】平均年歯令は $\mathrm{WG}=75.6$ 歳、 $\mathrm{DG}=78.1$ 歳であり、 前者の $42.3 \%$ 、後者の $25 \%$ で抗血小板剂が併用され ていた。WGにおいて入院時のPT-INRが2.6を越え ていた症例は 8 例 $(30.8 \%)$ であった。入院時画像で の血腫量は $\mathrm{WG}=26.3 \mathrm{ml} 、 \mathrm{DG}=11.8 \mathrm{ml}$ でり、入院 後 24 時間以内に画像による経過観察を行った症例 の中で、WGの $39.1 \% 、 \mathrm{DG}$ の $12.5 \%$ で血腫の増大を 認めた。それぞれ $38.5 \% 、 25 \%$ で開頭術が行われた。 入院中の死亡率は $\mathrm{WG}=23.1 \%$ と高率で、半数で抗血. 小板剂が併用されており、画像による経過観察が行 われた全例で血腫の増大を認めた。一方でDGの死 亡例はなかった。退院時の転帰良好群 (mRS 0-2)の 割合はWG=11.5\%、DG=37.5\%であった。

【考察・結語】日常臨床的に遭遇するDOAC服用中の 脳内出血は稀ではないものの、血腫量および血腫増 大の割合は少なく、ワルファリン服用中の脳内出血. と比較して臨床的転帰は良好であった。

\section{非弁膜症性心房細動を有する脳梗塞・TIA 患者におけるDOAC開始時期と転帰： SAMURAI-NVAF研究}

${ }^{1}$ 国立循環器病研究センター 脳血管内科・脳神経 内科、 2 神戸市立医療センター中央市民病院 神経 内科、 ${ }^{3}$ 川崎医科大学 脳卒中科、 ${ }^{4}$ 広南病院 脳血 管内科、 ${ }^{5}$ 熊本赤十字病院 神経内科

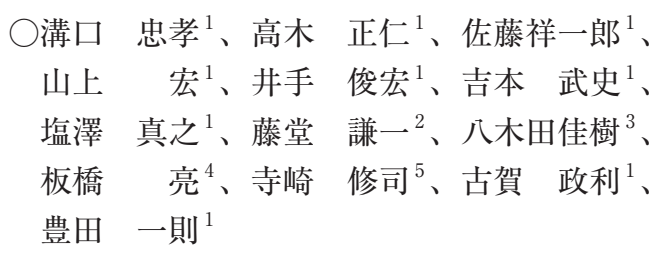

【背景】非弁膜症性心房細動 (nonvalvular atrial fibrillation：NVAF）に伴う虚血性疾患の予防にdirect oral anticoagulants (DOAC) が近年普及しているが、虚 血性脳卒中発症後のDOAC開始時期についての報告 はそしい。

【目的】虚血性脳卒中発症後のDOACを開始時期と 2 年後の転帰との関連を検討する。

【方法】2011 年9月から 2014 年 3 月の期間にSAMURAI-NVAF研究に登録されたNVAFを有する発症7 日以内の脳梗塞 - TIA患者 1192 例のうち、発症後 にDOACで経口抗凝固療法を始めた例を対象とした。 DOACの開始時期が発症後 3 日以内の早期群と発症 後 4 日以降の後期群の 2 群に分け、投与開始後 2 年 間の虚血イベント、出血イベント、死亡を比較した。 【結果】発症後にDOACで経口抗凝固療法を始めたの は499例 (42\%)であった。早期群 (223例、74 46 歳、 女性 78 例) は後期群 (276 例、75 \pm 6 歳、女性 101 例) と比べて、入院時NIHSSが低かった (中央值 3 対 5 、 $\mathrm{p}=0.001) 。 2$ 年間の虚血イベント発生率は、早期群 $10.8 \%$ 対後期群 $12.7 \%$ (HR 0.89、95\%CI 0.50-1.56)、 出血発生率は $3.6 \%$ 対 $4.0 \%(0.97 、 0.36-2.51)$ 、死亡率 は $4.5 \%$ 対 $8.7 \% 、(0.57 、 0.26-1.17)$ で、いずれも有意 差がなかった。

【考察】NVAFを有する患者に脳梗塞・TIA発症か ら3 日以内にDOACを開始しても、それ以降の開始 例と比べて長期的な虚血イベントや出血イベント、 死亡の発生率が同程度であった。 


\section{原発性アルドステロン症における微小脳 出血分布}

\author{
佐賀大学 医学部 神経内科
}

○池田 宗平、藥師寺祐介、飯田絋太郎、

田中 淳、溝口恵、原 英夫

【目的】微小脳出血 (cerebral microbleeds : CMBs) の背景病理とその分布パターンで特異的とされてい るものは、脳アミロイドアンギオパチーに扔ける脳 表限局性分布パターンのみである。今回の目的は、 二次性高血圧の代表的疾患である原発性アルドステ ロン症患者を用いたケースコントロール研究におい て高血圧性CMBs分布パターンを後ろ向きに検証す ることである。

【方法】対象(ケース群) は2006年から2016年に当院 で診断された原発性アルドステロン症患者連続 28 名のうち paramagnetic MRIを施行されていた11名 （年齢中央值 64 歳、男性 $46 \%$ ) である。コントロー ル群として同期間に当院にて頭痛の精查目的で頭部 MRIを施行されていた患者のうち、対象と性別・年 齢を調整したparamagnetic MRI撮像を有し、脳卒 中・高血圧既往のない症例 19 名 (年齢中央值 62 歳、 男性 $26 \%$ ）を抽出した。ケース・コントロール群間 で年齢、性、抗血栓薬使用・糖尿病・脂質異常症の 有無、SWI使用有無、及びCMBs分布パターン(脳 表限局型、脳深部・テント下型)を比較した。ケー 又群(従属変数) と各々のCMBs分布パターン(独立 変数) との関連について、年齢・性別と単変量解析 でp<0.20であったSWI使用を調整因子とした多変 量2 項ロジスティック回帰分析を行った。

【結果】年齢、性、抗血栓薬使用歴、糖尿病・脂質異 常症の有病率に両群間差はなかった。多変量ロジ スティック回帰分析では脳媣部・テント下型CMBs はケース群に独立して関連した $(\mathrm{OR}$ 8.05、95\% CI、 1.13-57.53)。

【結論】原発性アルドステロン症患者では、脳深部・ テント下型CMBsに特異的に関連した。本研究結果 は脳深部・テント下型CMBsが高血圧性の病理学的 変化に特徵的な画像変化であることを間接的に示し た。

\section{脳卒中後の感染は3 月月後の転帰不良と 関連する}

日本医科大学大学院医学研究科 神経内科学分野

\author{
○須田 智、青木 淳哉、下山 隆、 \\ 金丸 拓也、鈴木健太郎、坂本 悠記、 \\ 仁藤智香子、西山 康裕、三品 雅洋、 \\ 木村 和美
}

【背景と目的】脳卒中後の感染は、頻度が高い合併症 であるが、長期的な転帰との関連について、十分に は検討されていない。本研究では、脳卒中後の感染 と3 ケ月後の転帰について検討を行った。

【方法】対象は、2014年9月から2016年6月までに、 発症から 1 週間以内に脳梗塞㧍よび脳出血の診断で 当科に入院した連続 809 人 (男性 517 人、平均 72 歳) について後ろ向きに検討を行った。3 月後のmodified Rankin Scale (mRS)3-5を転帰不良群と規定し、 当科入院中に発症した脳卒中後感染と 3 ケ月後の転 帰不良㧍よび死亡との関連について多変量回帰分析 を行った。

【結果】脳卒中後感染は 169 人 $(20.9 \%) に$ に認められ、 内訳は、肺炎が 106 人 $(62.7 \%)$ 、尿路感染症が 23 人 (13.6\%)、その他の感染症が40人 (23.7\%) であった。 脳卒中後感染群は非感染群と比較して、高齢 $(\mathrm{P}<$ 0.001) で女性に多く $(\mathrm{P}<0.001)$ 、Body mass index (BMI) が低值 $(\mathrm{P}=0.0057)$ 、入院時のNIHSSが高值 $(\mathrm{P}<0.001)$ であった。3 月後の転帚不良および死 亡は、感染群で非感染群に比べて有意に高率であっ た $(41.8 \%$ vs. $4.8 \% ; \mathrm{P}<0.001 、 24.3 \%$ vs.3.9\% ; $<<$ 0.001)。更に、年齢、性別、BMI、入院時のNIHSS、 その他の様々な危険因子で調整しても、転帰不良 (odds ratio [OR]、8.68;95\% confidence interval [CI $、 4.83$ - 15.59) および死亡 (OR、 $4.98 ; 95 \%$ CI、 $2.61-9.44)$ と独立して関連していた。

【結論】脳卒中後感染は、3 月月後の転帰不良および 死亡に関連していた。 


\section{Embolic stroke of undetermined source (ESUS) 患者の再発寄与因子に関 する検討}

聖マリアンナ医科大学 神経内科

○鹿島 悟、清水 高弘、長谷川泰弘

【背景・目的】ESUSの診断に経食道心臟超音波検查 (TEE)の所見は不要とされている。ESUSの主な塞 栓源として、塞栓リスクが低い心疾患、Holter 心 電図 (24時間以上) で確認できない発作性心房細動 (Paf)、大動脈弓部複合柅腫病変、卵円孔開存 $(\mathrm{PFO})$ などが考えられるが、これらはTEEで診断可能な ものも多い。今回ESUSの診断基準を満たし、TEE を施行し得た症例の長期追跡結果をもとに、TEE 所見を含めたESUS患者の再発寄与因子を検討した。 【対象・方法】2006年 8 月から 2009年10月までに当 院に入院しTEEを施行した脳梗塞患者のうち、 ESUSの診断基準を満たした117 例 (男 88 例、平均年 齢67.9 12.3 才）を対象とした。対象患者の危険因 子(高血圧症、脂質異常症、糖尿病、喫煙)、画像所 見(頭部MRI、胸部レントゲン)、TEE所見、観察期 間中の脳梗塞再発の有無を後方視的に評価した。脳 梗塞再発の寄与因子をCox回帰分析によりハザード 比 $(\mathrm{HR})$ として求めた。

【結果】平均観察期間は3237 \pm 109.9 日で中央值は 3727 日であった。観察期間中に 17 例 (14\%) で脳梗 塞再発を認め、入院後新規に心房細動が確認された のは10例 (9\%)であった。Cox回帰分析により、大 動脈最大内膜中膜複合体厚 $(\mathrm{p}=0.045 、 H R 1.269$ 、 95\%CI 1.01-1.60) が有意な脳梗塞再発寄与因子と考 えられた。

【結語】大動脈最大内膜中膜複合体厚は、ESUS患者 の再発に関与する因子と考えられる。

\section{NIRS-IVUSを用いた脂質コアプラークの 評価}

奈良県立医科大学脳神経外科

$\begin{array}{cccc}\text { ○中川 } & \text { 一郎、尾本 } & \text { 幸治、横山 } & \text { 昇平、 } \\ \text { 森崎 } & \text { 雄大、輪島 } & \text { 大介、西村 } & \text { 文彦、 } \\ \text { 山田 } & \text { 修一、横田 浩、本山 } & \text { 靖、 } \\ \text { 朴 } & \text { 永銖、中瀬 裕之 } & \end{array}$

【目的】 NIRSは近赤外線スペクトロスコピー法(分 光法)による画像診断技術であり、脂質成分が他の 組織と異なる近赤外線の吸収パ夕ーンを呈すること を応用して脂質成分を同定する。Optical coherence tomography (OCT) とは異なり、血液や血栓の同定 や、ステントや石灰成分の裏側の評価も可能とされ る。近年、近赤外線と超音波を用いた血管内画像診 断装置であるNIRS-IVUSが臨床応用された。今回 我々は䅡動脈および鎖骨下動脈病変におけるNIRSIVUSのプラーク評価について報告する。

【方法】2017年4月から当院にて䅡動脈㧍よび鎖骨 下動脈病変に対してNIRS-IVUSを用いて血管内治 療を行った 16 例 (男性 12 例、平均年齢73歳)を対 象とした。NIRS-IVUSはInfraredx社の TVC-MC8 を用いた。治療前後でNIRS-IVUSでの評価を行い、 IVUSからはminimal luminal area (MLA)、plaque burden (PB)、 calcification等の評価を行い、NIRS からはlipid core burden index (LCBI)、 maximum LCBI (maxLCBI)、 maxLCBI inmlA等を評価した。 なお本研究は当院倫理委員会の承認のもと施行され た。

【結果】全例で治療前後にNIRS-IVUSでの評価が可能 であった。また石灰病変の裏側の脂質プラークの評 価も可能であった。治療前のmaxLCBIは䅡動脈狭 窄病変で $582 \pm 93$ と鎖骨下動脈狭窄/閉塞病変で 279 土100に比して有意に高值を示した。また治療前後 でmax LCBIの值は低下を認めた。

【結論】NIRS-IVUSによって脂質コアプラークの評 価が可能であった。頝動脈および鎖骨下病変におけ るNIRS-IVUSの臨床的有用性についてさらなる検 討が必要である。 


\section{時間分解分光法による近赤外線分光測定 装置(tNIRS)を用いた動眽管縮小前後の脳 循環のモニタリング}

埼玉県立小児医療センター 総合周産期母子医療セ ンター 新生児科

今西 利之、清水 正樹

【目的】定量性・再現性を持ち、組織中の酸素飽和度 (StO2) やHb濃度の絶対值を測定できる時間分解分 光法による近赤外線分光測定装置 (tNIRS ; time resolved Near Infra-Red Spectroscopy)を用いて、イ ンドメタシンによる動脈管縮小前後の脳循環をモニ タリングすること。

【方法】在胎 38 週 3 日、 $2820 \mathrm{~g}$ の動脈管開存症患者 に抒いて、インドメタシンを 24 時間毎に $0.25 \mathrm{mg}$ / $\mathrm{kg}, 0.2 \mathrm{mg} / \mathrm{kg}, 0.2 \mathrm{mg} / \mathrm{kg}$ の順に、それぞれ 30 分間 点滴静注した。動脈管の縮小は心臟超音波検査を 用いて確認した。治療の前後で浜松ホトニクス社 製tNIRS-1を左前額部に装着し、組織酸素飽和度 $(\mathrm{StO} 2) 、$ 総 $\mathrm{Hb}(\mathrm{tHb}) 、$ 酸化 $\mathrm{Hb}(\mathrm{O} 2 \mathrm{Hb}) 、$ 脱酸素 $\mathrm{Hb}$ （HHb）をサンプリングタイム5秒で測定した。

【結果】治療前のStO2は $48.67 \pm 1.64 \%$ 、tHbは39.61 $\pm 1.55 \mu \mathrm{mol} / \mathrm{L} 、 \mathrm{O} 2 \mathrm{Hb}$ は $19.29 \pm 0.87 \mu \mathrm{mol} / \mathrm{L} 、 \mathrm{HHb}$

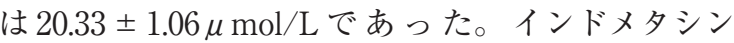
により経時的に各項目は改善し、治療後のStO2は $63.55 \pm 1.77 \%$ 、tHbは $43.77 \pm 0.84 \mu \mathrm{mol} / \mathrm{L} 、 \mathrm{O} 2 \mathrm{Hb}$ $27.85 \pm 1.15 \mu \mathrm{mol} / \mathrm{L} 、 \mathrm{HHb}$ は $15.92 \pm 0.73 \mu \mathrm{mol} / \mathrm{L} て ゙$ あった。動脈管の縮小により、 $\mathrm{tHb} 、 \mathrm{O} 2 \mathrm{Hb}$ が上昇 した結果、 $\mathrm{StO} 2$ も昇した。これは動脈管の縮小 前は動脈管の左右短絡を経由して減少していた脳血 流が、動脈管の縮小により左右短絡が減少し臟器血 液が増加したことで脳血流も増加し、脳循環におけ る酸素化も改善した結果を反映していると推測され た。

【結論】定量性と再現性をもつtNIRS-1の測定は動脈 管治療の際の脳循環のモニタリングに有用である可 能性がある。

\section{脳血流定量検查による中大脳動眽閉塞症 における側副血行路発達の推定}

${ }^{1}$ 東京女子医科大学 神経内科、 ${ }^{2}$ 東京女子医科大学 八千代医療センター 神経内科、 ${ }^{3}$ 東京女子医科大 学 画像診断・核医学科

○関 美沙 ${ }^{1}$ 、吉澤 浩志 ${ }^{1}$ 、内山由美子 ${ }^{2}$ 、 阿部光一郎 ${ }^{3} 、$ 北川 一夫 ${ }^{1}$

【目的】脳血流SPECT 定量検查ARG法は動脈採血を 入力関数とすることにより脳血流の絶対值を脳全 体で評価することが可能である。今回中大脳動脈 (MCA) 閉塞急性期例を対象に脳血流定量検查を施 行し、合わせて頭部MRAにより閉塞部位と側副血 行路の発達程度を評価した。

【対象】2016年6月～2017年 5 月に脳梗塞または一過 性脳虚血発作 (TIA)にて当科に受診した患者の中で、 MRAにて中大脳動脈起始部の高度狭窄ないし閉塞 を来していた4名を対象とした。脳血流SPECTは発 症より第7病日〜第16病日の間にARG法と graphplot法にて施行した。

【症例】症例 1 は 71 歳、女性。左上下肢の一過性脱 力を繰り返したため受診。MRIにて右頭頂葉に拡 散強調画像 (DWI) で高信号の梗塞巣を認め、DWI 陽性の一過性脳虚血発作 (TIA) と診断した。MRA にて右MCAのM1に高度狭窄を認めた。SPECTで は右MCA領域全体の血流低下を認めた。症例 2 は 48歳、女性。一過性の右顔面および右上肢のしび れ、吕律不良を自覚した。MRIにて梗塞巣を認めず TIA と診断した。MRAにて左MCA.M1に閉塞を認 め、SPECTにて左MCA前方領域の血流低下を認め た。症例 $3 は 64$ 歳、男性。一過性の右上肢脱力を自 覚し搬送。MRIにて梗塞巣を認めずTIAと診断した。 MRAにて左MCA.M1に高度狭窄を認めた。SPECT 上は左 $\mathrm{MCA}$ 、左前大脳動脈 $(\mathrm{ACA})$ 、左後大脳動脈 (PCA) 領域の血流低下を認めた。症例 4は63歳、男 性。左不全片麻疩にて発症し搬送。MRIにて右放 線冠に急性期梗塞巣を認め、MRAにて両側MCA. M1に高度狭窄を認めた。SPECTでは両側MCA、 ACA 領域の高度な血流低下を認めた。症例 4を除き、 MRA原画像ではいずれも病側でMCAは描出されず、 同側のPCAではより高位まで描出されていた。

【結論】MCA高度狭窄〜閉塞を伴うTIA症例で血管 支配領域の血流低下に伴い、同側のPCAによる側 副血行路の発達がみられた。 


\section{${ }^{99 m}$ Tc-ECD dynamic SPECT脳循環代謝 スクリーニングにおける留意点}

${ }^{1}$ 山形大学 医学部 脳神経外科、 ${ }^{2}$ 山形市立病院済 生館脳神経外科

○久保安昭 ${ }^{1}$ 、板垣 宽 ${ }^{1}$ 、山田 裕樹 ${ }^{1} 、$ 近藤 礼 ${ }^{2}$ 、佐藤 慎哉 ${ }^{1}$ 、園田 順彦 $^{1}$

【背景】我々は、より安全かつ沉用性の高い ${ }^{99 \mathrm{~m}} \mathrm{Tc}$ ECD dynamic SPECTの脳循環代謝評価における留 意点を ${ }^{15} \mathrm{O}-\mathrm{PET}$ との比較により検討したので報告す る。

【対象および方法】2011年11月以降施行した血行再 建術前患者及び脳血管障害86例を対象とした。dynamic SPECT は ${ }^{99 \mathrm{~m}} \mathrm{Tc}-\mathrm{ECD} 600 \mathrm{MBq}$ を急速静注 し、静注 0 分より 60 分間、 $360^{\circ}\left(180^{\circ} \times 2\right.$ 検出器 $)$ で 測定した。解析は最初の 2 分間は 30 秒毎、それ以 降は1分間毎で計60分間行った。 ${ }^{15}$ O-PETはsteady state法で施行した。画像解析は3DSRTを用い、 MCA領域のROI別に行った。

【結果】PET-CBFとdynamic ECDの比較ではROC 解析の結果、PET-CBF $20 \%$ 以上低下のECD (30-60 秒)のカットオフ值は7\%以上低下で感度 $87.5 \%$ 、特 異度 $72.7 \%$ であった。PET-OEF $10 \%$ 以上低下の ECD (14-16分)のカットオフ值は 4\%以上低下で感 度 $92 \%$ 、特異度 $82.4 \%$ であった。一方で、OEF と の比較では有意な傾向は認めなかった。dynamic ECDにおいて最初の2 分以内の変化が虚血側非虚血 側で逆転する症例があり、傾向としてCBVが上昇 していた。dynamic ECDの撮影時間は15分以降と それ以前で大きな差はなく、検査としては 15 分間 施行すれば問題なかった。

【結語】ECD dynamic SPECTは脳循環代謝スクリー ニング検査として有用であった。但し、血流評価が 軽度の場合、偽陰性になる可能性に留意が必要であ る。また、2分以内のearly phaseでの虚血側非虚血 側の逆転現象はCBVの上昇が影響している可能性 が示唆された。

\section{O-15迅速ガスPET検査における無採血化 ソフトウェアの開発}

${ }^{1}$ 国立循環器病研究センター 循環器病統合イメー ジングセンター、 ${ }^{2}$ 国立循環器病研究センター研究 所画像診断医学部、 ${ }^{3}$ 国立循環器病研究センター 脳血管内科、 ${ }^{4}$ 国立循環器病研究センター 放射線 部

$\bigcirc$ 井口 智史 ${ }^{1}$ 、越野 一博 ${ }^{2}$ 、圓見純一郎 ${ }^{2}$ 、 山本 明秀 $^{2}$ 、中川原譲二 ${ }^{1}$ 、梶本 勝文 $^{3}$ 、 飯田 秀博 ${ }^{4}$

PET検査では、動脈採血により血中の放射能濃度を 測定し入力関数を取得する場合が多いが、侵襲性や煩 雑さの問題点から動脈採血の排除が望まれている。脳 神経受容体のPET定量評価法ではsimplified reference tissue model等の動脈採血を要しない解析手法が広く

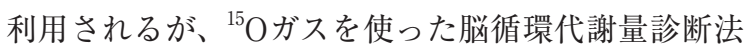
ではまた確立していない。当該研究者らは、内澒動脈 領域の時間放射能濃度 $(\mathrm{TAC})$ から入力関数を推定す る方法(Iguchiら、NIMA 2013)を報告したが、小さな 血管径ゆえに、MRI等を使った計算法の精度は十分高 くはなく、特に内澒動脈に病変を有する症例での限界 が示唆された。これらの問題を克服するために、血管 支配が異なる小脳領域などを参照して必要な一連の機 能画像計算の実施を補償する新規方法のプログラムを 開発し、この意義と実用的な精度の評価を行った。対 象は、すでに当該センターで臨床検査実施した健常 者 18 例、もやもや病症例 35 例、動静脈奇形症例 5 例、 一側性内頝動脈狭窄症例 8 例、合計 66 例である。一連 の ${ }^{15} \mathrm{O}_{2}-\mathrm{C}^{15} \mathrm{O}_{2}$ 連続吸入中のPET画像の内頸動脈にドー ナツ状ROIを設定し、かつ小脳領域のTACを参照し て、回復係数と spillover双方の補正を含む入力関数か ら ${ }^{15} \mathrm{O}$ ガス機能画像を取得し、すでに計算した機能画 像データと比較した。視覚的な画像比較に加え、関心 領域(VOI)を脳内の定められた15個の領域に設定して、 両者の絶対数值、および参照領域に対する相対值を比 較した。無採血法に基づく定量值は参照領域で仮定 した機能数值に依存して変化したが、参照領域に対す る相対值は、CBF值が $0.46 \pm 2.79 \% 、 \mathrm{CMRO} 2$ 值が 0.57 $\pm 3.03 \%$ 、OEF值が $0.06 \pm 2.19 \%$ (Mean $\pm \mathrm{SD}$ ) の差で あり、健常、虚血、梗塞、nidusの各領域を含む全領 域で両者良く一致した。内頝動脈錐体部の描出が必ず しも鮮明ではない症例が存在したが、本検討の中では 全症例で良く一致した。実用的な無採血検査法の確立 に貢献することが期待できる。 


\section{植込み型心電計にて心原性脳塞栓症と診 断しえた一例}

仙台市立病院 神経内科

$\begin{array}{cl}\text { ○遠藤 } & \text { 薰、滝口 真由、原田 龍平、 } \\ \text { 井上 } & \text { 彩、樋口じゅん }\end{array}$

症例は83歳男性で、薬剤溶出性冠動脈ステント留置 後のためアスピリン、クロピドグレル内服中であっ た。X年 8 月に5分間持続した左片麻痺発作で来院 し、MRIにて右中大脳動脈皮質領域に新規梗塞巣を 認め入院した。主幹脳動脈病変なく、経胸壁および 経食道心エコー、24時間心電図にて明らかな塞栓 源を指摘できず内服薬を変更せず退院した。9月に 突発するめまいにて入院し、翌日のMRIにて右後下 小脳動脈領域に新規梗塞を認めた。さらに入院 4 日 目の朝に言葉が出なくなり、MRIにて左中大脳動脈 領域皮質に新規梗塞を認めた。抗血小板薬 2 剂内服 下に塞栓症を 3 回発症していることから、潜在性の 発作性心房細動を疑い経口抗凝固薬に変更し、同月 にReveal LINQ (Medtronic社)を導入した。X+1年 5 月までの半年間に計 6 回の発作性心房細動を認め、 心原性脳塞栓症と診断した。動悸の自覚はなく、発 作は 1 月に 15 時間、 50 時間の 2 回、 3 月に 42 時間の 1 回、 4 月に 100 時間以上、 73 時間、 57 時間の 3 回と、 持続は比較的長いが月に数回しかなく、24時間心電 図で捉えることは極めて困難と考えられた。Reveal LINQは2016年 9 月に潜因性脳梗塞において心房細 動を検出するために使用可能となったが、24時間 心電図に比して長期間のモニタリングが可能であり、 本症例のような明らかな塞栓症を呈しているが塞栓 源の見出だせない症例において心房細動を検出する ために有用である。

\section{MELASの脳卒中様発作の経過観察に頭部 MRI-ASL画像が有用であった一例}

\author{
製鉄記念八幡病院 脳血管・神経内科 \\ ○坂井 翔建、日高 壮意、木村 俊介、 \\ 大崎 正登、荒川 修治
}

症例は53歳女性である。既往に感音性難聴、1型糖 尿病、慢性腎臓病などを有し、36歳時にA3243G変 異陽性のミトコンドリア病と診断されている。10日 前より歩行のふらつきを自覚し、前日には書類の枠 に自分の名前をうまく書けなくなったため来院した。 神経学的には右同名半盲と体幹失調を呈し、頭部 MRIではDWIで両側後頭葉皮質に高信号域を認め た。当初は脳梗塞を疑って抗血栓療法を開始したが、 第3病日のMRIではDWIの病変が血管支配領域を 超えて拡大しており、血液検查では乳酸・ピルビン 酸が上昇していた。MELAS (Mitochondrial myopathy、 encephalopathy、 lactic acidosis、stroke-like episodes）の脳卒中様発作と診断の上、L-アルギニ ンの静注療法を開始した。しかし症状は悪化し、純 粋失読やGerstmann症候群が出現した。DWIの高信 号域も左後頭葉から頭頂葉に及んで更に拡大してお り、同部位は脳血流SPECTで高灌流を呈していた。 レベチラセタムの内服を開始したところ症状は緩徐 に改善し始め、DWI上の高信号域は縮小し、ASL 画像での高灌流所見も経時的に消失した。MELAS の脳卒中様発作の病態として虚血性血管障害説や代 謝細胞障害説などの仮説が提唱されているが結論に は至っていない。本症例は神経細胞の興奮性立進の 関与が示唆される画像所見や治療経過であった。 


\section{急性期脳梗塞に対する血管内治療後に造 影剤による広範な白質脳症を呈した1 例}

日本医科大学 脳卒中治療科

○沓名 章仁、仁藤智香子、熊谷 智昭、 鈴木健太郎、荒川 将史、武井悠香子、 大久保誠二、木村 和美

脳梗塞、高血圧、糖尿病、慢性腎臓病の既往がある 76 歳の男性。発症時間不明の意識障害、左不全麻 痺、右共同偏倚を認め、脳卒中疑いで当院救急搬送 となった。入院時NIHSSスコアは14点。頭部MRI にて右中大脳動脈領域の急性期虚血巣、頭部MRA にて右中大脳動脈M2の描出不良を認め、血管内治 療を施行する方針とした。閉塞部でステントリト リーバーを展開し、再開通後に著明な壁不整がみ られ、アテローム血栓性と考え、狭窄部に対してバ ルーン拡張を施行した。Thrombolysis in Cerebral Infarction Grade 2Bの部分再開通が得られたが、術 後頭部CTにて脳溝に沿って高吸収域を認め、意識 障害の悪化、全般性痤攣発作が出現し、抗痤攣薬投 与で痤攣発作は消失した。3時間後の頭部CTにて高 吸収域は消失しており、造影剂脳症と考えた。第 2 病日の頭部MRIでは梗塞巣と一致しない同側の広範 な白質脳症を認め、また血液検査にて造影剤腎症を 合併した。急性白質脳症に対してステロイドパルス 療法を開始し、第3病日をピークにして画像所見は 軽快傾向となった。症状はやや軽快し、第30病日 に回復期病院へ転院となった。転院時のNIHSSスコ アは12点、modified Rankin Scaleは5であった。造 影剂脳症は非イオン性造影剂による稀な合併症であ り、特に血管内治療後の報告が散見される。症状は 皮質盲が多く、数日で軽快する事が多いと言われて おり、血液脳関門の破綻の関与が示唆されている。 本症例では広範な片側白質脳症を呈し、ステロイド パルス療法で画像所見はやや改善したものの、症状 は遷延した。急性期血管内治療後に造影剤による片 側白質脳症を認めた稀な症例と考えられ、文献的考 察を加えて報告する。

\section{Bihemispheric ACAの狭窄により発症し た両側ACA領域梗塞の一例}

\author{
広南病院 脳血管内科
}

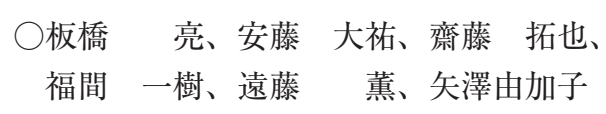

症例は65歳男性。喫煙、高血圧、糖尿病と脂質異 常がある。X-1年 11 月より両下肢脱力を自覚してい た。12月より症状が悪化しA病院にて入院加療し塞 栓症としてワルファリンが開始された。精査目的 に当科紹介となりX年 1 月に当科に入院した。神経 学的には両下肢の軽度筋力低下を認めた。MRIで 両側前大脳動脈 (ACA) 領域に多発する梗塞巣を認 め、MRAではbihemispheric である左ACA のA2に 高度狭窄を認めた。SPECTでは両側前頭葉を中心 に集積低下を認めた。アテローム血栓性梗塞の診断 でワルファリンは終了し、危険因子への介入と抗血 小板薬投与を行った。ACAの皮質枝分布には多く のvariationがある。片側が両側pricallosal artery領 域を灌流し、一方がcallosomarginal artery領域の みを灌流する場合、bihemispheric ACAと呼ばれそ の頻度は $12 \%$ とされている。ACAが全長にわたっ て融合している場合はazygos ACA、一部であれば unpaired ACAと分類される。本例は一見unpaired ACAであるが右ACAがcallosomarginal artery領域 前方を灌流していることから bihemispheric ACA とした。両側ACA領域に同時に梗塞を発症した場 合両側下肢脱力を生じ得ることは知られているが、 bihemispheric、 unpairedもしくはazygous ACAの 狭窄により両側ACA領域梗塞を発症した症例報告 は渉猟した限り稀であり、注意すべき病態と考え報 告する。 


\section{動眽血栓症を繰り返し、頸動眽ステント 内に血栓が生じたプロテインC欠乏症の1 例}

${ }^{1}$ 川崎医科大学附属病院臨床教育研修センター、 ${ }^{2}$ 川崎医科大学脳卒中医学、 ${ }^{3}$ 川崎医科大学脳神経 外科学、 ${ }^{4}$ 大阪大学大学院医学系研究科神経内科学

○岩本侑一郎 ${ }^{1}$ 、北野 貴也 $^{2,4}$ 、岩本 高典 $^{2}$ 、 城本 高志 ${ }^{2}$ 、久保 智司 ${ }^{2}$ 、植村 順一 $^{2}$ 、

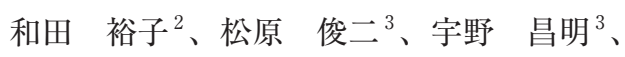
八木田佳樹 ${ }^{2}$

【症例】40歳、女性。

【既往歴・薬歴】X-7年に右中大脳動脈領域の脳梗 塞。 4 回経妊、3 回経産。月経不順に対して入院 7 日 前より中用量ピルを内服していた。

【家族歴】父親が 60 歳代で脳梗塞を 3 回。

【嗜好歴】過去喫煙者、34歳以降禁煙。飲酒なし。 【現病歴】X年 3 月上旬朝に左上下肢の脱力を自覚し たが1時間程度で軽快した。翌日の午前 7 時に起床 した時、再度左上下肢の脱力を自覚したため救急要 請し、当院へ搬送された。入院時には左口角下垂、 左不全片麻痺、左半側空間無視を認めた。頭部MRI では右中大脳動脈領域の急性期脳梗塞を認め、頭 部MRA上、右中大脳動脈は水平部で閉塞していた。 緊急脳血管造影を施行し、右中大脳動脈水平部の蟹 爪状閉塞を認めた。右内頚動脈起始部には血栓透亮 像と思われる造影不良域を認めた。主幹動脈閉塞に よる超急性期脳梗塞と診断し、血行再建術を行った。 右内頸動脈ステント留置術および右中大脳動脈血栓 回収術を施行し、TICI2aの部分再開通を得た。来 院時よりアスピリンとクロピドグレルによる抗血小 板療法を行っていたが、第3病日に施行した造影頸 動脈超音波検査で右内頝動脈ステント内に血栓を認 めたため、直ちにへパリンの投与を開始した。入院 時の血液検査でプロテインCが抗原量、活性ともに 低值であり、プロテインC欠乏症と診断した。術後 に脳梗塞の再発はなく、ヘパリンをワルファリンに 変更して抗凝固療法を継続し、第 23 病日に独歩で 自宅退院した。第62病日に施行した脳血管造影検 査ではステント内血栓は消失していた。

【結語】動脈血栓症を繰り返し、頸動脈ステント内に 血栓が生じたプロテインC欠乏症の1例を経験した。 ステント内血栓症の発症に血栓性素因が関与するこ とを示唆する症例と考えられる。

\section{頭部外傷後に中枢性塩類喪失症候群を呈 したと考えられる2症例}

県立広島病院 脳神経内科

$\begin{array}{cl}\text { ○山田 } & \text { 英忠、向井 } \\ \text { 智哉、棚橋 梨奈、 } \\ \text { 博満、時 信弘 }\end{array}$

頭部外傷後に著明な低Na血症を認めた 2 例を経験し たため報告する。

【1例目】86歳の女性。2017年X月中旬に転倒によ る頭部打撲に対し、近医脳神経外科にて経過観察 していた。X-1月末ごろより物忘れの進行と頭部 CTでの脳室拡大を認め、X月 4 日に当院に精査入 院した。入院時、JCS I -3の意識障害を認め、血清 $\mathrm{Na} 122 \mathrm{mEq} / \mathrm{L}$ あった。生理食塩水にて 200 から $277 \mathrm{mEq} / \mathrm{L} /$ dayのNa補充を行い、血清Na 130mEq/ Lまで改善した。頭部外傷後に発症したCSWSと考 えられた。グリセリン加糖配合液点滴による保存的 加療後に転院した。

【2例目】51歳の女性。2017年 X-1月に交通事故 による多発外傷にて入院し、外傷性クモ膜下出 血、脾損傷などに対し加療した。入院時の血清 $\mathrm{Na}$

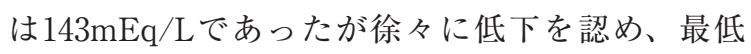

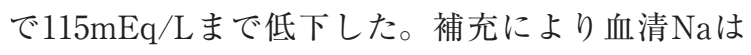
$136 \mathrm{mEq} / \mathrm{L}$ まで改善し、自宅退院した。退院後、め まいと嘔気を訴えX月15日に救急外来を受診した。 血清Naは $118 \mathrm{mEq} / \mathrm{L}$ 著明に低下しており、生理食 塩水にて $154 \mathrm{mEq} / \mathrm{L} / \mathrm{day}$ の $\mathrm{Na}$ 補充を行った。一時 的に血清Naは改善したが、補充を中止したところ 血清 $\mathrm{Na} 123 \mathrm{mEq} / \mathrm{L}$ 再度低下を認めた。近医病院 での加療を希望され、X月28日に転医した。

【まとめ】頭蓋内疾患により尿中 $\mathrm{Na}$ 排泄の異常立進 を来す疾患群として、中枢性塩類喪失症候群 (cerebral salt wasting syndrome: CSWS) が挙げら れる。一方、ADHが不適切に分泌される疾患とし てSIADH (syndrome of inappropriate secretion of ADH) が挙げられるが、しばしば鑑別が困難である。 CSWSは低ナトリウム血症の患者における重要な鑑 別疾患であり、頭部外傷を含めた詳細な病歴聴取が 必要と考えられた。 


\section{${ }^{15}$ OガスPETを用いたラットの脳潅流圧の 定量的評価}

\author{
${ }^{1}$ 大阪大学大学院 医学系研究科核医学講座、 \\ ${ }^{2}$ 大阪大学大学院 医学系研究科 医薬分子イメージ \\ ング学寄附講座
}

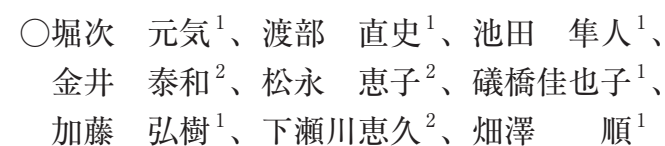

【目的】脳虚血モデルを用いた前臨床研究では、脳灌 流圧を評価することが極めて重要である。本研究の

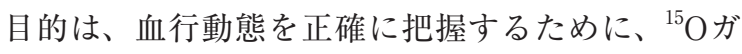
スPETを用いて脳潅流圧の分布を評価することであ る。

【方法】正常 $\mathrm{SD}$ ラット $(\mathrm{n}=6)$ )、脳虚血 (MCA occlusion) モデル $(\mathrm{n}=2)$ を用いて ${ }^{15} \mathrm{O}$ ガス $\mathrm{PET}$ を行った。 脳血流 $(\mathrm{CBF})$ は ${ }^{15} \mathrm{O}-\mathrm{CO}_{2}$ ガス $(400 \mathrm{MBq} / \mathrm{min})$ による steady state法、脳血液量 $(\mathrm{CBV})$ は ${ }^{15} \mathrm{O}-\mathrm{CO}$ ガス $(200$ $\mathrm{MBq} / \mathrm{min})$ を用いて動脈採血による定量計測を行っ た。関心領域は脳テンプレートを用いて自動的に設 定した。脳の各領域に扔ける脳潅流圧指標として $\mathrm{CBF} / \mathrm{CBV}$ 算出した。

【結果】正常ラットの全脳の定量值はCBFが52.9 $10.3 \mathrm{ml} / 100 \mathrm{ml} / \mathrm{min} 、 \mathrm{CBV}$ が $5.66 \pm 0.34 \mathrm{ml} / 100 \mathrm{ml}$ 、CPP が9.4 $\pm 2.2 / \mathrm{min}$ であった。線条体 $(17.5 \pm 3.7 / \mathrm{min}) 、$ 視床 $(20.4 \pm 4.0)$ 、中脳 $(18.8 \pm 3.3)$ における脳潅流 圧指標は前頭皮質 $(7.2 \pm 2.2)$ 、視覚野皮質 $(6.9 \pm$ 2.1)、小脳 $(9.5 \pm 2.7)$ 上りも有意に高く、脳灌流圧 の分布に差を認めた $(\mathrm{p}<0.01)$ 。また脳虚血モデル では閉塞側のMCA 領域に脳灌流圧指標の低下を認 めた。

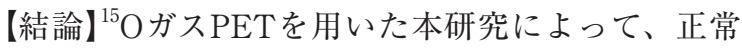
ラットの脳潅流圧に大きな領域差があることが明ら かになった。虚血モデルを評価する際には注意を要 する。

\section{小動物用PET-CTを用いた慢性脳低灌流モ デルラットの脳血流および脳酸素代謝評} 価

${ }^{1}$ 大阪大学大学院 医学系研究科 核医学講座、

${ }^{2}$ 大阪大学大学院医学系研究科 医薬分子イメージ ング学寄附講座

加藤 弘樹 $^{1}$ 、渡部 直史 $^{1}$ 、金井 泰和 $^{2}$ 、 堀次 元気 ${ }^{1}$ 、烟澤 順 $^{1}$

ラット慢性脳低灌流モデルにおける脳血流、脳酸素 代謝分布の変化に関するin vivoでの画像評価はこ れまでに行われることがなく、明らかになっていな い。筆者らは小動物用PET-CT装置を用いてラット の脳循環代謝をin vivo評価する方法を開発し、正常 ラットの脳内分布を評価してきた。当研究では両側 総澒動脈結紮による両側総䅡動脈閉塞モデルラット (BCAO) に関して、脳循環、脳酸素代謝分布を急性 期および慢性期において評価することを目的とした。 イソフルラン麻酔下にてモデル作成およびSham手 術を行った。急性期 (術後 1 週) および慢性期 (術後 6 週)におけるBCAOモデルおよびShamラットに対し て、ミタゾラム等による麻酔下で、小動物用PETCT装置を用いてO-15 PET steady state法による脳 循環、脳酸素代謝評価を行った。その結果、急性期 のBCAOではShamに比して特に大脳において有意 な $\mathrm{CBF}$ 低下、有意な $\mathrm{OEF}$ 上昇が認められた。一方、 慢性期においては両者の差は縮小したもののBCAO ではShamに比して特に前頭部においてCBFの低下、 CMRO2の低下が認められた。O-15 PETによるin vivo画像評価によって、ラット慢性脳低灌流モデル に拉ける麻酔下での脳循環、脳酸素代謝分布が明ら かになった。 


\section{L-[3- $\left.{ }^{11} \mathrm{C}\right]$ Lactate PETによる乳酸のイン ビボ脳内動態解析}

${ }^{1}$ 大阪薬科大学 生体分析学研究室、 ${ }^{2}$ 国立循環器病 研究センター研究所 画像診断医学部、 ${ }^{3}$ 京都薬科 大学 放射性同位元素研究センター

\section{$\bigcirc$ 天滿敬 ${ }^{1,2}$ 、河嶋 秀和 ${ }^{2,3}$ 、近藤 直哉 ${ }^{1,2}$ 、 山崎 真 ${ }^{2}$ 、越野 一博 ${ }^{2}$ 、飯田 秀博 $^{2}$}

【目的】近年脳において乳酸がエネルギー基質やシグ ナル伝達物質となる可能性が指摘されているが、生 体脳を用いた明確な報告例はない。そこで我々はイ ンビボでの非侵襲的生体分析に適したポジトロン断 層撮像法(PET)に着目し、PET用プローブL- $\left[3-{ }^{11} \mathrm{C}\right]$ Lactateの合成を行った後、ラットを用いた血中代 謝物分析とインビボ動態解析を試みた。

【方法】既報に従いD,L- $\left[3-{ }^{11} \mathrm{C}\right]$ Alanineを合成した後、 酵素混合液と $45^{\circ} \mathrm{C}$ で5分間反応することにより L- [3$\left.{ }^{11} \mathrm{C}\right]$ Lactateを得た。光学純度はHPLC法にて調べた。 L- [3- $\left.{ }^{11} \mathrm{C}\right]$ Lactateを正常SDラットに尾静脈内投与 し血中での化学形を $\mathrm{pH}$ 異なる二溶液間での放射 能比率およびHPLC法により調べた。通常あるいは 絶食処置したSDラットにL- $\left[3-{ }^{11} \mathrm{C}\right]$ Lactateを尾静 脈内投与し頭部PET撮像を行った。投与 10 分まで のデータを用いコンパートメント解析を行った。

【結果・考察】酵素法により L- $\left[3-{ }^{11} \mathrm{C}\right]$ Lactateを所要 時間 50 分、放射化学的収率 $13.4 \%$ 、放射化学的純 度 $95 \%$ 以上、光学純度 $99 \%$ 以上で得た。L- $\left[3-{ }^{11} \mathrm{C}\right]$ Lactateの尾静脈内投与後、血中放射能は速やかに 消失し、投与 10 分後における血中放射能は $10 \%$ が 未変化体、67\%はD- $\left.{ }^{11} \mathrm{C}\right]$ Glucoseであった。投与 60 分後における血中放射能は $13 \%$ が $\left[{ }^{11} \mathrm{C}\right] \mathrm{CO}_{2}$ で あった。PETデータを用いたコンパートメント解析 により算出した脳への移行速度定数は通常ラットと 比べ絶食処置ラットにおいて有意に高い值を示した ことから、絶食処置条件下において乳酸が脳エネル ギー基質となる可能性を示した。

【結語】 L- $\left[3-{ }^{11} \mathrm{C}\right]$ Lactateの合成法を開発し血中代 謝物分析を行うことによりインビボPET脳内動態解 析のための基盤構築に成功した。
マウス脳梗塞モデルにおける生体内酸化 ストレスイメージング

岡山大学病院神経内科

$\begin{array}{crrr}\text { ○中野由美子、山下 } & \text { 徹、太田 } & \text { 康之、 } \\ \text { 佐藤 } & \text { 恒太、森原 } & \text { 隆太、商 } & \text { 敬偉、 } \\ \text { 菱川 } & \text { 望、阿部 } & \text { 康二 }\end{array}$

Nuclear factor erythroid 2-related factor 2 (Nrf2) は脳虚血再灌流障害の際に生じる酸化ストレスに対 して働く、生体内の重要な細胞防御機構である。本 研究では、酸化ストレス可視化遺伝子改変動物であ る OKD (Keap1-dependent oxidative stress detector) マウスを用いて、脳梗塞モデルを作成し、脳虚 血再灌流後に生じる脳内酸化ストレス動態を経時的 に追った。右総頸動脈からシリコンコーティングし た塞栓子を挿入し、右中大脳動脈を 45 分間閉塞す ることにより脳梗塞を誘発し、塞栓子の抜去により 再灌流を生じた後 12 時間、1日、3 日、7日目にそ れぞれIVISシステムを用いてin vivo imagingを行っ た。各タイムコースで脳のサンプリングを行い、脳 梗塞体積と免疫組織学的評価を行った。その結果、 in vivoシグナルは再灌流1日目にピークに達し、シ グナル強度は脳梗塞体積と相関し、3日目には減衰 し、7日目には消失した。再灌流1日目に施行した ex vivo imagingでは、脳梗塞中心部に比して、脳 梗塞周辺部でより強いシグナル変化が認められ、免 疫組織学的評価における、内在性のNrf2 の発現分 布と一致した。細胞別の内在性のNrf2の発現分布を みると、ニューロンで明らかに多く、次いでオリゴ デンドログリアやアストロサイト、ペリサイトなど での発現が観察された。ミクログリアや血管内皮細 胞での発現はわずかであった。本研究では生体内の 酸化ストレスを経時的に観察でき、この時間的変化 は組織学的なNrf2の発現動態とも一致した。本研究 により確立した酸化ストレス可視化脳梗塞モデルを 用いることで、急性期治療としての薬物効果判定な どに有用である可能性が示された。 


\section{新生児脳梗塞に対する臍帯血CD34 陽性 細胞治療 : モデルマウスにおける検討}

${ }^{1}$ 国立循環器病研究センター 再生医療部、 ${ }^{2}$ 先端医 療センター 再生医療研究部、 ${ }^{3}$ 兵庫医科大学 先端 医学研究所 神経再生研究部門、 ${ }^{4}$ 国立循環器病研 究センター 脳血管内科

\section{○过 雅弘 ${ }^{1} 、$ 田口 明彦 ${ }^{2}$ 、大嶌麻妃子 ${ }^{1} 、$

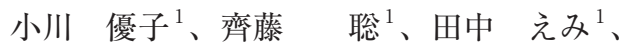 松山 知弘 $^{3}$ 、猪原 匡史 ${ }^{4}$ 、斯波真理子 ${ }^{1}$}

【目的】出生前後・新生児期に起こる急性脳障害のほ とんどは虚血性障害(循環障害)であり、その内、脳 梗塞は低酸素性虚血性脳症に次いで多く、新生児脳 梗塞の頻度は約 4000 出生に 1 例である。発症時期が 不明なことが多く、治療開始猶予期間の長い新規治 療法開発が望まれている。そのような治療として近 年、細胞治療が注目されているが、早期臨床応用の し易さから我々は臍帯血幹細胞治療に着目した。本 研究の目的は、新生児脳梗塞に対して臍帯血幹細胞 治療が有効かどうかをモデルマウスを用いて検証す ることである。

【方法】日齢 12 (ヒト出生 0 日に相当)の免疫不全 (SCID) マウスを用いて片側中大脳動脈永久閉塞 (MCAO) モデルを作製した。48時間後にヒト臍帯 血CD34 陽性細胞 (造血幹細胞・血管内皮前駆細胞) 1x10 ケを静脈内投与した $(\mathrm{MCAO}+\mathrm{UCBCs}$ (umbilical cord blood cells)群)。対照群にはPBSを投与し た(MCAO+PBS群)。脳血流測定、行動試験を順次 行い、7週後に脳を取り出し形態的障害を評価した。 また、治療の 24 時間後に脳を急速凍結しイメージ ング質量分析を行った。

【結果】細胞投与 24 時間後にペナンブラ領域での 血流改善を認め、ロータロッド試験において運動 機能の改善を認めた (Sham-surgery群 $238 \pm 24$ 秒、 MCAO+PBS 群 $175 \pm 49$ 秒、MCAO+UCBCs 群 203 \pm 54 秒)。大脳半球体積減少率も有意に軽減した (MCAO+PBS群 $25.6 \pm 5.1 \% 、 \mathrm{n}=12 、 \mathrm{MCAO}+\mathrm{UCBCs}$ 群 $21.5 \pm 1.9 \% 、 \mathrm{n}=10)$ 。投与細胞は24時間後におい て脳内にごく少数(冠状断切片の大脳全域に数ヶ)し か認めなかった。イメージング質量分析では梗塞周 囲領域において幾つかの化合物の増加を認めた。

【考察】新生児脳梗塞に対して臍带血CD34 陽性細胞 治療は有効であることが示された。その作用機序と しては、投与細胞による細胞置換ではなく、投与細 胞による脳血流改善や脳内代謝の改善が示唆された。

\section{脳血流・温度同時イメージングによる脳 循環代謝の時空間解析}

京都大学 学際融合教育研究推進センター 健康長寿 社会の総合医療開発ユニット

○鈴木 崇士、大石 直也、福山 秀直

脳温は、脳での代謝立進による熱産生と、脳血流に よる熱輸送のバランスによって決定される。した がって、脳血流および脳温度の両方を同時に画像化 することは、Neurovascular-metabolic couplingを 理解する上で重要であると考えられる。我々はこれ までに、レーザースペックル血流イメージングと脳 温度イメージングによる脳血流と代謝の同時計測シ ステムを開発した。本研究では、ラット脳の血流お よび温度イメージそれぞれの各ピクセルにおける時 系列変化の相関係数を画像化することにより、脳血 流と代謝の時空間パターンについて調べたので報告 する。 


\section{多光子顕微鏡による脳内アミロイド $\beta$ 動 態の観察}

大阪市立大学大学院 医学研究科 神経内科

○平良 庸子、安部 貴人、伊藤 義彰

【背景】アミロイド $\beta$ は血液脳関門を通過しにくく、 脳実質から血管内に排出される経路としては、毛細 血管の脳実質側から内腔側へトランスサイトーシス により排出輸送される経路、血管周囲リンパ排液路 を介して髄液中に排出される経路などが想定されて いるが、いまだに詳細は不明である。今回我々は、 多光子顕微鏡により脳内に投与した標識アミロイド $\beta$ の動態の観察を試みた。

【方法】イソフルラン麻醉下で雄性C57/BL6マウスの 左側頭頂部の頭皮を切除し、頭骨 (径 $3.5 \mathrm{~mm}$ )を除去 した。脳表にHiLyte-488アミロイド $\beta 1-40$ (Anaspec) 及びHiLyte-488アミロイド $\beta$ 1-42 (Anaspec)を滴下 し、その後カバーグラスによって閉鎖頭空を作製し た。またsulforhodamine 101 (5 mM in saline、Dojindo) をマウス腹腔に投与 $(8 \mathrm{ml} / \mathrm{kg}$, i.p.) し、血漿成 分を蛍光標識した。多光子顕微鏡による脳微小血管 周囲の反復イメージングを行った。

【結果】sulforhodamine投与により鮮明な血管の形 態画像が得られた。アミロイド $\beta$ を滴下してから 2 時間後に脳表から約 $400 \mu \mathrm{m}$ 付近の脳実質において、 アミロイドが血管周囲に沿って存在しており、滴下 したアミロイド $\beta$ が血管周囲リンパ排液路を介して 排出されている可能性が示唆された。アミロイド $\beta$ 1-40とアミロイド $\beta 1-42$ とのクリアランスの差は見 られなかった。

【結語】多光子顕微鏡により、脳表に滴下したアミロ イド $\beta$ のリアランス過程をリアルタイムで可視化 しうると考えられた。病態解明のツールに成りうる と思われる。

\section{新規脳梗塞霊長類マーモセットモデルの 開発}

\footnotetext{
${ }^{1}$ 東京慈恵会医科大学 神経内科、 ${ }^{2}$ 東京慈恵会医科 大学 再生医学研究部、 ${ }^{3}$ 東京慈恵会医科大学 実験 動物研究施設、 ${ }^{4}$ 理化学研究所 脳科学総合研究七 ンター

○小松 鉄平 ${ }^{1} 、 太$ 田 裕貴 ${ }^{2}$ 、小泉 誠 ${ }^{3}$ 、 畑 純一 ${ }^{4}$ 、岡野 ジェイムス 洋尚 ${ }^{2}$ 、

井口 保之 ${ }^{1}$
}

従来脳梗塞のモデル動物としてはマウスやラットと

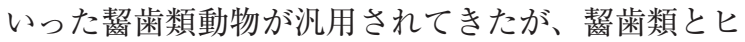
卜は系統学的に離れているため、瓃歯類で得られた 研究結果をすべて直接ヒトに当てはめることはでき ない。脳梗塞新規治療薬の前臨床試験において䠘歯 類モデルは限界であり、小型霊長類であるマーモ セットに期待が寄せられている。マーモセットは瞝 歯類と比較して、脳血管系、脳代謝、灰白質/白質比、 行動様式がヒトに近い。ラットと同様に小型で扱い やすく、生きたままMRI検査を行うことが可能であ るにも関わらず、脳の大きさはラットの 4 倍になる。 また繁殖能力の高さも特徵であり、生後約 1 年で性 成熟に達し、一回の出産で約 2 匹の仔を年間 2 回出 産する。生涯産仔数は 40 ～80匹と繁殖効率が高く、 実験動物として適している。またこれまでの一般的 な䛚歯類脳梗塞モデルは、外頸動脈からナイロン糸 を盲目的に扦入し中大脳動脈及びその近傍の血管を 一時的に閉塞させる方法であるため、梗塞範囲が安 定せず、頸部を大きく切開する上、外頸動脈を結係 するため手術侵襲が高いことが問題である。また脳 梗塞に対する骨髄間葉系幹細胞の静脈投与による治 験が開始されているが、静脈投与では肺など目的外 臓器に取り込まれ治療効果が減弱するため神経再 生作用は乏しく、経動脈的細胞投与が期待されるが 検証可能な脳梗塞動物モデルは存在しない。我々は デジタルサブトラクション血管造影装置を用いて超 低侵襲にマーモセットの脳血管撮影をすることに成 功した。術後は全例において全身状態良好で安全に 血管造影が行えることを確認した。本法を発展させ、 超低侵襲かつ標的血管選択性の高い、そして繰り返 し経動脈的細胞投与が可能な新規脳梗塞霊長類モデ ルを確立する。 


\section{脳梗塞後のCD44の局在と傷害誘導性多 能性幹細胞の分化}

${ }^{1}$ 関西学院大学理工学研究科生命科学専攻、 ${ }^{2}$ 兵庫 医科大学先端医学研究所神経再生研究部門

○澤田里佳子 ${ }^{1}$ 、松山 知弘 ${ }^{2}$ 、中込 隆之 ${ }^{2}$ 、 土居亜紀子 ${ }^{2}$ 、佐久間理香 ${ }^{2}$ 、蒲池紗栄子 ${ }^{2}$ 、 高橋 愛 ${ }^{1}$

【背景】CD44は、ヒアルロン酸などをリガンドとす る接着分子であり、本研究室で発見された、脳梗塞 後に誘導される内因性の多能性幹細胞である虚血 ペリサイト $(\mathrm{iPC}) に も$ 発現していることが明らかと なっている。

【方法】本研究では、脳梗塞後の梗塞巣内でのCD44 陽性細胞の局在を検討するため、脳梗塞後 6 時間、 1日、3日、5日、7日のマウス脳梗塞モデルを用 い、脳を固定後、脳切片を作成した。この脳切片を CD44およびPDGFR- $\beta$ 、nestin、Iba1、CD206抗体 を用いて免疫組織化学染色を行った。また、脳梗塞 巣からiPCを単離・培養し、免疫組織化学染色にお いてタンパク質発現を確認した。さらに、培養細胞 をオリゴデンドロサイト分化培地、神経誘導培地に おいて分化誘導し、MAG、Tuj1、Iba1にて免疫組 織化学染色を施行した。

【結果】脳梗塞 3 日目まではCD44は血管周囲とペナ ンブラに発現し、血管周囲ではnestin とPDGFR- $\beta$ を、ペナンブラではCD206を共発現する細胞が多い ことが明らかとなった。また、5日目、7日目の脳 切片ではCD44は血管周囲・ペナンブラだけでなく 脳梗塞巣全体に分布し、その多くがIbalを発現して いる様子が観察された。正常領域においては、いず れの時期においても、CD44陽性細胞の発現はほと んどみられなかった。また、培養したiPCはCD44、 PDGFR- $\beta$ 、nestinを発現しており、MAG、Tuj1、 Ibal 陽性細胞へ分化することが明らかとなった。

【結論】CD44陽性細胞は正常領域ではなく、主に 梗塞領域のiPCやミクログリア・マクロファージに 発現していると考えられた。また単離したCD44陽 性iPCは幹細胞のマーカーであるnestinを発現して おり、神経系やミクログリアへ分化したことから CD44は傷害誘導後の多能性幹細胞の有用なマー カーであると考えられた。

\section{脳梗塞後のオリゴデンドロサイト前駆細 胞の役割について}

${ }^{1}$ 京都大学大学院 脳神経外科学、 ${ }^{2}$ 京都大学大学院 臨床神経学

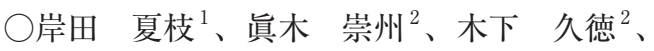
安田 謙 ${ }^{2}$ 、高木 康志 ${ }^{1}$ 、高橋 良輔 $^{2}$

【目的】オリゴデンドロサイト前駆細胞 (oligodendrocyte precursor cell、OPC) は脳内に広範囲に存在す るグリア細胞で多様な役割を担っている。ミエリン 鞘を形成するオリゴデンドロサイトの供給源という だけでなく、神経系や血管系、他のグリア細胞との 相互作用を介して脳恒常性維持に寄与していること が近年明らかとなってきた。しかしながら脳虚血下 でのOPCの㗢きについてはまだ明らかではない。今 回我々は、OPCが脳梗塞後の過程においてどのよう な動態を示すのかを検討した。

【方法】C57/BL6 マウスを用い、脳梗塞モデル (MCAO) モデルを作成した。免疫蛍光染色を行い、 脳梗塞後day1、3、7、14、28に扔ける OPCの変化 を調べた。またラットOPC初代培養を用いて、低酸 素負荷 (OGD負荷)をした後の反応性OPCにおける RNA-seq解析を行った。

【結果】脳梗塞後の虚血領域においてday1ではOPC は減少したが、day3から14にかけて血管周囲の OPCは増加していた。血管内皮細胞も OPC と同 様、day1で減少する一方でday3より増加していた。 OGD負荷後のOPCでは、多くの遺伝子発現が変動 し、OPCの表現型が虚血負荷により大きく変化する ことが示唆された。

【結論】脳梗塞後においてOPCが血管系の修復過程に 関与する可能性が考えられた。詳細な機序や神経系、 他のグリア系への影響については今後の検討が必要 である。 


\section{穿刺SAHモデルマウスにおけるくも膜下 出血に伴う虚血性変性の評価}

\author{
${ }^{1}$ 秋田県立脳血管研究センター、 ${ }^{2}$ 東北大学加齢医 \\ 学研究所
}

○中村 和浩 ${ }^{1,2}$ 、佐々木一益 ${ }^{1,2}$ 、石川 達哉 ${ }^{1}$

【目的】くも膜下出血 (SAH) の病態を解明するため、 内頸動脈から扱入したナイロン糸により、前大脳動 脈を穿刺し脳底全体に出血させる動物モデル (穿刺 SAHモデル)が使用されている。穿刺SAHモデルは 臨床病態に近い出血形態を示すものの、しばしば急 性虚血性変性がいくつかの解剖学的部位において観 察される。そこで、我々は穿刺SAHモデルにおけ る虚血性変性の発生頻度やその発生部位について検 討した。

【方法】雄性マウス (C57BL/6,9週令) に対して、穿刺 SAHモデルを適用した。虚血性変性は、4.7T 動物 用MRI装置により、SAH 1 日後の拡散強調磁気共鳴 画像 (DWI)を取得し評価した。また、SAH後 1 時間 以内の連続動脈スピンラベリング法によって脳血流 量 $(\mathrm{CBF})$ を評価し、3次元 $\mathrm{T} 2$ *強調画像から、既報 の視覚的な分類に従いSAHをGrade 1から Grade 4 まで4段階に分類した。

【結果・考察】SAH 1 日後のDWIでは、72匹のマウ スのうち37匹について、いずれかの部位で虚血性 変性が認められた。出血量の少ないGrade 1 が4例、 出血量の多いGrade4が21例であり、その中間とな るGrade2、Grade 3はそれぞれ、17例と26例であっ た。虚血性変性の発生部位は同側皮質 $(\mathrm{n}=12)$ 、尾

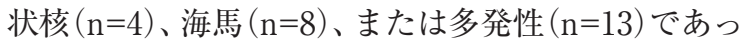
た。虚血性変性の有無によって、SAH直後のCBF には有意な差が認められなかった。また、虚血性変 性は出血量の多い群において多く認められた。これ らの結果から、穿刺SAHモデルでは、SAHに伴う 脳圧の上昇により、虚血性変性が生じているもの と推察される。特に、頭蓋内容積の小さいマウスで は、虚血性変性の発生頻度が高くなる傾向にあるも のと考えられた。発症直後に死亡するような重度の SAH患者では脳圧立進に伴い、動物モデル同様の 広範囲な急性虚血が生じているとも考えられ、穿刺 SAHモデルは、重症SAH患者に扔ける突然死の根 底にあるメカニズムを解明するのに役立つ可能性が ある。

\section{S1P signaling in neuronal apoptosis ; links to resistance and vulnerability to ischemic cell death}

\author{
${ }^{1}$ 東北大学 大学院 医学系研究科 神経外科学分 \\ 野、 ${ }^{2}$ 東北メディカル・メガバンク機構 ゲノム解 \\ 析部門、 ${ }^{3}$ 広南病院 脳神経外科、 ${ }^{4}$ 東北大学 加歯令 \\ 医学研究所 プロジェクト研究推進分野
$\bigcirc$ Rashad Sherif ${ }^{1}$ 、新妻 邦泰 $^{1}$ 、三枝 大輔 $^{2}$ 、 韓 笑波 ${ }^{1}$ 、前田 美香 ${ }^{1}$ 、藤村 幹 ${ }^{3}$ 、 井川俊太郎 ${ }^{4}$ 、冨永 悌二 ${ }^{1}$

Sphingosine-1-phosphate (S1P) is a sphingolipid molecule produced by the action of Sphingosine kinase (SphK)1 and 2 on Sphingosine, and it possesses wide range of intracellular functions whether that is by interacting with intracellular proteins or via its action on 5 G-protein coupled cell membrane receptors. Following transient global cerebral ischemia (tGCI), the CA1 sub-region of the hippocampus undergoes apoptosis, while other areas do not. In this work we evaluated S1P levels as well as S1P expression in different hippocampal areas (CA1 and CA3) following tGCI in rats. We found that S1P is upregulated early in CA3 as compared with CA1, this was associated with upregulation of SphK1 in both regions but SphK2, which has a pro-apoptotic motif, was downregulated quickly in CA3. S1P lyase (Sgpl1) was also downregulated in CA3 in contrast to CA1. Spinster 2, the S1P exporter, was upregulated early in both region, but in CA3 it was quickly and extremely downregulated. These effects combined explain the variable levels of S1P in CA1 and CA3 and demonstrate that S1P levels play a role in the preferential resistance of $\mathrm{CA} 3$ sub-region to $\mathrm{tGCI}$ induced ischemia. 


\section{虚血再灌流による脳皮質でのペントース リン酸経路賦活化の意義－Heat shock protein 27リン酸化の役割一}

\author{
${ }^{1}$ 神戸大学大学院 医学研究科 脳神経外科学分野、 \\ ${ }^{2}$ 公立豊岡病院 脳神経外科、 ${ }^{3}$ 神戸大学大学院 医 \\ 学研究科 立証検査医学分野、 ${ }^{4}$ 神戸大学大学院 医 \\ 学研究科 地域社会医学・健康科学講座 疫学分野 \\ 質量分析総合センター \\ ○松尾 和哉 ${ }^{1}$ 、細田 弘吉 ${ }^{1} 、$ 田中 潤 ${ }^{1}$ 、 \\ 山本 祐輔 ${ }^{1} 、 今$ 今堀太一郎 ${ }^{2}$ 、中井 友昭 ${ }^{1} 、$ \\ 入野 康宏 $^{3}$ 、篠原 正和 ${ }^{4}$ 、甲村 英二 $^{1}$
}

【緒言】脳虚血再灌流障害の病態生理を解明する為、メ夕 ボローム解析により包括的代謝変化を調べた。

【方法】糸栓子による中大脎動脈閉塞モデルラットで虚血 再灌流群 ( 1 時間虚血 $+0 、 1 、 3 、 5 、 24$ 時間再灌流 ; $n=6$ / 群) と対照群を作製して脳皮質を採取し、Gas Chromatograph-Mass Spectrometry (GC-MS)でメタボローム解析 を行った。虚血と関連する代謝物と関連経路については さらにPCRやImmunoblot (IB)などを行った。

【結果】GC-MSにより96代謝物が同定され、多変量解析 で再灌流時間に依存する代謝変化が認められた。この変 化に寄与する16代謝物を用いてエンリッチメント解析を 行うとペントースリン酸経路(PPP)が最も光進していた。 個々の代謝物の評価でもPPPに属する Fructose 6-phosphate、Ribulose 5-phosphateが増加し、再灌流下でのPPP 充進が示唆された。我々が以前に報告した虚血のみの実 験結果から、PPPに扔いてAtaxia telangiectasia mutated kinase (ATMK)によるHeat shock protein 27 (HSP27)の リン酸化が、Glucose 6-phosphate dehydrogenase (G6PD) を活性化する事が判明した為、PPPをさらに精査した。 G6PDはmRNA、蛋白ともに有意変化はなかったが、RTPCRでHSP27 mRNAは虚血再灌流24時間後に69倍まで 増加した。IBではHSP27蛋白の増加は軽度であったが、 そのリン酸化は 24 時間後に 4.5 倍に増加した。G 6 PD活性 も24時間後に有意に約 $20 \%$ 上昇した。また、G6PDが生 成するNADPHも虚血再灌流24時間後に有意に4.4倍ま で増加した。さらに、ATMK阻害薬の脳室内投与により、 脳梗塞サイズ (大脳半球に占める体積割合) は対照群より も有意に増大した ( $16 \%$ vs $34 \% ： \mathrm{p}<0.001 ; \mathrm{n}=6$ /群)。

【結論】虚血再灌流後も少なくとも 24 時間は脎虚血超急性 期と同様に、PPPにおいてATMKによるHSP27のリン酸 化でG6PDが活性化され、NADPHが増加することでグル タチオン再還元による抗酸化能を維持する機構が示され た。この機構は新たな治療ターゲットとなり得る。

\section{マウス脳虚血・再灌流負荷時のNO, OH- 代謝に対する抑肝散の影響}

${ }^{1}$ 埼玉医科大学 医学部 神経内科、 ${ }^{2}$ 東松山医師会 病院

○北林 知佳 $^{1} 、 川$ 崎 一史 ${ }^{1}$ 、平山真紀子 ${ }^{1}$ 、 西岡 亮治 ${ }^{1}$ 、山里 将瑞 ${ }^{2}$ 、伊藤 康男 $^{1}$ 、 高橋 一司 ${ }^{1}$ 、山元 敏正 $^{1}$ 、荒木 信夫 $^{1}$

【背景】抑肝散は大脳皮質のアストロサイトへのグル 夕ミン酸の取り込みを是正し細胞外液中のグルタミ ン酸の上昇を抑える作用などにより、神経細胞の過 剩興奮を抑制していると考えられている。

【目的】抑肝散の神経保護作用の機序を検討するため、 マウス脳虚血・再灌流負荷時のNO、OH-代謝及び 脳虚血性変化に関する抑肝散の作用を検討した。

【方法】抑肝散 $(300 \mathrm{mg} / \mathrm{kg} / \mathrm{day})$ を 10 日間経口投与し た抑肝散群 $(\mathrm{n}=7)$ と非投与群 $(\mathrm{n}=8)$ としてC57BL/6 マウスを用いて検討した。一側大腿動脈にカテーテ ルを挿入し血圧を測定した。左線条体に微小透析プ ローブを刺入しin vivo microdialysisを施行、10分 毎に灌流液を回収した。NO2-とNO3-濃度はGriess 反応で測定した。同様に右線条体に微小透析プロー ブを刺入しin vivo microdialysisを施行し20分每に 灌流液を回収した。OH-はサリチル酸をトラップし 2,3DHBA及び2,5DHBA濃度として測定した。右側 の頭蓋骨上にレーザードップラー血流計プローブ を設置し脳血流を測定した。マウス脳虚血モデル は両側総䅡動脈を clippingした10分間の前脳虚血負 荷後、再灌流を行った。虚血性変化の検討のため、 C57BL/6マウス $(n=12)$ に虚血・再灌流負荷を行い、 再灌流 72 時間後に脳を摘出しブアン固定液にて固 定後HE染色及び8-OHdGを行い細胞の海馬CA1 領 域のsurvival rateを算出した。

【結果】 MABP : 有意差はなかった。\% $\mathrm{CBF}$ ：再灌流 後20-70分の間で抑肝散群 $(50.6 \pm 12.0 \%)$ が非投与 群 $(64.9 \pm 13.6)$ と比べ有意に低值であった $(\mathrm{p}<0.05)$ 。 total NO濃度 : 再灌流後50-60、120 分で抑肝散群 (5.9 $\pm 1.3)$ が非投与群 $(4.4 \pm 1.4)$ と比べ有意に高值で あった。 total DHBA濃度 : 再灌流時、再灌流後 100 分で抑肝散群 $(90.2 \pm 8.1)$ が非投与群 $(107.7 \pm 15.0)$ と比べ有意に低值であった。Survival rate (HE染 色）：有意差はなかった。Survival rate (8-OHdG)： 有意差はなかった。 


\section{Exendin-4投与下におけるマウス前脳虚 血・再灌流負荷時のNOとOH-代謝への影 響}

${ }^{1}$ 埼玉医科大学病院 神経内科、 ${ }^{2}$ 東松山医師会病院

$$
\begin{aligned}
& \bigcirc \text { 川崎 一史 }{ }^{1} \text { 、北林 } \text { 知佳 }^{1} \text { 、伊藤 康男 }{ }^{1} \text { 、 } \\
& \text { 山里 将瑞 }{ }^{2} \text { 、西岡 亮治 }{ }^{1} \text { 、高橋 一司 }{ }^{1} \text { 、 } \\
& \text { 山元 } \text { 敏正 }^{1} \text { 、荒木 } \text { 信夫 }^{1}
\end{aligned}
$$

【目的】GLP-1作動薬であるExendin-4は、血糖依存 性にインスリン分泌促進作用を有する合成ペプチ ドであり、糖尿病治療薬として臨床応用されてい る。近年Exendin-4が脳虚血に対して、脳保護作用 を有することが明らかになってきた。昨年、我々は Exendin-4投与下におけるマウス前脳虚血・再灌流 負荷時の $\mathrm{NO}$ と $\mathrm{OH}$-代謝への影響を検討したが、有 意な結果が得られなかった。今回Exendin-4の投与 量を増量し、同様の検討をした。

【方法】雄性C57BL/6マウスを用い、虚血30分前に Exendin-4 (500 $\mu \mathrm{g} / \mathrm{kg}$ i.p.)を投与した群 (pre-E群、 $\mathrm{n}=5$ ) と非投与群 (Cont群、 $\mathrm{n}=9$ ) で検討した。左大 脳線条体に微小透析プローブを刺入しin vivo microdialysisを施行し、NO2-とNO3-濃度をGriess 反 応で測定した。右線条体にも同様にin vivo microdialysisを施行し、OH-をサリチル酸でトラップした 2,3DHBA、2,5DHBA濃度として測定した。頭盖骨 表面からレーザードップラー血流計で脳血流を測定 した。血圧は左鼠径動脈にカテーテルを挿入し、観 血的に測定した。両側総頸動脈をクリッピングし、 10 分間の前脳虚血とした。

【結果】血圧：両群間に有意差はなかった。脳血流： 両群間に有意差はなかった。\% $\mathrm{NO2}$-濃度 : 再灌流後 20 分で、pre-E群 $(79.2 \pm 19.3 \%$; mean \pm SD $)$ がCont 群 $(106.5 \% \pm 33.4 \%)$ に比し有意に低值であった。 \% NO3-濃度：両群間に有意差はなかった。総DHBA 濃度 $(2,3 \mathrm{DHBA}$ 濃度 $+2,5 \mathrm{DHBA}$ 濃度)：再灌流後は、 pre-E群がCont群に比し低值であったが、有意差は なかった。

【結論】総OH-産生は、脳虚血再灌流後は、pre-E群 がCont群に比し低值であったが、統計学的な有意差 は得られなかった。今回Exendin-4の投与量を、昨 年の10倍に増量して検討したが、Exendin-4の脳保 護作用は明かとはならなかった。

\section{ヘモグロビン-アルブミン複合体による脳 虚血再灌流急性期治療}

${ }^{1}$ 北海道大学 医学部 脳神経外科、 ${ }^{2}$ 中央大学理工 学部 応用化学科、 ${ }^{3}$ 手稲溪仁会病院 脳神経外科

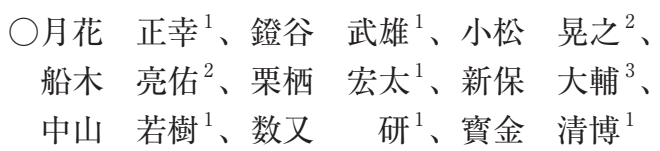

【背景】へモグロビン-アルブミン複合体であるHemo$A c t^{\mathrm{TM}}$ は(1)微細粒子による良好な微小循環酸素運搬能 (2) アルブミンによる抗酸化作用及び循環血漿量増加 作用が期待され、脳虚血再灌流障害(I/R injury)にお いて脳保護効果を発揮するかが注目される。 【目的】ラット一過性中大脳動脈閉塞モデル ( $\mathrm{tMCAO})$ にて、再灌流時にHemoActを再開通動脈より灌流し、 I/R injuryに対する脳保護効果、微小循環における $\mathrm{He}-$ moActの灌流状況と効果・酸素運搬能を検討した。

【対象・方法】雄SDラットで糸栓子による $\mathrm{tMCAO}(2 \mathrm{~h}$ 虚血)を行い、Control (c) 群、PBS 灌流 (V) 群、50\% HemoAct灌流 $(50 \% \mathrm{H})$ 群、HemoAct灌流 $(\mathrm{H})$ 群の4群 を作成した。再灌流24h後のラットにて18 point scale で神経症状を評価、TTC染色で脳梗塞体積、Western blotting でMMP-9 発現、活性酸素産生(4-HNE) を検討 した。再灌流 0,2 , 6 h後のラットで、微小血管の経時的 変化 (vWFの免疫染色で評価)、微小血管内に㧍ける HemoActの局在(ヒトアルブミン抗体及びラットへモ グロビン抗体による免疫染色で評価)、脳組織酸素分 圧の継時的変化(酸素電極刺入型の組織酸素分圧測定 装置による評価)を検討した。またin vivoで、ラット 脳血管内皮細胞の低酸素再酸素化モデルを作成し、各 薬剤投与時の酸化ストレスを検討した。

【結果】神経症状は $H$ 群で他 3 群に対し有意に軽かっ た。脳梗塞体積は、C群 $55.2 \%$ 、V群 $53.2 \%$ 、 $50 \% \mathrm{H}$ 群 27.1\%、H群 : 20.2\%で、H群でC群、V群に対し有意に 小さかった。MMP-9発現、活性酸素産生もH群で有意 に抑制された、また、再灌流6h時点で見られる微小血 管狭小化がH群で抑制され、微小血管でHemoActがよ り多く灌流しているのが確認された。HemoAct2 時間 後及び6 時間後の微小血管内でのHemoActの局在が確 認でき、虚血再灌流側の脳組織酸素分圧の改善を認め た。低酸素再酸素化されたラット脳血管内皮細胞にお いて、HemoAct投与時の酸化ストレスの抑制を認めた。 【結論】HemoActは、再灌流後の微小循環において良 好な灌流状態を作り出し、I/R injuryに対し非常に強 い脳保護効果を発揮した。 


\section{Pretreatment Effects with Rivarox- aban on NVU Dissociation after Thrombolysis in Ischemic Rat Brain}

\author{
岡山大学病院 脳神経内科
}

\author{
○商敬偉、山下 徹、中野由美子、 \\ 太田 康之、阿部 康二
}

【BACKGROUND】 Warfarin and rivaroxaban are highly effective in reducing stroke risk in patients with atrial fibrillation $(\mathrm{AF})$. However, their effects on neurovascular unit (NVU) change remain elusive. Here, we assessed the risks and benefits of pre-treatment with warfarin or rivaroxaban after tPA thrombolysis in ischemic rat brain.

【METHODS】 Pre-treatment with warfarin $(.2 \mathrm{mg}$ / $\mathrm{kg}$ /day), low dose rivaroxaban $(60 \mathrm{mg} / \mathrm{kg} /$ day $)$, high dose rivaroxaban $(120 \mathrm{mg} / \mathrm{kg} /$ day $)$ or vehicle was performed for 2 weeks, tMCAO was induced for $90 \mathrm{~min}$, then followed by reperfusion with tPA. At 24 hours (h) after reperfusion, we observed the changes of matrix metalloproteinase-9 (MMP-9), tissue factor, caspase 3 and NVU dissociation.

【RESULTS】 MMP-9 expression greatly increased in the warfarin group, and this was reduced in the rivaroxaban groups compared with the vehicle group. Tissue factor expression remarkably decreased in the warfarin and rivaroxaban groups. The number of caspase 3-positive cells had no difference among all the groups. Marked dissociations between astrocyte foot processes and the basal lamina or pericytes were observed in the warfarin pretreated group, but such dissociations were improved in the rivaroxaban groups.

【CONCLUSIONS】 Our present study shows that pre-treatment with rivaroxaban was noninferior to warfarin in the anticoagulation, but a lower risk of NVU dysfunction and dissociation after tPA treatment in rivaroxaban. This finding could partly explain the mechanism of reducing hemorrhagic complications by rivaroxaban in clinical studies.

\section{マウス慢性脳虚血モデル初期のBBB破綻 に対する酸化ストレス抑制効果の検討}

${ }^{1}$ 順天堂大学医学部付属順天堂医院 脳神経内科、

${ }^{2}$ Neuroprotection Research Lab、Department of Radiology、Massachusetts General Hosp and Harvard Medical School、 ${ }^{3}$ 順天堂大学医学部付属 浦安病院 脳神経内科

$\bigcirc$ 宮元 伸和 ${ }^{1} 、$ Pham Loc-Duyen D. ${ }^{2}$ 、

眞木 崇州 ${ }^{2}$ 、田中 亮太 ${ }^{1}$ 、下部 貴夫 $^{3}$ 、

Lo Eng H. ${ }^{2}$ 、荒井 健 $^{2}$ 、服部 信孝 ${ }^{1}$

【目的】脳白質は脂質系が豊富な場所であり、容易に 酸化ストレスが上昇する。慢性脳虚血モデルにおい てもごく初期に血液脳関門の破綻が起こり、酸化 ストレスが関与することを我々は過去に報告した。 Edaravoneは酸化ストレス抑制薬として脳梗塞急性 期の加療に使用されているが、上記病態に関しての 有用性は示されていない。今回我々は慢性脳虚血後 極初期の病態に対して酸化ストレスを抑制すること により血液脳関門 (BBB) 破綻が防げるかを検討した。 【方法】10-12 週令 8 週齢雄性 C57BL/6 用い両側 総頸動脈狭窄をもちいた慢性脳虚血モデルを作成 (BCAS)。Edarabone投与群 $(3 \mathrm{mg} / \mathrm{kg}$ ip、day0,3に て投与) と vehicle群 (各n=15)に分け、免疫組織化学 的評価を行った。さらにはC CoCl2を用いたラットオ リゴデンドロサイト初代培養系も用い検討を行った。 【成績】 BBB破綻をIgG染色にて評価したところ、 手術後7日目においてvehicle群では染色範囲の拡 大をsham群に比し認めたが、Ederabone投与群に おいては有意に抑制をしていた $(\mathrm{p}<0.05)$ 。同様に MMP9染色においてもvehicle群ではsham群に比し 有意に染色範囲の拡大を認めたが、Edaeabone群 では有意に抑制を認めた $(\mathrm{p}<0.05)$ 。MMP9は手術 後3日目においてはオリゴデンドロサイト前駆細胞 (OPC) から発現していたが、手術後7日目において はOPCと血管内皮細胞に認めていた。そのためラッ 卜初代培養系においてOPCに慢性虚血負荷を与えた とろ、MMP9が出現し、この現象はedearbone投与 により有意に減少した $(\mathrm{p}<0.05)$ 。

【結論】以上の結果から、酸化ストレスを抑制するこ とにより慢性脳虚血極初期の血液脳関門破綻が保護 される可能性がしさされ、今後の治療の一手となる 可能性が示唆された。 


\section{Xa阻害薬 rivaroxaban の PARを介した tPA後の頭蓋内出血抑制効果}

岡山大学病院 神経内科

○森原 隆太、山下 徹、河野祥一郎、 商敬偉、中野由美子、阿部 康二

【背景と目的】tPAによる血栓溶解療法は脳梗塞発 症後 4.5 時間以内に使用した場合に改善効果を示し うるが、NOAC内服中に発症した脳梗塞に対する血 栓溶解療法の適応基準は明確なものはない。そこで 今回、warfarinもしくはrivaroxabanを内服させた ラット脳梗塞モデルに対してtPA投与を行い、出血 性脳梗塞への関与について検証する。

【方法】11週齢のオスのwistarラットをvehicle群、 warfarin投与群、rivaroxaban投与群(低用量群と高 用量群)の 4 群に分け14 日間投与後、90分の一過性 脳虚血を負荷し、再灌流時に tPAを投与する。再 灌流 24 時間後に断頭し脳を摘出する。

【結果】vehicle群に比べてPT（プロトロンビン時 間)はwarfarin群と rivaroxaban群にて有意に延長し、 TAT (トロンビン・アンチトロンビン複合体 ) は warfarin群と rivaroxaban群で有意に低下していた。 脳梗塞体積は各群で差はなかったが、脳出血体積 はwarfarin群で増加しており、この増加はrivaroxaban群では認められなかった。免疫組織学的検討で は、warfarin群で梗塞周囲においてPAR-1、2 陽性 の細胞が増加していたが、rivaroxaban群ではその 増加が認められなかった。warfarin群では梗塞巣周 囲のMMP-9活性が立進するとともにneurovascular unitが解離していたが、rivaroxaban群ではMMP-9 立進やneurovascular unitの解離が認められなかっ た。

【結論】warfarin群でのtPA投与後の出血の増加は rivaroxaban群では認められなかった。warfarin群 では何らかの機序によりPAR-1、2が立進すること でその下流のMMP-9が光進し、これが細胞外マト リックスを分解することでneurovascular unitを壊 して出血をもたらしていた可能性がある。一方 Xa 阻害剤である rivaroxabanはPARを抑制することで これらの変化を防ぐことができた可能性があると考 えられた。

\section{ラット中大脳動眽閉塞モデルにおけるグ リベンクラミドの出血性変化への効果}

${ }^{1}$ 日本大学医学部 脳神経外科学系 神経外科学分 野、 ${ }^{2}$ マサチューセッツ総合病院 神経内科 神経集 中治療部門

○五十嵐崇浩 ${ }^{1,2}$ 、Sastre Cristina ${ }^{2}$ 、

Kimberly T William ${ }^{2}$ 、吉野 篤緒 ${ }^{1}$

【背景】急性期脳梗塞治療は、血栓溶解療法に加えて 機械的血栓除去術の普及により血流再開の可能性を 高める事ができた。一方で、脳虚血・再灌流後の二 次性変化である出血が患者の予後に大きな影響を及 ぼす事が知られている。近年、脳梗塞治療において スルホニルウレア受容体1(SUR1)の存在が注目さ れている。SUR1は、虚血早期より発現し細胞毒性 浮腫を引き起こす事が知られており、グリベンクラ ミドはSUR1に対する強力な阻害作用を有している。 本研究では再灌流後の出血性変化に対するグリベン クラミドの効果を検証した。

【方法】Wistarラットを用い、3 時間中大脳動脈フィ ラメント閉塞モデルを作成した。再灌流後に薬剤溶 出ボンプを皮下に植え込み、対照群とグリベンクラ ミド群に分けた。再灌流直後と 48 時間後に神経機 能評価を行った。48時間後に脳を摘出し、梗塞体積、 組織水分量、組織内へモグロビン $(\mathrm{Hb})$ 量を計測し た。マトリックスメタロプロテアーゼ (MMP) と出 血性梗塞の程度に相関関係がある事が報告されてい る事から血清中のMMP9の測定を行った。IgG免疫 染色を行い血液脳関門の状況を評価した。

【結果】虚血性変化 : グリベンクラミドによる梗塞体 積の縮小、脳浮腫の軽減を認め、両群間で統計学 的有意差を認めた。出血性変化：グリベンクラミド 群で組織内 $\mathrm{Hb}$ 量が対照群と比べても少なく両群間 で統計学的有意差を認めた。血清MMP9はグリベ ンクラミド群の方が対照群に比べて低い值を示し、 MMP9 と組織内 $\mathrm{Hb}$ 量には相関関係を認めた。 IgG免 疫染色ではグリベンクラミド群でIgGの血管外漏出 が抑制されている所見を認めた。

【結語】今回、グリベンクラミドの梗塞体積縮小、脳 浮腫の軽減に加えて、出血性変化の抑制効果を確認 できた。また、高速液体クロマトグラフィーで測定 した血清中のグリベンクラミド濃度とMMP9の間に は逆相関を認め、グリベンクラミドによる MMP9 抑制が出血性変化に寄与していることが示唆された。 


\section{マウス脳出血に対するNrf2 活性化薬の作 用}

${ }^{1}$ 岐阜薬科大学 薬効解析学、 ${ }^{2}$ 岐阜大学 医学部 脳 神経外科

\begin{tabular}{|c|c|c|}
\hline ○杉山 & 智紀 ${ }^{1}$ 、山内 & 圭太 ${ }^{1,2}$ 、澤田 重信 $^{1,2}$ 、 \\
\hline 今井 & 貴彦 ${ }^{1} 、$ 岩田 & 星菜 ${ }^{1}$ 、嶋澤 雅光 ${ }^{1}$ 、 \\
\hline 岩間 & 亨 ${ }^{2} 、$ 原 & 英彰 ${ }^{1}$ \\
\hline
\end{tabular}

【背景・目的】脳出血発症後に組織へ漏出した血液は、 神経やグリアに障害を誘発し、予後を増悪させるこ とが報告されている。血液成分のうちへモグロビン は組織においてへム及びへミンへ代謝し、その後活 性酸素種 (reactive oxygen species：ROS)を惹起す ることで細胞障害の一因となることが知られている。 元来、生体内には酸化ストレス応答因子が存在して おり、転写因子であるNrf2は酸化ストレスにより通 常条件下で結合しているKeap1と解離し、核内へ移 行する。その後、下流シグナルであるHeme Oxygenase 1 (HO-1) 等の抗酸化酵素を誘導し、ROSの 消去により酸化ストレスに対する防御機構として働 いている。今回、Nrf2 経路の活性化の脳出血に対 する効果について検討するため、Nrf2 活性化薬RS9 を用いて脳出血後二次性脳障害に対する作用の検討 を行った。

【方法】In vivoにおいて、12週齢雄性ddYマウスを 用い、頸静脈より採取した自家血 $(25 \mu \mathrm{L})$ をハミル トンシリンジを用いてマウス左脳線条体に定位注 入した。処置 $0 、 24$ 及び48時間後にRS9 $(0.2 \mathrm{mg} / \mathrm{kg}$ 、 第一三共株式会社より供与)を腹腔内投与した。投 与 72 時間後の脳水分量と神経所見の評価を行った。 また、ウエスタンブロット法を用いて出血周囲の夕 ンパク質発現量の検討を行った。In vitroにおいて、 神経芽細胞を用いてへミン障害に対する作用を検討 するため、細胞死評価及びROS assayを行った。

【結果】In vivoにおいて、RS9は72時間後の血腫周 囲の水分量の上昇を抑制し、行動試験における上肢 行動不全の改善が認められた。また血腫周囲におい てHO-1の経時的な発現上昇が認められた。RS9は、 in vitroにおいてへミン誘発性細胞死及びROS産生 を抑制した。

【結論】RS9はNrf2 経路の活性化に伴うHO-1の発現 上昇により、脳出血後の浮腫及び神経症状を改善し た。このことからRS9は脳出血後の二次的脳障害に 対して保護作用を示すことが示唆された。

\section{一過性中大脳動眽閉塞モデルにおける慢 性低潅流負荷の効果}

東京女子医科大学 神経内科

○齋藤 萌子、石塚健太郎、北川一夫

【目的】一側総頸動脈閉塞による慢性低潅流負荷の一 過性中大脳動脈閉塞に対する効果を神経症状、梗塞 体積、側副血行発達程度、MRIDWI病変体積より 検証する。

【方法】成熟C57BL6マウスを用いてイソフルレン吸 入麻酔下で左総頸動脈を露出、結紮し、3、5、7ま たは 14 日後に7-0ナイロン糸を挿入し45分間左中大 脳動脈 $(\mathrm{MCA})$ を閉塞後再灌流した。24時間後に神 経症状を観察し脳を摘出後TTC染色で脳梗塞体積 を算出した。神経症状は既報に基づき0（症状なし） から5 (死亡)の6段階で評価した。MCA閉塞再灌流 中の脳皮質血流をモニターした。対照群は前処置な しにMCAを閉塞再灌流した群(対照群)および左総 頸動脈を露出するだけの偽手術 14 日後にMCAを閉 塞再灌流した群 (偽手術群) とした。偽手術群および 慢性低潅流 14 日群については以下の実験を追加し た。MCA閉塞45分後に墨汁とラテックス混和液を 左心室より注入し脳軟膜吻合血管径を計測した。小 動物用MRIを用いて再灌流直後のADCmapより信 号低下を示す体積を算出した。

【結果】各群の残存血流は対照群、偽手術群、3 日 前、5 日前、7 日前、14日前群において $20 \% 、 24 \%$ 、 $32 \% 、 27 \% 、 34 \% 、 46 \%$ で対照群に対し7日、14日 前群で有意に増加していた。24時間後の神経症状 は中央值が2、2、2、2.5、1、0で対照群に対し7日、 14 日前群で有意に良好であった。梗塞体積は $57.9 \pm$ $10.3 \mathrm{~mm}^{3} 、 54.1 \pm 8.6 \mathrm{~mm}^{3} 、 57.3 \pm 20.1 \mathrm{~mm}^{3} 、 54.8 \pm$ $10.4 \mathrm{~mm}^{3} 、 18.9 \pm 15.4 \mathrm{~mm}^{3} 、 4.9 \pm 2.7 \mathrm{~mm}^{3}$ で対照群に 対し7 日、14 日前群で有意に縮小していた。脳軟膜 吻合血管径は偽手術群 $25.0 \pm 2.2 \mu \mathrm{m}$ に対し14 日前群 $35.5 \pm 5.5 \mu \mathrm{m}$ で有意に拡大していた。ADCmap体積 でも $55.1 \pm 11.4 \mathrm{~mm}^{3} 、 5.8 \pm 1.9 \mathrm{~mm}^{3}$ で 14 日前群で有 意に縮小していた。

【結論】マウス一過性中大脳動脈閉塞モデルにおいて 7 日前または14 日前から慢性低潅流状態を負荷する ことにより脳保護効果が観察された。 


\section{ラット脳梗塞巣におけるIL-3とGM-CSF 混合皮下投与の有効性の検討}

1 愛媛大学大学院 医学系研究科 脳神経外科学、 2 愛媛大学大学院 医学系研究科 地域医療再生学、3 愛媛大学大学院 医学系研究科 分子細胞生理学

$\bigcirc$ 松本 調 ${ }^{1}$ 、久門 良明 ${ }^{2}$ 、渡邊 英昭 ${ }^{1}$ 、

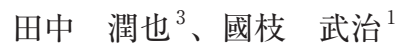

ラット中大脳動脈一過性閉塞による脳梗塞モデルの 梗塞中心部に、骨髄由来のマクロファージが高密 度に集積する。それらの多くがマクロファージの マーカーのIbalとNG2コンドロイチン硫酸プロテオ グリカン (NG2) 陽性であることから、これらの細胞 をBINCs (Brain Iba1+/NG2+ Cells) と呼んでいる。 BINCsは脳梗塞発症後にケモカイン依存的に脳実質 に侵入する単球に由来し、神経保護因子を分泌する ことによって、梗塞による組織障害を改善させる。 しかし、高齢脳梗塞症例の梗塞中心部では、BINCs の集積はごくわずかであり、高齢ヒト脳梗塞の機 能的予後不良に関連すると考えられる。これは、高 齢者の骨髄は反応性にそしく、十分なBINCs前駆細 胞の動員ができないためと想像される。そこで、顆 粒球・単球前駆細胞を特異的に刺激するGM-CSFと 造血幹細胞の増殖 ・ 分化や活性化など幅広い作用を 示すIL-3を混合投与することにより、骨髄を刺激し、 BINCsの梗塞巣への集積を高めることを考えた。ま た、これらのサイトカインは抗アポトーシス因子の Bcl-xL発現を増大させるなどにより、神経細胞に対 して直接的な保護作用を示すこと、さらに、血液脳 関門を超えて脳実質に入りうることも示されている。 本研究では、ラット脳梗塞モデルに対して、IL-3と GM-CSFを虚血負荷翌日より1日1回5日間皮下注射 し、その治療効果を検討した。3か月のフォローで、 IL-3 と GM-CSFの混合投与群は、MRIで計測される 脳梗塞巣の容積を減少させ、水迷路試験により測 定される学習行動を改善させた。現在、IL-3とGMCSFによる脳梗塞の縮小効果や機能的改善効果のメ カニズムについての解析を行っている。

\section{mRNAデリバリーによる虚血性神経細胞 死治療-Enhancement of neuroprotec- tive effect of astrocytes-}

\author{
${ }^{1}$ 東京大学 医学部附属病院 脳神経外科、 ${ }^{2} 川$ 崎市 \\ 産業振興財団 ナノ医療イノベーションセンター、 \\ ${ }^{3}$ 東京大学 大学院工学系研究科 マテリアル工学専 \\ 攻、 ${ }^{4}$ 東京医科歯科大学 生体材料工学研究所
}
$\bigcirc$ 福島 雄大 ${ }^{1}$ 、今井 英明 ${ }^{1}$ 、内田 智士 ${ }^{2,3}$ 、 中冨 浩文 ${ }^{1}$ 、片岡 一則 ${ }^{2}$ 、位高 啓史 ${ }^{4}$ 、 斉藤 延人 ${ }^{1}$

【背景】虚血障害に対する神経保護研究は長く行われ てきたが、世界的に普及する薬剤は存在しない。脳 由来神経栄養因子 $(\mathrm{BDNF})$ に代表される生体由来夕 ンパクは基礎実験で多くの神経保護効果を証明して きたが、一方で中枢神経系への有効な deliveryに大 きな問題がある。そこで近年注目を集めるナノミセ ル技術を用いたmRNA deliveryに着目した。BDNF mRNAを投与することで持続的なBDNF産生が中枢 神経系の細胞内で行われ、薬剤deliveryの問題を克 服する画期的な薬剤となるのではないか。

【方法】レポータータンパク発現mRNAによる動態 評価を踏まえ、ラット一過性前脳虚血モデルに対し BDNF mRNAを生体適合性ナノミセルに内包し、虚 血後種々のタイミングで側脳室内投与した。組織切 片のNeuN免疫染色にて神経細胞の生存割合を定量 した。また、神経系マーカーとBDNFとの二重染色 により、BDNFを発現する細胞を同定した。

【結果】ナノミセルを用いた mRNA側脳室内投与に より 2 日間以上の持続的タンパク質産生が得られた。 ラット前脳虚血モデルに対しBDNF mRNAを虚血後 種々のタイミングで単回投与し6日目の脳切片で評 価したところ、BDNF mRNAを虚血後2 日目に投与 した群で50\%以上の細胞生存を認め、これは虚血直 後を含む他のタイミングより優れていた。免疫二重 染色の結果、アストロサイトが特異的にBDNFを発 現している所見が得られた。

【結論】mRNAによるBDNF導入は中枢神経系の薬剤 送達の困難さを克服する神経保護薬として有望であ る。一般的にアストロサイトは恒常性維持機能によ り薬剤排泄に関わるが、mRNAであればむしろ治療 タンパク産生拠点として働きうる可能性が示された 点は画期的と言える。更に慢性期での治療効果を脳 切片・短期記憶行動評価の結果と併せて報告する。 


\section{脳血管障害に対するアドニキサンチンの 保護作用}

${ }^{1}$ 岐阜薬科大学 薬効解析学研究室、 ${ }^{2} \mathrm{JXTG}$ エネル
ギー株式会社

○岩田 星菜、今井 貴彦 ${ }^{1}$ 、杉山 智紀 ${ }^{1}$ 、 嶋澤 雅光 ${ }^{1}$ 、石橋 卓 ${ }^{2}$ 、原 英彰 ${ }^{1}$

【背景・目的】脳血管障害後の組織障害に対して抗酸 化作用を有する化合物が効果を示すことが報告され ている。アスタキサンチンは、高い抗酸化作用を有 する物質として化粧品やサプリメントに用いられる カロテノイドの一種であり、血液脳関門を通過でき ることから脳保護作用にも注目が集まっている。そ のため、種々の脳血管障害に対して保護作用を示す と考えられる。実際に、過去の報告においても脳梗 塞やクモ膜下出血で有効性が示されている。アドニ キサンチンはアスタキサンチン合成における中間生 成物であり、アスタキサンチン同様またはそれ以上 の抗酸化作用を有することが報告されている。そこ で我々は、in vitroに扔ける種々の脳血管障害に及 ぼすアドニキサンチンの影響について検討した。

【方法】ヒト脳毛細血管内皮細胞 (Human brain microvascular endothelial cells; HBMVECs）を用い て検討を行った。15,000cells / cm2で播種した細胞が コンフルエントになった後、アドニキサンチンを 24 時間前処置し、その後、コラゲナーゼ、へモグロビン、 lipopolysaccharide (LPS) 等の障害を誘導し、細胞 死評価やWestern blot法によるタンパク質発現量へ の影響を評価した。

【結果】HBMVECsにおいてアドニキサンチンは、 コラゲナーゼ障害による細胞死を抑制し、リン酸 化Extracellular signal-regulated kinase (ERK)の上 昇の抑制、リン酸化Aktの減少抑制を示した。また、 細胞間結合であるVascular endothelial (VE)-cadherin の減少を抑制した。さらにへモグロビン処置により 誘発された細胞死も同様に抑制した。

【結論】アドニキサンチンは、各種脳障害に対して生 存シグナルの抑制の改善や細胞間結合の減少抑制を 介して保護的に働くことが示唆され、脳出血に対し てもカロテノイド、特にアドニキサンチンは有効性 が高い可能性が考えられる。

\section{腸内細菌叢の異常に伴う高LPS血症は急性 期脳梗塞の組織障害進展に関与する}

${ }^{1}$ 順天堂大学 医学部 脳神経内科、 ${ }^{2}$ 順天堂大学浦 安病院 脳神経内科、 ${ }^{3}$ 順天堂大学大学院プロバイ オティクス研究講座、 ${ }^{4}$ 株式会社ヤクルト本社中央 研究所

$\bigcirc$ 栗田 尚英 ${ }^{1}$ 、山城 一雄 ${ }^{1}$ 、黑木 卓馬 ${ }^{1}$ 、 田中 亮太 ${ }^{1}$ 、上野 祐司 ${ }^{1}$ 、卜部 貴夫 ${ }^{2}$ 、 山城雄一郎 ${ }^{3} 、$ 野本 康二 ${ }^{3}$ 、松本 敬 ${ }^{3,4}$ 、 高橋 环也 ${ }^{3,4}$ 、辻浩和 ${ }^{3,4}$ 、朝原崇 ${ }^{3,4}$ 、 服部 信孝 ${ }^{1}$

【目的】腸内細菌丵は宿主の健康および疾患と密接に 関連している。腸内細菌叢が急性期脳梗塞に与える 影響とその機序について解析を行った。

【方法】12週齢の糖尿病マウス $(\mathrm{db} / \mathrm{db})$ と正常対照 $(\mathrm{db} /+)$ を用いて以下の解析を㧍こなった。1)16S扔 よび23S rRNAをターゲットとした定量的RT-PCR 法による腸内細菌叢解析、2) 血糖値㧍よび血中LPS (lipopolysaccharide) 濃度測定、3）FITCラベルし たデキストランを経口投与後に採血し、血中FITC 蛍光強度を測定し腸管透過性を評価、4)一過性中大 脳動脈閉塞 $(\mathrm{MCAO})$ による脳梗塞を作成し、24時 間後に運動機能障害と脳梗塞組織を評価。

【結果】 $\mathrm{db} /+$ と比較して $\mathrm{db} / \mathrm{db}$ では、糞便中のグラ ム陰性桿菌Enterobacteriaceae菌数、血中でグラム 陰性桿菌細胞膜構成成分のLPS濃度が有意に上昇し、 腸管透過性が有意に立進していた。非吸収性抗生物 質ポリミキシン Bを経口投与した $\mathrm{db} / \mathrm{db}$ では、穓便 中のEnterobacteriaceae菌数、血中LPS濃度、腸管 透過性が有意に減少した。血糖値に有意差は認めな かった。MCAO施行後では db/+と比較して $\mathrm{db} / \mathrm{db}$ では、運動機能障害、脳梗塞体積、脳梗塞巣周囲ミ クログリア数、血液脳関門の透過性、MMP (matrix metalloproteinase) 9 の発現が有意に増加し、LPS レセプターであるTLR (toll-like receptor) 4 と interleukin $1 \beta$ 、interleukin 6 の発現が有意に上昇したが、 ポリミキシンBの投与はこれらを有意に減少させた。 【結論】腸内細菌叢の異常に伴う高LPS血症は、炎症 を介して急性期脳梗塞の組織障害進展に関与するこ とが示唆された。腸内細菌叢は脳梗塞縮小効果をも たらす新たな治療ターゲットとなる可能性がある。 


\section{レベチラセタムによる白質病変後の認知 機能改善効果}

\begin{abstract}
1 順天堂大学医学部附属浦安病院 脳神経内科、
${ }^{2}$ 順天堂大学 医学部 脳神経内科

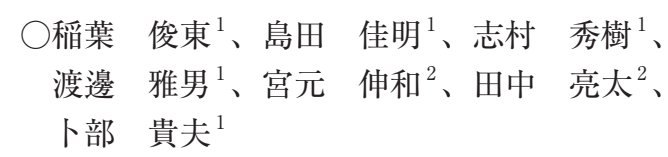

【目的】脳虚血モデルにおけるグルタミン酸の役割は、 神経細胞死を誘導することが報告されている。今回、 シナプス小胞タンパクに作用しグルタミン酸放出を 抑制する抗てんかん薬のレベチラセタム (LEV)を慢 性脳虚血モデルに用いて認知機能の改善が認められ るかを検討した。

【方法】9週齢のC57/BL6マウスの両側総澒動脈にコ イルを装着させる慢性脳低灌流モデル (BCAS model）を作製しLEVを経静脈投与した (Vehicle群 $\mathrm{n}=15$ 、 LEV 群 $\mathrm{n}=15)$ 。BCAS 作製7、14、28日後に行動 生理学的評価のためY迷路試験 $(\mathrm{n}=12)$ 、髄鞘の評 価にKB染色 $(n=6)$ 、免疫組織化学的検討 $(n=6)$ に 8-OHdG、4-HNE、GFAP、iba-1、GST-pi、PDGFR- $a$ 、 iNOS、CREB、p-CREBを行った。

【結果】Y迷路試験においてBCAS 7 日後では有意差 は認めなかったが14、28日後にてLEV群で有意な 改善を認めた $(\mathrm{P}<0.05)$ 。 KB染色では、BCAS 7 日 後では有意差を認めず、14、28日後にてLEV群で 有意な改善を認めた $(\mathrm{P}<0.05)$ 。免疫染色において BCAS 7 日後において各種陽性細胞数に有意差は認 めなかった。14、28日後では酸化ストレス、アスト ロサイト、ミクログリアの陽性細胞数がLEV群で減 少 $(\mathrm{P}<0.01)$ し、オリゴデンドロサイト前駆細胞及 びリン酸化CREBはLEV群で増加を認め $(\mathrm{P}<0.01)$ 、 GST-pi とCREBはVehicle群と有意差がなくsham群 とも変化がなかった。

【考察】LEVは、抗酸化抒よび抗炎症作用を示し、 オリゴデンドロサイト前駆細胞やリン酸化CREBを 増加させることで虚血性白質障害に伴う認知機能障 害を軽減することが明らかとなった。虚血性白質障 害へのLEVの投与は認知機能障害に保護的に作用す る可能性が示唆された。

\section{グルカゴン様ペプチド-1 効果の持続は老 化モデルマウスの認知機能障害と全身臓 器障害を軽減する}

${ }^{1}$ 熊本大学大学院生命科学研究部生体機能薬理学、
${ }^{2}$ 熊本大学大学院生命科学研究部細胞病理学

○長谷川 雄 ${ }^{1}$ 、林 建佑 ${ }^{1}$ 、岳元 裕臣 $^{1}$ 、 曹 成 ${ }^{1}$ 、林 博文 ${ }^{1}$ 、高根 紘希 ${ }^{1}$ 、 菰原 義弘 $^{2}$ 、光山 勝慶 $^{1}$

【目的】グルカゴン様ペプチド-1（GLP-1) は経口摂取 により消化管から分泌され、膵 $\beta$ 細胞からインスリ ン分泌を促進することで血糖上昇を抑制する消化管 ホルモンである。近年GLP-1が様々な臟器障害に保 護的に作用することが報告されているため、本研究 にてGLP-1効果の持続が老化に伴う認知機能障害に 対して保護効果をもつと仮説をたて、以下の検討を 行った。

【方法】GLP-1は速やかに dipeptidyl peptidase-4 (DPP-4)により代謝される。そこでGLP-1効果を持 続させるべくDPP-4 阻害薬リナグリプチンを用い、 老化モデルマウスである5 週齢のklotho遺伝子久損 (KL-/-) マウスにコントロール食(C群)またはリナ グリプチン混餌食 $(0.083 \mathrm{~g} / \mathrm{kg}$ diet ; L 群 $)$ を 4 週間投 与した。

【成績】L群では血清DPP-4活性はC群と比し1割程 度に抑制されており、GLP-1の効果が持続してい ることを確認した。4週間の経過でC群の死亡率は 33\%であったが、L群では7\%まで低下した $(\mathrm{p}=0.08) 。$ 血清インスリン濃度は2群間で差は無かったものの、 血糖値はC 群でより低値を示し、経ロブドウ糖負荷 試験に扔ける反応性はL群でより保たれているとい うパラドキシカルな結果が得られた。また、L群で はC群と比へ、受動的回避試験における再生試行の 潜時延長、脳血流増加、海馬 $\mathrm{CA} 1$ 神経細胞死の抑制 効果が認められた。その効果は脳内 $\mathrm{Akt} / \mathrm{CREB}$ の活 性化と関連した。加えてL群では老化による体重減 少や腓腹筋萎縮が抑制された。一方野生型マウスに おいて同様の検討を行い、リナグリプチン投与にて 経口ブドウ糖負荷試験に扔ける血糖上昇抑制効果や 脳血流増加を認めたが、その他はC群と差は無かっ た。

【結論】リナグリプチン長期投与によるGLP-1効果の 持続は、老化に伴う認知機能障害や全身臟器障害を 軽減し、長寿をもたらす可能性があることが示唆さ れた。 


\section{A chronic cerebral hypoperfusion model with CBF reduction and cog- nitive impairment in rats}

Department of Neurosurgery, Tohoku University Graduate School of Medicine

Mansour Ahmed、新妻 邦泰、 Rashad Sherif、藤村幹、冨永悌二

【Background】Bilateral stenosis/occlusion of common/internal carotid artery has been frequently used to mimic cognitive deficit of vascular dementia (VD). However, in these models, the cerebral blood flow (CBF) drops sharply after ligation of common carotid arteries (CCAs), which differs from 'chronic' cerebral hypoperfusion. Other modified techniques were applied by staged occlusion of both CCAs costing a longer procedure, and others used microcoils for CCA stenosis with hazardous effect on arterial endothelium. To overcome the problems described above, we developed a new model of chronic cerebral hypoperfusion $(\mathrm{CCH})$ in rats.

【Methods】 Male Sprague-Drawly rats were subjected to one side occlusion and contralateral side stenosis of CCA. Cortical regional $\mathrm{CBF}$ ( $\mathrm{rCBF}$ ) was measured using laser speckle flowmetry. The rats were assigned to $\mathrm{CCH}$ and sham operation groups. After 4 weeks, cognitive function was assessed and cervical/intracranial arteries as well as parenchymal injury were evaluated by MRI. Then rat brains were histologically evaluated.

【Results】 Gradual CBF reduction was observed in the $\mathrm{CCH}$ group. White matter degeneration noted in the copus callosum and striatum. Cellular density decreased in the hippocampus, whereas MRI revealed no cerebral infarctions. Immunohistochemistry showed inflammatory cells and angiogenesis in the hippocampus and cerebral cortex. Spatial learning and memory impairment was significantly high in the $\mathrm{CCH}$ group.

【Conclusion】 We established a new model of $\mathrm{CCH}$ in rats. The model is easy and reproducible, and may be useful to investigate $\mathrm{VD}$ and $\mathrm{CCH}$.

\section{リナグリプチンは糖尿病合併 tauopathy マウスの脳血流量を回復し認知機能を改 善させた}

${ }^{1}$ 京都大学大学院 医学研究科 臨床神経学、 ${ }^{2}$ 国立 循環器病研究センター 脳神経内科、 ${ }^{3}$ 国立循環器 病研究センター 再生医療部 $\bigcirc$ 中奥由里子 ${ }^{1,2}$ 、猪原 匡史 ${ }^{2}$ 、齊藤 聡 $^{2}$ 、
山本 由美 ${ }^{3}$ 、高橋 良輔

背景 : 2 型糖尿病はアルツハイマー病 (Alzheimer's disease : AD) を含む認知症の主要な危険因子であ る。2型糖尿病ではDPP4 阻害薬が広く使用される が、DPP4阻害によってタウのリン酸化が充進する ことがラット実験で報告されている。そこで、本研 究では認知症合併糖尿病患者へのDPP4 阻害薬投与 の有効性と安全性を検証するため、tauopathyモデ ルマウスを用いて検討した。

方法：P301S变異夕ウ過剩発現マウス (PS19)を使用 した $(\mathrm{n}=14-16 /$ 群 $)$ 。6週齢から 8 ケ歯までリナグ リプチンもしくはコントロール水とともに、高脂肪 食 $(60 \%$ 脂質、 $20 \%$ 炭水化物、20\%蛋白質)を投与し た。マウスはLaser speckle flowmetryによる脳血 流の測定後、モリスの水迷路試験を施行した。血中 の glucagon-like peptide-1を定量し、脳内のリン酸 化タウをウェスタンブロッティングと免疫組織化学 法で半定量した。

結果：PS19マウスへの高脂肪食の投与によって、 コントロール水投与群で血糖值は上昇したが、リナ グリプチンの投与により抑制された。また、リナグ リプチン投与群では血中 glucagon-like peptide-1濃 度が上昇していた。リナグリプチン群ではリン酸化 タウ量に有意な変化は見られなかったが、脳血流量 が有意に増加していた。両群の運動能力に有意な差 異は見られないものの、リナグリプチン群でコント ロール群に比して視空間記憶障害の有意な改善が認 められた。

結論：リナグリプチンは脳内のリン酸化タウを増加 させることなく高脂肪食投与PS19マウスの認知機 能を改善させた。認知症合併糖尿病患者へのDPP4 阻害薬の投与は脳血流増加および認知機能改善の点 においては有効であると考えられた。 


\section{慢性脳低灌流はタウ病理を加速させる： 脳血管アミロイド血管症とタウとの関連}

${ }^{1}$ 国立循環器病研究センター 脳神経内科、 ${ }^{2}$ 国立循 環器病研究センター 再生医療部、 ${ }^{3}$ 京都大学大学 院医学研究科 臨床神経学

$\bigcirc$ 齊藤 聡 $^{1,2,3}$ 、山本 由美 ${ }^{2}$ 、高橋 良輔 $^{3}$ 、 猪原 匡史 ${ }^{1}$

【目的】我々は以前、脳アミロイド血管症 (cerebral amyloid angiopathy：CAA）と密接に関連するそ血 や虚血が $\mathrm{A} \beta$ 沈着を促進させることを報告した。一 方タウは、GSK-3 $\beta$ 等によるリン酸化によってその 凝集性が立進するが、GSK-3 $\beta$ は低酸素によって活 性が立進することが知られている。今回我々は、慢 性脳低灌流やCAAが夕ウ病理に与える影響を検討 し、脳血管を標的としたタウ病理改善の可能性につ いて検討した。

【方法】3 ケ月齢の野生型マウスおよびP301S変異夕 ウ過剩発現マウス (PS19)の右総頸䅡動脈を結紮し て慢性脳低灌流を誘導し、左右の海馬のリン酸化 タウの蓄積を病理学的に解析した。さらに、PS19 マウスとCAAモデルマウス $(\mathrm{Tg}-\mathrm{SwDI})$ を交配させ、 ダブルトランスジェニックマウス (double-Tg)を作 成し、CAA、慢性脳低灌流、夕ウ病理の関連を検 討した。

【結果】右総頸動脈を結紮したマウスでは、手術 5 ケ 月後においても閉塞側の脳血流量は非閉塞側の約 90\%であり、慢性脳低灌流が確認された。PS19マ ウスの海馬では、非閉塞側に比して閉塞側で、夕ウ のリン酸化が有意に立進していた。脳血流量の低下 はTg-SwDIマウスとPS19マウスを交配させたdouble-Tgマウスでも確認された。double-Tgマウスで は、Tg-SwDIマウスやPS19マウスに比して、A $\beta$ の 沈着や夕ウのリン酸化が充進しており、加えて神経 細胞脱落およびastrocyteやmicrogliaの活性化が認 められた。行動試験においても、double-Tgマウス では、不安行動の異常や視空間記憶障害が増悪して いた。

【結語】慢性脳低灌流はタウのリン酸化を促進させた。 慢性脳低灌流やCAAへの治療介入は夕ウ病理や神 経細胞脱落にも有効である可能性が示唆された。

\section{$\mathrm{Na}^{+}, \mathrm{K}^{+}$-ATPase $\alpha$ 2サブユニット遺伝子 欠損マウスにおける皮質拡延性抑制に対 する感受性と脳内c-Fos発現分布}

${ }^{1}$ 慶應義塾大学 医学部 神経内科、 ${ }^{2}$ 国際医療福祉 大学 生理学、 ${ }^{3}$ 自治医科大学 分子病態治療研究七 ンター 細胞生物研究部

○畧川美悠紀 ${ }^{1}$ 、池田 啓子 ${ }^{2,3}$ 、冨田 裕 ${ }^{1}$ 、 川上 潔 ${ }^{3}$ 、鈴木 則宏 $^{1}$

【目的】単一遺伝子異常に起因する家族性片麻疩性片 頭痛 $(\mathrm{FHM})$ にはいくつかの病型が知られており、2 型(FHM2)では $\mathrm{Na}^{+}, \mathrm{K}^{+}$-ATPase $\alpha 2$ サブユニットを コードするATP1A2領域に異常が見られる。本研 究では、Atp1a2欠損マウスを用い、片頭痛の前兆 に重要な大脳皮質拡延性抑制 (CSD) に対する感受性 と反応性および脳内のc-Fos発現分布について検討 した。

【方法】Atp1a2領域のN末端側 (NKO) あるいはC末 端側 $(\mathrm{CKO})$ を欠損させた 2 種類の雄性へテロ欠損 (HT) および同腹の野生型 (WT) マウスをウレタン で麻酔して人工呼吸を施し、DC電位、局所脳血流 (CBF) を記録した。(1) 後方の骨空から濃度の異な る KCl溶液を $0.025 \mathrm{M}$ から順に滴下し、初めてCSDを 発生する濃度をCSD発生閯值とし、発生したCSDの 電気的特性、伝播速度を算出した (各群 $\mathrm{n}=11 \sim 12)$ 。 (2) 片側に0.3Mの KCl溶液 $5 \mu \mathrm{l}$ を滴下して $5 \sim 6$ 回の CSDを発生させ、2時間後に脳を摘出し、全脳にお いて免疫組織化学的にc-Fos発現分布を計測した(各 群 $\mathrm{n}=5$ および擬手術C57BL/6J n=5)。

【結果】(1) NKOにおいて、HTではWTに比べて低 濃度の $\mathrm{KCl}$ でCSDが発生した $(0.12$ vs $0.15 \mathrm{M} ; \mathrm{p}<$ 0.01)。DC電位の低下量に有意差はなかったが、回 復に要する時間を示す半值幅 (52 vs 41 秒; p $<$ 0.01)、CSD伝播速度は高值であった( 4.2 vs $3.4 \mathrm{~mm}$ ) 分 $; \mathrm{p}<0.01)$ 。 CSD発生時の脳波は強く抑制された $(-43 \mathrm{vs}-32 \% ; \mathrm{p}<0.01)$ 。これらの差異は、いずれ もCKOより顕著であった。CSDに伴うCBFの変化 は遺伝子型による有意差は認められなかった。(2) 一側にCSDを誘発すると、同側大脳皮質だけでなく、 同側線条体、梨状皮質、扁桃体および両側三叉神経 脊髄路核においてc-Fosの発現増強が観察された。

【結語】Atp1a2欠損マウスを用いた本実験結果から、 CSDに対する感受性が高いことが片頭痛と関連する 可能性が示唆され、遺伝子欠損部位によって感受性 や反応性に差があることが示された。 